Ph.D értekezés

\title{
FOTOELEKTROMOS JELENSÉGEK \\ REAKCIÓCENTRUM FEHÉRJE-NANOHIBRID \\ RENDSZEREKBEN
}

Szabó Tibor

Témavezető: Dr. Nagy László, egyetemi docens

Szegedi Tudományegyetem

Orvosi Fizikai és Orvosi Informatikai Intézet

Fizika Doktori Iskola

Szeged, 2018 


\section{Tartalomjegyzék}

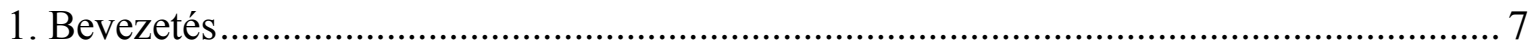

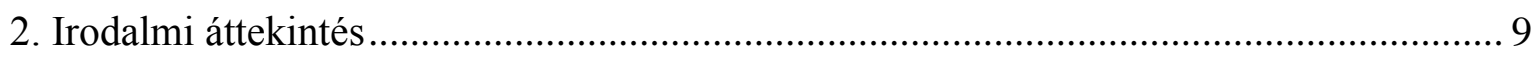

2.1. Fotoszintézis az alapkutatásban ....................................................... 9

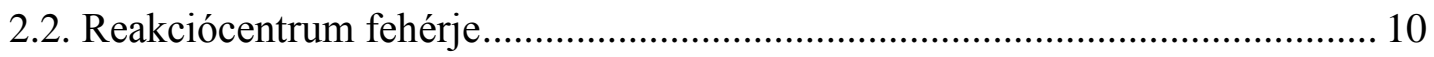

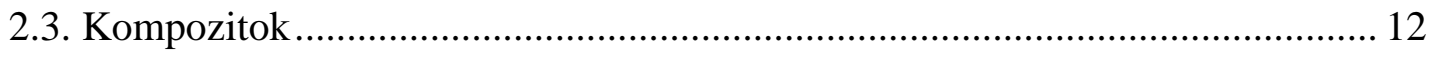

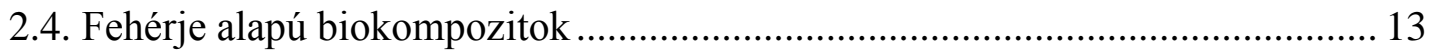

2.5. Fotoszintetikus reakciócentrum fehérje mesterséges környezetben.................. 14

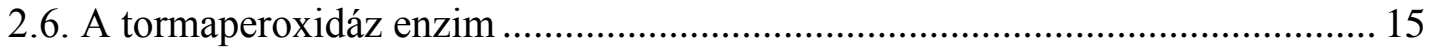

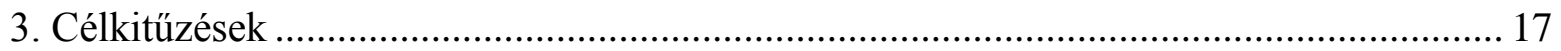

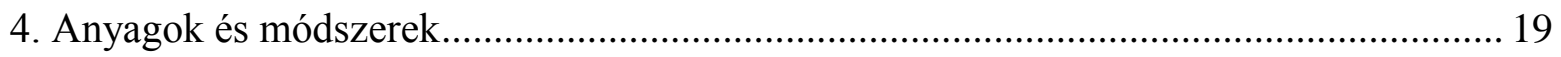

4.1. Preparatív eljárások ........................................................................... 19

4.1.1. Rekciócentrum preparálása...................................................... 19

4.1.2. ITO/RC kompozit előállítása .................................................... 19

4.1.3. Szén nanocsövek előállítása ...................................................... 20

4.1.4. RC rögzítése szén nanocső felületén ........................................... 21

4.1.5. RC rögzítése vezető polimeren keresztül ...................................... 23

4.1.6. RC vezető polimer rétegstruktúrában .............................................. 24

4.1.6 Példa egyéb fehérje alkalmazására: Tormaperoxidáz enzim ............... 26

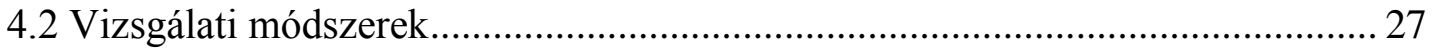


4.2.1. Képalkotó eljárások ............................................................................ 27

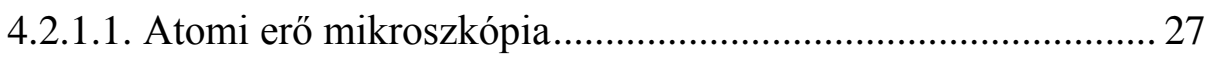

4.2.1.2. Transzmissziós elektronmikroszkópia …………………...... 27

4.2.2. Spektroszkópiai módszerek.............................................................. 28

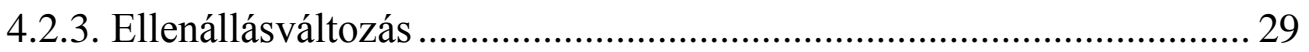



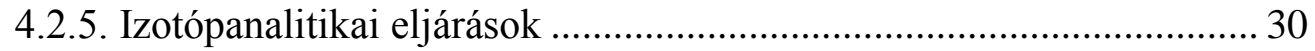

4.2.5.1. Szénizotóp tartalom meghatározása .......................................... 30

4.2.5.2. Stabilizotóp mérések ............................................................... 32

4.2.5.3. Kéntartalom meghatározása ................................................... 32

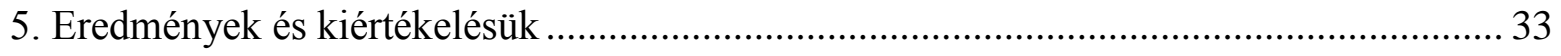

5.1. ITO és ITO/RC kompozit strukturális jellemzése ............................................... 33

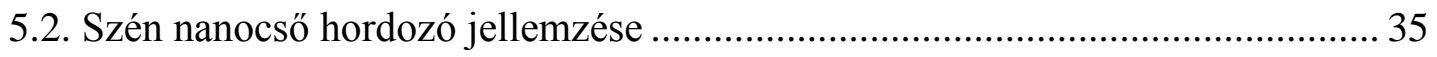

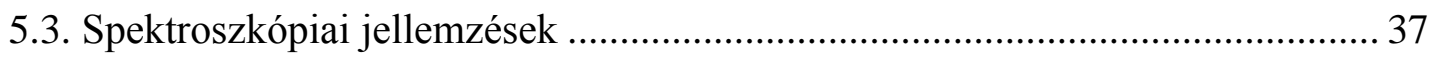

5.3.1. Egyensúlyi abszorpciós spektroszkópia ............................................. 37

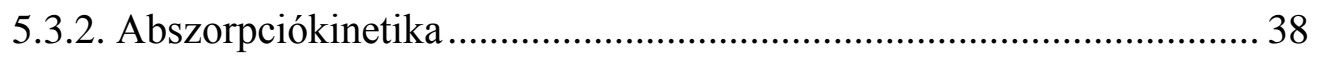

5.4. Elektromos mérések ITO/RC kompoziton ....................................................... 41

5.5. ITO/MWCNT/RC fotokémiája elektrokémiai cellában ....................................... 43

5.6. ITO/MWCNT/PTAA/RC fotokémiája elektrokémiai cellában ........................... 46

5.7. Fotoáram keltése RC-mal érzékenyített vezető polimer rétegstruktúrában ........ 47

5.8. Szén nanocsövek izotópanalitikai jellemzése ..................................................... 51 
5.8.1. Stabilizotóp tartalom karakterizálása .

5.8.2. Szénizotóp tartalom karakterizálása ............................................. 55

5.9. MWCNT/RC kompozit izotópanalitikai jellemzése .................................... 56

5.10. MWCNT/HRP kompozit izotópanalitikai jellemzése.................................. 58

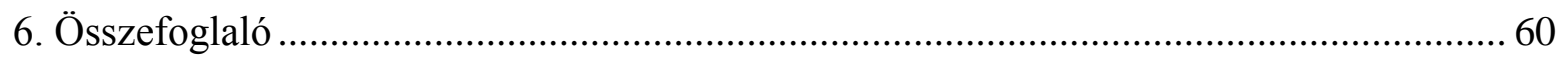

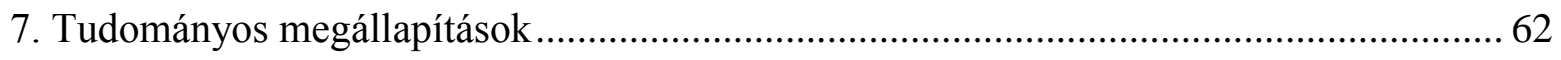

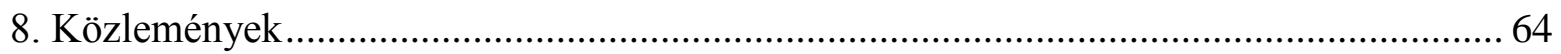

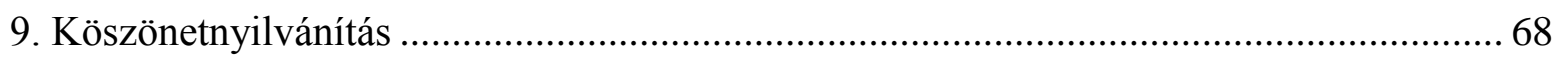

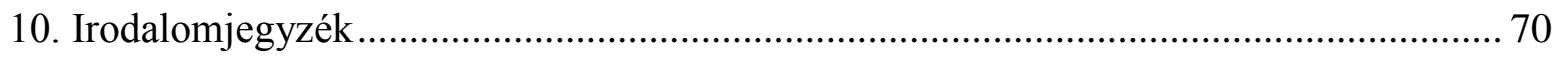

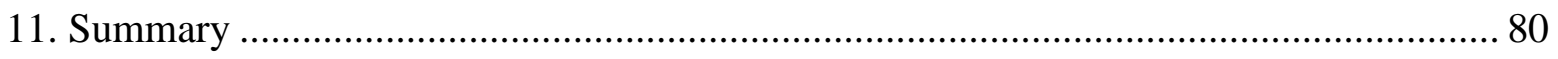




\section{Rövidítések jegyzéke}

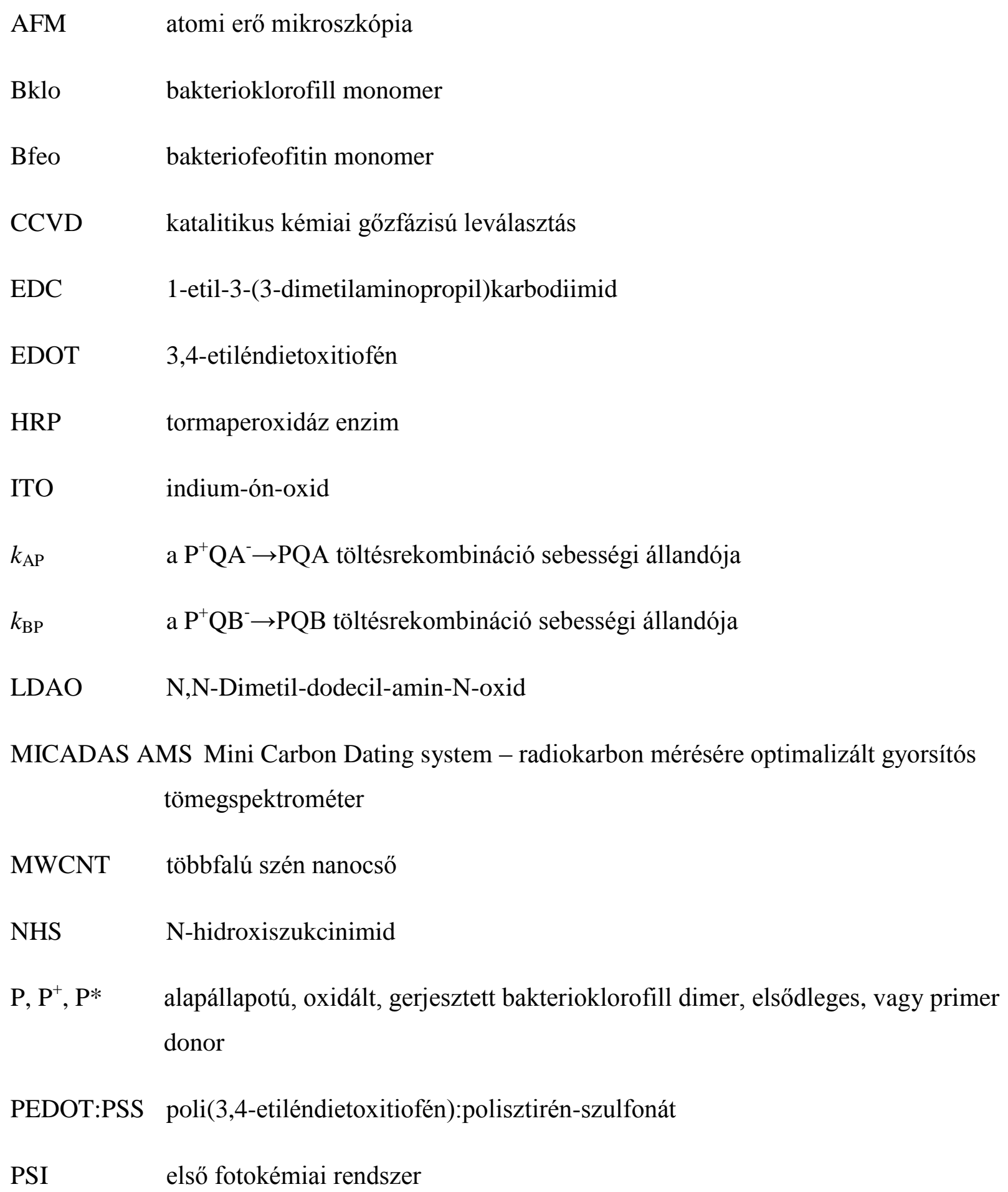




$\begin{array}{ll}\text { PSII } & \text { második fotokémiai rendszer } \\ \text { PTAA } & \text { poli(3-tiofén ecetsav) } \\ \text { P3HT } & \text { poli-3-hexiltiofén } \\ \mathrm{Q}_{\mathrm{A}} & \text { elsődleges vagy primer kinon, } \\ \mathrm{Q}_{\mathrm{B}} & \text { másodlagos vagy szekunder kinon } \\ \mathrm{QH}_{2} & \text { dihidro-kinon, kinol } \\ \mathrm{RC} & \text { reakciócentrum fehérje } \\ \text { TEM } & \text { transzmissziós elektronmikroszkópia } \\ \text { TRIS } & \text { Trisz-(hidroximetil)-amino-metán } \\ \text { UQ } & \text { ubikinon-10, 2,3-dimetoxi-5-metil-6-kaizoprenol-p-benzokinon }\end{array}$




\section{Bevezetés}

A fotoszintézis az élőlények egyik legalapvetőbb anyagcsere folyamata, ezért már évtizedek óta mind az alap-, mind az alkalmazott kutatások fókuszában van. Igen részletesen ismerjük a fényelnyelést követő energiavándorlás, töltésszétválasztás és -stabilizálódás mechanizmusát, az elektron- és protontranszport folyamatokat. Hasonlóképpen bőséges ismerettel rendelkezünk a kémiai potenciál kialakulásáról és az ehhez kapcsolódó ATP-szintézis folyamatáról, az ezekhez kapcsolódó struktúrákról és szerkezet-funkció kapcsolatokról. Az eddig felhalmozott tudás inherensen hozta magával annak az igényét, de lehetőséget is teremtett arra, hogy az élő rendszerekben lejátszódó folyamatokat mesterséges (ún. biosimilar/-mimiking) rendszerekben lemásoljuk, utánozzuk. A biológiai rendszerek, a jellemző molekuláik (fehérjék, nukleinsavak) az evolúciós folyamatok során képessé váltak adott feladatok nagyon specifikus és nagy hatékonyságú elvégzésére. Adódik tehát a lehetőség, hogy ezeket a jól müködő rendszereket, vagy azok részeit általunk alkotott eszközökbe építve alkalmazzuk. Továbbá, a biológiai rendszerek megismerése modellként szolgálhat egyéb rendszerek tervezéséhez és megalkotásához.

Ahhoz, hogy a biológiai anyagok specifikus tulajdonságait általunk alkotott eszközökben kamatoztatni tudjuk, olyan környezetet kell teremteni számukra, ahol aktivitásukat továbbra is megőrzik. Lehetőségként adódik kompozit anyagok létrehozása, melyekben az aktív komponenst a biológiai anyag, a hordozó szerepét pedig egy másik szerves, vagy akár szervetlen anyag képezi.

A nanoanyagok napjainkban szintén a tudomány érdeklődési tárgyát képezik, számos, a tömbi fázistól eltérő előnyös tulajdonságuk miatt. Ilyen széles körben kutatott és napjainkban már számos helyen alkalmazott anyagok például a szén módosulatai, a különböző szén nanocsövek és a grafén, vagy különböző nanométeres tartományba eső fém vagy fém-oxid részecskék. A nanoanyagok elönyös tulajdonságai, úgymint a nagy fajlagos felület, vagy a speciális optikai tulajdonságok kiaknázhatóak kompozit anyagok készítése során. 
Nanoanyagok és biológiai eredetü anyagok kombinálásával úgynevezett bionanokompozit anyagok készíthetök, melyeket a jövő anyagainak is neveznek. Alkalmazhatóságuk igen széles körü, bionanokompozit anyagokat alkalmaznak a napenergia hasznosításban, fotodetektorként, fototranzisztorként, herbicid szenzorokként, üzemanyag cellákban és egyéb optoelektronikai alkalmazásokban. Külön kiemelendő, hogy az orvostudomány területén is nagy jelentőséggel bírnak, hiszen a különböző rekonstrukciós eljárások esetén nem mindig van lehetőség emberi szövettel pótolni a sérült vagy esetlegesen hiányzó szöveti részeket. Ilyen esetekben mesterséges anyagok használatára kényszerülünk, melyeknek alapvető követelménye, hogy biokompatibilisek legyenek, így a bio- és szervetlen anyagok kapcsolatának a tanulmányozása kiemelt jelentőségü.

A Szegedi Tudományegyetem Orvosi Fizikai és Orvosi Informatikai Intézetében nagy hagyománya van a fotoszintézis kutatásának, azon belül is a bakteriális rendszerek tanulmányozásának. A bakteriális fotoszintézis első lépései a reakciócentrum fehérjében játszódnak le, amely a primer töltésszétválasztásért és töltésstabilizálódásért felelős, ezzel megalapozva a fényenergia átalakítását. A Dr. Nagy László vezette Nano-bionika kutatócsoport fehérjék (főként bíborbaktériumokból preparált fotoszintetikus reakciócentrum fehérje - RC) bionanokompozitokba építésével és tulajdonságaik karakterizálásával foglalkozik. Kutatómunkámat a Nano-bionika csoportban végeztem. Munkám során Rhodobacter sphaeroides R26 bíborbaktériumból kinyert bakteriális reakciócentrum fehérjét alkalmaztam mesterségesen előállított bionanorendszerek kialakítására. A RC fehérjén megszerzett tapasztalatainkat más, föképp redox-fehérjét alkalmazó nanorendszerekre is megpróbálhatjuk alkalmazni, ezt a tormaperoxidáz enzim alapú kompozit példáján mutatom be. 


\section{Irodalmi áttekintés}

\subsection{Fotoszintézis az alapkutatásban}

Nem túlzás azt mondani, hogy a fotoszintézis Földünk egyik legmeghatározóbb folyamata, mely nélkül a föld jelenlegi formája nem alakulhatott volna ki, valamint a fenntarthatóságában is meghatározó a szerepe. Mind az oxigéndús légkör, mind táplálékaink jelentős része és a jelenleg is legfontosabb energiahordozóink is a fotoszintézis termékei, melyek alapvetően határozzák meg létünket. A fotoszintézisre a növények mellett algák és fotoszintetizáló baktériumok is képesek. A növényekben, algákban és cianobaktériumokban úgynevezett oxigenikus fotoszintézis játszódik le, mely során a víz elbontásából származó elektron széndioxid redukálására, majd szerves vegyületek előállítására használódik, majd a folyamat melléktermékeként molekuláris oxigén szabadul fel. Anoxigenikus esetben nem a víz, hanem egyéb szerves vagy szervetlen anyagok szolgálnak elektronforrásul a fotoszintetikus baktériumoknak. A fotoszintetizáló baktériumokat 6 törzsbe soroljuk, úgymint cianobaktériumok, bíborbaktériumok, zöld kén baktériumok, zöld nem kén baktériumok, heliobaktériumok és acidobaktériumok [Blankenship 2010, Raymond és Blankenship 2008], melyek közül csak a cianobaktériumok folytatnak oxigenikus fotoszintézist.

A fotoszintézis során a fotofizikai, -kémiai és elektrontranszport folyamatok jelentős része membránhoz kötötten valósul meg. A legtöbb fotoszintetizálásra képes rendszer esetén ez egy speciális membránba ágyazódva, a tilakoidmembránban játszódik le [Vothknecht és Westhoff 2001]. Prokarióta szervezetek esetén a citoplazmamembrán szolgál a fotoszintézis fényhez közvetlenül kapcsolódó folyamatainak színhelyéül [Bína és mtsai. 2014]. A fotoszintézis első lépéseként egy foton hatására közvetlenül, vagy antennarendszerek közvetítésével, töltéspár keletkezik egy transzmembránfehérjén belül. A növények esetében ezt a fehérjét az első és második fotokémiai rendszernek (PSI és PSII), baktériumok esetén pedig reakciócentrum fehérjének nevezzük. Bizonyos baktériumok (pl. bíborbaktériumok) reakciócentruma az első 
fotokémiai rendszerrel, mások (pl. zöld kén baktériumok) reakciócentruma a második fotokémiai rendszerrel mutat analógiát (1. ábra).

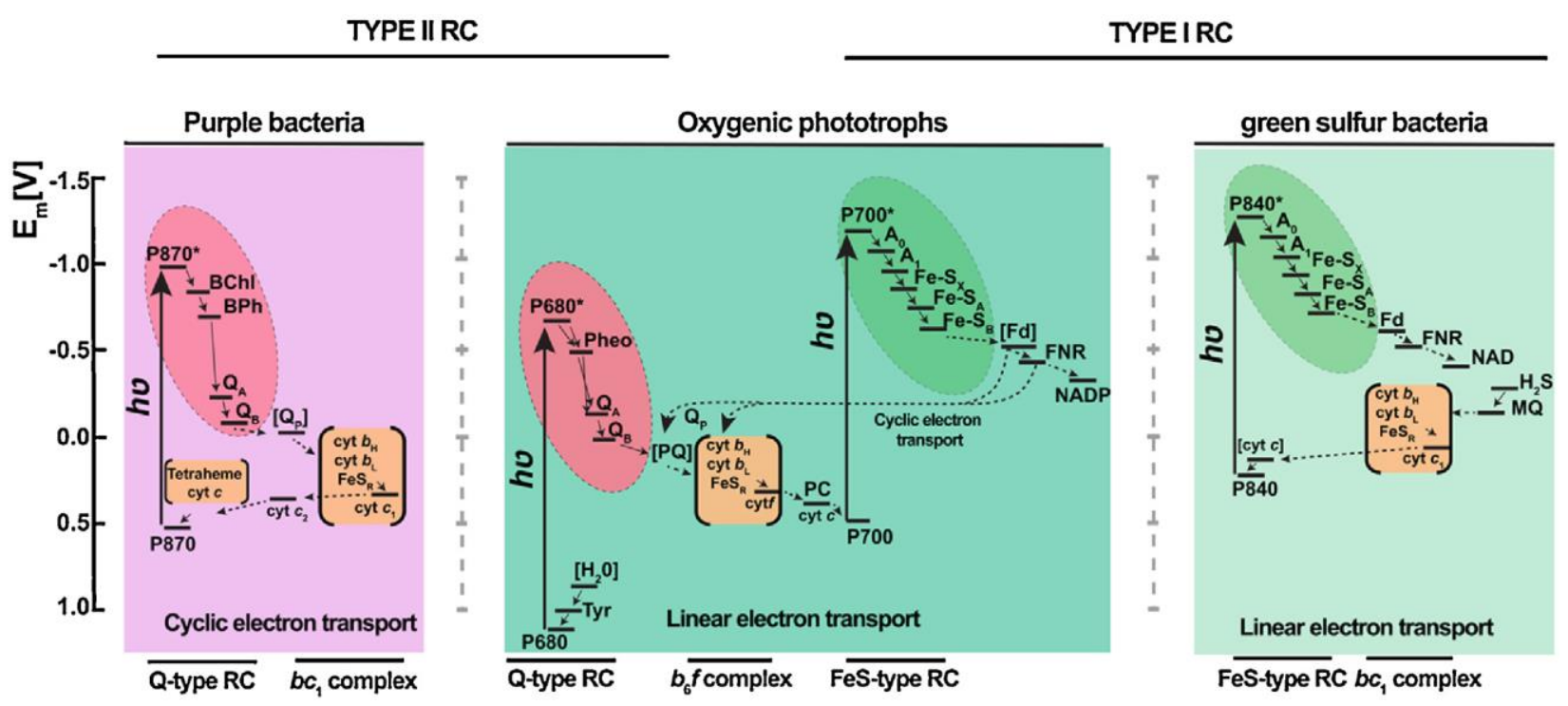

1. ábra

A PSI és PSII, valamint a bíbor és zöld kénbaktériumok reakciócentrum fehérjéin belüli elektrontranszport összehasonlítása [Musazade és mtsai. 2018]

\subsection{Reakciócentrum fehérje}

A reakciócentrum egy membránba ágyazott pigment-protein komplex. A fehérjevázat három alegység alkotja ( $\mathrm{H}, \mathrm{L}$ és $\mathrm{M})$, melybe ágyazva kofaktorok helyezkednek el (2. ábra). A kofaktorok a fehérjén belül szimmetrikusan helyezkednek el, de csak az egyik ág vesz részt az elektrontranszportban. A primer elektrondonor egy bakterioklorofill dimer (BChl), mely egy foton vagy gerjesztési energia elnyelödését követően gerjesztett állapotba kerül, és egy elektront juttat a másodlagos kinonra $\left(\mathrm{Q}_{\mathrm{B}}\right)$ egy bakteriofeofitinen (BPheo) és az elsődleges kinonon $\left(\mathrm{Q}_{\mathrm{A}}\right)$ keresztül. $\mathrm{A} \mathrm{Q}_{\mathrm{B}}$ két elektron és két proton felvételét követően leválik a fehérjéröl és töltéseket továbbít a membránban diffundálva a citokróm $b c_{1}$ felé. A primer donor elektronhiányát egy citokróm $\mathrm{c}_{2}$ molekula pótolja, ezáltal ciklikussá téve a folyamatot (3. ábra). Az élő rendszerből 
izolált, tisztított RC-ban is bekövetkeznek ezek a folyamatok, és a fehérjén belül fényelnyelés hatására stabil töltéspár keletkezhet. Az élő rendszerben lejátszódó folyamatos müködést a bakterioklorofillhoz kapcsolódó másodlagos donor és a kinon-akceptor komplexhez kapcsolódó másodlagos elektronakceptor rendszerekkel mesterséges környezetben, ún. hibrid rendszereken is biztosítani lehet.

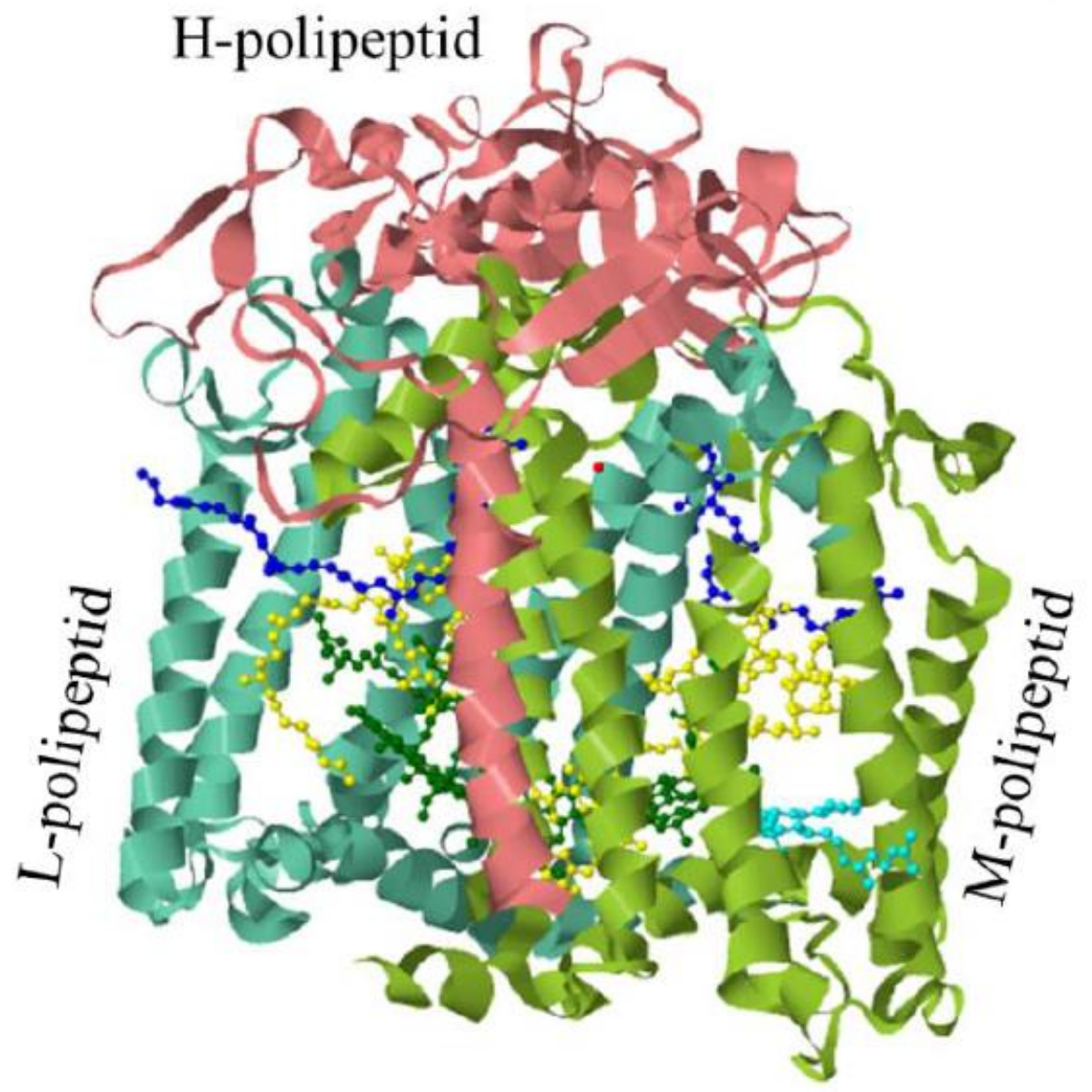

2. ábra

A Rhodobacter sphaeroides reakciócentrum fehérje szerkezete a kofaktorokkal. Az alegységeket különböző színnel jelöltem (H piros, L türkisz, M zöld). A kofaktorokat gömbök jelölik: Bklo, zöld gömb; Bfeo, sárga gömb; kinon, kék gömb; karotenoid, türkiz kék gömb és a vasatom piros gömb. Az ábra a brookhaveni Protein Data Bank (www.rcsb.org) 1PST.pdb adatállománya alapján JSmol programmal készült [Magyar 2015]. 


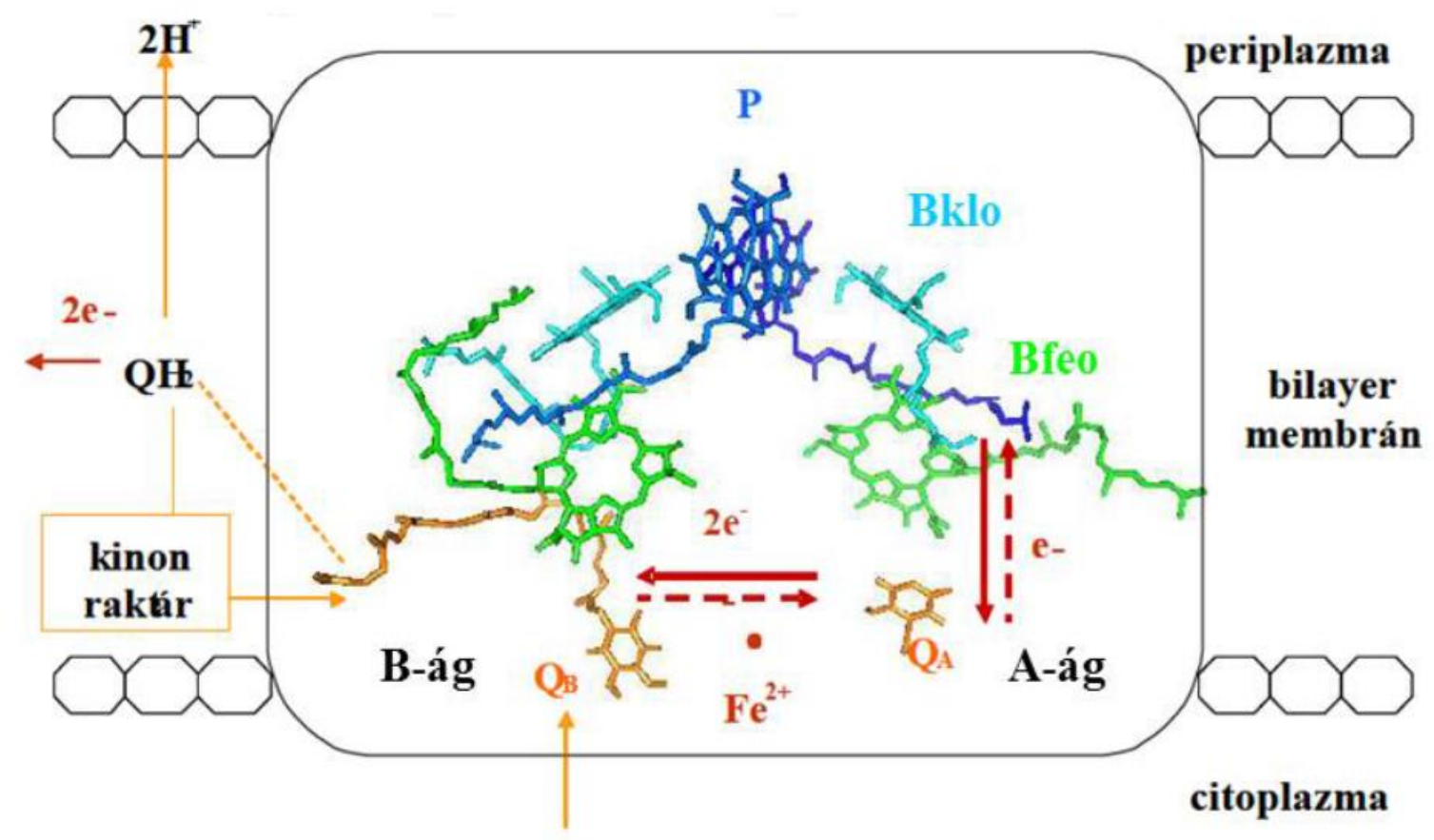

$2 \mathbf{H}^{+}$

3. ábra

A kofaktorok elrendeződése a RC-on belül. A jobb láthatóság érdekében a fehérjevázat nem tüntetem fel. A piros nyilak az elektron útját, a sárga nyilak pedig a protonációs folyamatokat jelölik. A szaggatott nyilak a rekombinációs folyamatok irányát mutatják [Rinyu 2007].

\subsection{Kompozitok}

Kompozit anyagoknak azokat az anyagokat nevezzük, melyek kettő vagy több különbözö fizikai és kémiai tulajdonságokkal rendelkező anyagból épülnek fel. Az anyagok kombinációjával elérhetjük, hogy egymás elönyös tulajdonságait erősítsék, de akár új hasznos jellemzők is kialakulhatnak. Ezen anyagok egy csoportját alkotják a nanokompozit anyagok, melyek esetén legalább az egyik alkotó, legalább egyik dimenzióját tekintve nanométeres nagyságrendbe esik. A 
nanoanyagokat nagyon magas felület/térfogat arány jellemzi, ami miatt alapvetően eltérő tulajdonságokat mutatnak a tömbi fázisú anyagokhoz képest.

Bionanokompozit anyagokról akkor beszélhetünk, ha valamelyik komponenst biológiai eredetü anyag alkotja. A biokompozit anyagokban általában a „bio komponens” az aktív elem. Ez a komponens számos biológiai eredetű anyag lehet, egész sejt, vagy annak egy része, fehérje, antitest, antigén, de akár egy RNS vagy DNS szekvencia is.

A biokompozit másik komponense legtöbb esetben a hordozó szerepét tölti be. Erre a célra számos, általában szervetlen anyag használható, például fémek, fém oxidok vagy a különböző félvezető anyagok. A bio komponens részarányának növelésével előtérbe kerülnek a kis részecskeméretü, nagy fajlagos felületü anyagok. Ilyenek lehetnek a porózus anyagok, a nanoméretü részecskék, nanocsövek és nanoszálak.

\subsection{Fehérje alapú biokompozitok}

Számos példa van arra az irodalomban is, hogy biológiai anyagok (biomolekulák, sejtalkotók, sejtek, szövetek, stb.) élő szervezetből történő izolálásuk után, mesterséges környezetben is nagymértékben megőrzik aktivitásukat. Az evolúciós folyamatoknak köszönhetően ezek a rendszerek specifikus feladataikat kiválóan látják el, rendkívül érzékenyek, így adódik a lehetőség ezek közvetlen felhasználására, vagy modellrendszerként történő alkalmazására. A fehérjék bio-hibrid rendszerekben történő alkalmazásának is több lehetőségét találhatjuk az irodalomban. Az enzimfehérjék nagy specificitása és hatékonysága különös alkalmazási lehetőséget ad a bioszenzorika területén [Hayashi és mtsai., 2002, Scognamiglio és mtsai., 2013, Ozdokur és mtsai., 2014, Jiang és mtsai., 2012]. A fényérzékeny fehérjéket (fotoszintetikus fehérjék, bakteriorodopszin) az energiaátalakítás kivételesen nagy hatásfoka (közel 100\% kvatumhatásfok (Wraight and Clayton, 1974), de adott esetben ezt megközelítő energiahatásfok is) miatt integrált optikai rendszerekben (pl. logikai kapcsolókban, információtovábbításban (Fábián és mtsai., 2011, Dér és mtsai., 2007, Vsevolodov, 1998)), fotonikai struktúrákban (Hajdu és mtsai., 2012a,b, Estephan és mtsai., 2011, Paestino és mtsai., 
2008) próbálják alkalmazni. Éppen a kivételesen magas energiaátalakító hatásfokuk miatt a fotoszintetikus fehérjék fotovoltaikában, napenergiahasznosításban betöltött szerepe is intenzíven kutatott terület (1. részletesebben a következő fejezetben). Amikor bio-nanohibrid rendszerekről beszélünk, két fontos szempontot kell még megemlítenünk. A biomolekulák szervetlen anyagokkal való kölcsönhatásainak köszönhetően kiváló modellek, hasznos információval szolgálhatnak az élő szervezetbe bekerült/bejuttatott (implantált) anyagok stabilitásával kapcsolatosan. Külön kiemelendő az is, hogy ezek megújuló rendszerek, az ember alkotta eszközökkel ellentétben a kialakult folyamatok során lebomlanak és újrahasznosulnak, nem szennyezik a környezetünket.

\subsection{Fotoszintetikus reakciócentrum fehérje mesterséges környezetben}

A fotoszintetikus reakciócentrum fehérjében fényelnyelést követően töltéspár keletkezik, amely normál körülmények között a kémiai potenciál kialakításában vesz részt. A reakciócentrum fehérje mesterséges környezetben, különböző szervetlen hordozókhoz kapcsolódva is nagy mértékben megőrzi aktivitását, fénnyel való gerjesztés hatására fotoáramot generál amit számos a közelmúltban megjelent tanulmány is hangsúlyoz [pl. Frolov és mtsai., 2008, Kamran és mtsai., 2014, Zhao és mtsai., 2002, Hollander és mtsai., 2011, Das és mtsai., 2004, Lués mtsai., 2007, Tan és mtsai., 2012].

A legkülönfélébb RC komplexek alkalmazását írták már le, a növények első és második fotokémai rendszerétől a baktériumok reakciócentrumáig, fénybegyűjtő antennakomplexekkel, vagy anélkül (Lásd pl. Noji és mtsai., 2011, Oda és mtsai., 2006, Hollander és mtsai., 2011, Kamran és mtsai., 2014, Giraldo és mtsai., 2014, Carmeli és mtsai., 2007, stb.), de számos kérdés még megválaszolatlanul maradt, melyek közül néhányat a jelen dolgozatban igyekszek megválaszolni.

Mint a legtöbb biokompozit esetében, a RC-mal készített kompozitoknál is a szerkezeti és müködési stabilitás megtartása jelenti a nehézséget. A PSII a legérzékenyebb a stabilitásra, de a baktériumok RC-ából készült kompozitok hetekig, akár néhány hónapig is megőrzik 
stabilitásukat szobahőmérsékleten, $4{ }^{\circ} \mathrm{C}$-on még tovább is (Magyar és mtsai., 2011, Dorogi és mtsai., 2006). A RC fehérjének ez a kivételes tulajdonsága lehetőséget teremt egyéb felhasználásra is, úgymint a napenergia hasznosítás [Tan és mtsai., 2012, den Hollander és mtsai., 2011], fotodetektorok [Govorov és mtsai., 2007, Terasaki és mtsai., 2007, Frolov és mtasi., 2008, Nishihara és mtsai. 2007], fototranzisztorok [Terasaki és mtsai., 2007, Frolov és mtsai., 2008], herbicid szenzorok [Ventrella és mtsai., 2010, Giardi és mtsai., 2006, Giardi és mtsai., 2009, Szabó és mtsai., 2016, Guascito és mtsai., 2016, Swainsbury és mtsai., 2014, Chatzipetrou és mtsai,. 2016, Nakamura és mtsai., 2003], üzemanyag cellák [Krassen és mtsai., 2009] készítése és egyéb optoelektronikai alkalmazások [Kaniber és mtsai., 2009, Sepunaru és mtsai., 2009, Dimonte és mtsai., 2012].

\subsection{A tormaperoxidáz enzim}

A tormaperoxidáz enzim (HRP) a torma (Amoratia rusticana) gyökerében termelődő vastartalmú hemoprotein, melynek molekulatömege $44 \mathrm{kDa}$ (4. ábra). A fehérje aktív egysége egy hem-típusú prosztetikus csoport, mely egy vasatomot tartalmazó porfiringyürü. A HRP katalitikus reakció során elektrondonor jelenlétében képes a hidrogénperoxid $\left(\mathrm{H}_{2} \mathrm{O}_{2}\right)$ vízzé alakítására.

A HRP széles körben alkalmazott fehérje, használják immunteszteknél [Song és mtsai., 2010, Krieg és Halbhuber 2003] toxikus vegyületek elbontására [Silva és mtsai., 2010], tumor terápiában [Folkes és Wardman 2001; Greco és mtsai., 2001, Wardman 2002], szennyvízkezelés [Veitch 2004] vagy akár $\mathrm{H}_{2} \mathrm{O}_{2}$ bioszenzorokként [Magyar és mtsai., 2013] is. 


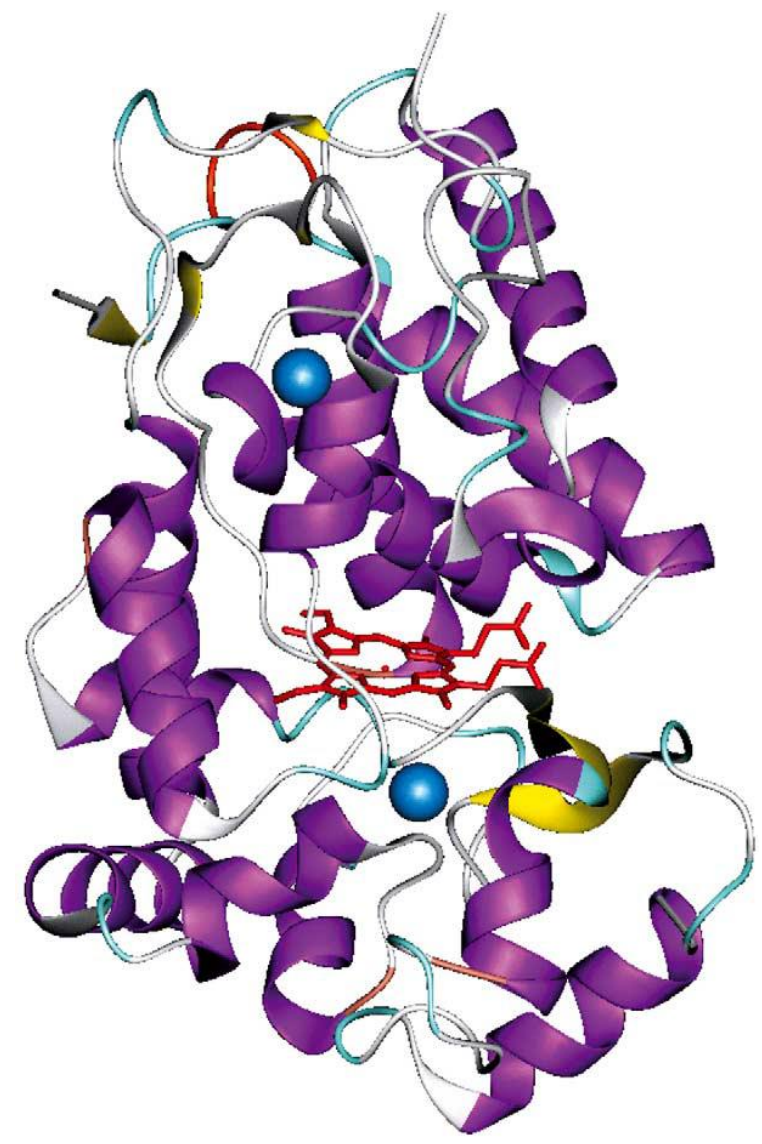

4. ábra

A HRP molekulaszerkezete. A fehérjeváz közepén helyezkedik el a hemcsoport (piros), a kék gömbök kálciumatomokat jelölnek. A fehérjén belül az $\alpha$ hélix szerkezetek lila, míg a $\beta$ redő struktúrák sárga színnel szerepelnek. Az ábrát a brookhaveni Protein Data Bank (www.rcsb.org) 1H5A.pdb adatállomány alapján készült [Veitch 2004]. 


\section{Célkitüzések}

A Szegedi Tudományegyetem Orvosi Fizikai és Orvosi Informatikai Intézetében nagy hagyománya van a fotoszintézis kutatásának, azon belül is a bakteriális rendszerek tanulmányozásának. A bakteriális fotoszintézis első lépéseit a reakciócentrum fehérje végzi, amely a primer töltésszétválasztásért felelős, ezzel megalapozva a fényenergia átalakítását. A fotoszintézis kutatás, mint alapkutatás is igen nagy jelentőséggel bír és a témában megszerzett tudás lehetőséget ad a természettől tanulva hatékony mesterséges rendszerek létrehozására. Munkám során fotoszintetizáló bíborbaktériumból kinyert bakteriális reakciócentrum fehérjét alkalmaztam mesterségesen előállított bionanorendszerek kialakítására. Az így megszerzett tudás egyéb fehérjét alkalmazó nanorendszerekre is átültethető, melyet egy tormaperoxidáz enzim alapú kompozit példáján mutatok be.

Ezeknek megfelelően a munkám során célul tüztem ki:

1. ITO-ból és RC-ból kompozit anyag létrehozását és ennek spektroszkópiai és elektromos tulajdonságainak karakterizálását száraz körülménye között.

2. Fénnyel gerjeszthető vezető polimer rétegstruktúra (PEDOT:PSS, P3HT) létrehozását ITO és ezüst elektródok alkalmazásával, továbbá a kialakított struktúra RC-mal való érzékenyítését, valamint a minta spektroszkópiai és fotoelektromos tulajdonságainak karakterizálását, a fehérje érzékenyítő tulajdonságának kimutatását.

3. Egy háromelektródos elektrokémiai cella kialakítását, melynek munkaelektródját ITO/MWCNT/RC kompozit, ellen és referencia elektródját pedig platina és $\mathrm{Ag} / \mathrm{AgCl}$ alkotja. A rendszerrel fotoáram generálását, továbbá mediátorok fotoáramra való hatásának kimutatását.

4. Az előbbi pontban már ismertetett elektrokémiai cella létrehozását és karakterizálását, melyben a RC munkaelektródra való rögzítését politiofén-ecetsav (PTAA) vezető polimer biztosítja. 
5. A hordozóként használt heteroatommal dópolt és dópolatlan többfalú szén nanocsövek izotóp összetételének meghatározását, továbbá a dópolás szerkezetre gyakorolt hatásának bemutatását.

6. MWCNT/RC kompozit fehérje/hordozó arányának meghatározását gyorsításos tömegspektrometria alkalmazásával.

7. MWCNT/HRP kompozit fehérje/hordozó arányának meghatározását gyorsításos tömegspektrometria alkalmazásával. 


\section{Anyagok és módszerek}

\subsection{Preparatív eljárások}

\subsubsection{Reakciócentrum preparálása}

A méréseimhez használt reakciócentrum fehérjét Rhodobacter (Rb.) sphaeroides R-26 bíborbaktériumból preparáltuk. A baktériumok anaerob környezetben, megvilágítás mellett, fotoheterotróf módon növekedtek. A megvilágítás elött a sejteket 5-8 órán keresztül sötétben tartottuk, hogy a tápoldatban oldott oxigén a sejtlélegzés során felhasználódjon. A RC szolubilizálása a fotoszintetikus membránból N,N-Dimetil-dodecil-amin-N-oxid (LDAO) detergens segítségével történt. A fehérje tisztításához frakcionált ammónium szulfátos kicsapást, majd DEAE Sephacel anioncserélő oszlopkromatográfiát alkalmaztunk. A preparálást követően a $\mathrm{Q}_{\mathrm{B}} \quad$ oldal helyreállítása ubikinon-10 (UQ-10, 2,3-dimetoxi-5-metil-6-dekaizoprenol-pbenzokinon, Sigma) segítségével történt. A fehérje koncentrációját a tároláshoz centrifugával történő ultraszürés segítségével 80-100 $\mu \mathrm{M}$-ra állítottuk be. A fehérjét felhasználásig rutinszerüen $-20{ }^{\circ} \mathrm{C}$-os mélyhütőben tároltuk.

Mind a baktériumtenyésztés, mind a fehérje preparálása a laboratóriumunkban zajlott, melyet Laskayné Tóth Judit laboráns végzett.

\subsubsection{ITO/RC kompozit előállítása}

Az indium ón oxiddal (ITO) bevont üveglapot (specifikus ellenállás $20 \pm 6 \Omega / \mathrm{cm}^{2}$, boroszilikát üveg felületén) kereskedelmi forgalomból szereztük be (Praezisions Glass \& Optik Gmbh, Iserlohn, Németország, Cat No: CEC020B). A gyártás során az ITO felvitele porlasztásos eljárással (sputter-coating) készült. Az ITO/RC kompozitot rászárításos eljárással állítottam elő. 
A minta elökészítése során a detergenst dialízis segítségével távolítottam el a mintából, majd megfelelő hígítást követően $(1 \mathrm{pM}-0,1 \mu \mathrm{M})$ nitrogénáram segítségével szárítottam a felszínre.

\subsubsection{Szén nanocsövek előállítása}

A szén nanocsövek előállítása CCVD (Catalytic Chemical Vapor Deposition - kémiai gázfázisú leválasztás) módszerrel zajlott. A folyamat során katalizátorként $\mathrm{Fe}(\mathrm{III})-$ Co(II)/kálcium-karbonátot vagy nikkel(II)-oxidot alkalmaztunk. A katalizátor $5 \mathrm{~m} / \mathrm{m} \%$ vasat és 5 $\mathrm{m} / \mathrm{m} \%$ kobaltot tartalmazott, melyet impregnációval vittünk fel a hordozó felületére. A számított mennyiségű $\mathrm{Co}(\mathrm{II})$-acetilacetát, $\mathrm{Fe}(\mathrm{III})$-acetilacetát és $\mathrm{CaCO}_{3}$ összemérése és feloldása után az elegyet ultrahang segítségével homogenizáltuk az aggregációk elkerülése érdekében. Az oldat pH-ját ammónia hozzáadásával állítottuk be 9,0-ra. A diszperziót $70{ }^{\circ} \mathrm{C}$-on intenzív mágneses kevertetés mellett hevítettük addig, amíg az oldószer elpárolgott. Az oldószer elpárologtatását követően a katalizátort további 24 órán keresztül $100{ }^{\circ} \mathrm{C}$-on szárítottuk. Nikkel(II)-oxid esetén a NiO-ot acetonban szuszpendáltuk, majd ezt követően cseppentettük fel a szilícium hordozóra.

CCVD eljárás segítségével heteroatommal dópolt szén nanocső is előállítható. A szintézis során nitrogén- és hidrogéngáz elegye áramlik át a reaktoron annak érdekében, hogy megfelelő inert környezetet biztosítsunk a magas hőmérsékleten bekövetkező oxidáció elkerülése érdekében. Az általunk alkalmazott körülmények között a nitrogéngáz nem vesz részt a MWCNT dópolásában, ezért a szintézis során acetiléngáz, tiofén és tripropil-amin (TPA) szolgál szén, kén és nitrogénforrásként. Az acetilén- és a nitrogéngáz egy Y szelep segítségével kerül összekeverésre, míg a folyadékfázisú TPA és a tiofén buborékoltatás segítségével kerül a reaktorba. Intenzívebb TPA bejuttatás egy syringe pumpa segítségével oldható meg (5. ábra) [Szekeres és mtsai., 2015]. 


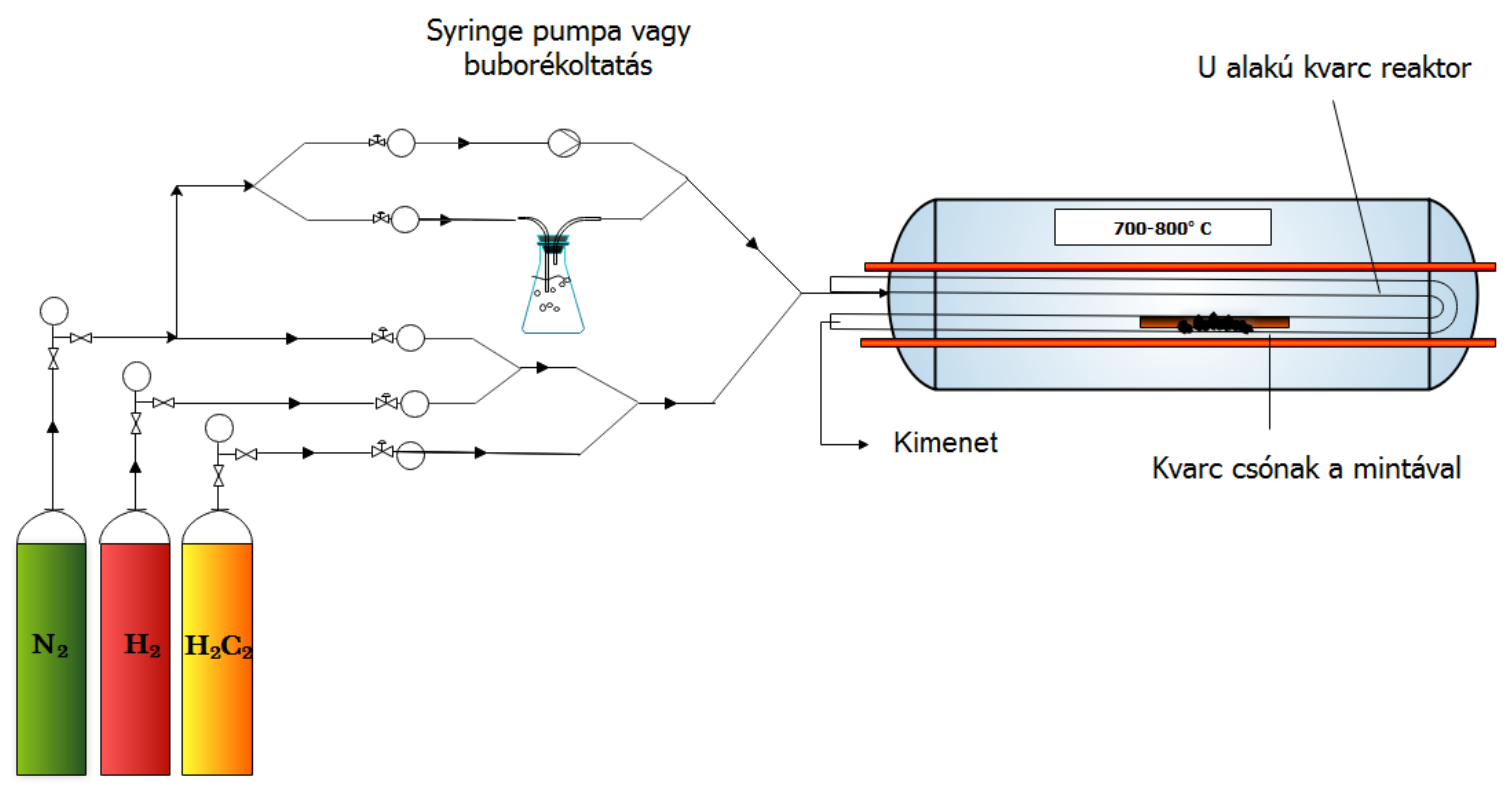

5. ábra

A szén nanocsövek előállításához használt reaktor sematikus ábrája (magyarázat a szövegben)

\subsection{4. $R C$ rögzítése szén nanocső felületén}

Az RC fehérjét karboxilcsoporttal funkcionált szén nanocső felületére rögzítettem. A folyamat során EDC (1-etil-3-(3-dimetilaminopropil)karbodiimid) és NHS (Nhidroxiszukcinimid) aktiválószereket alkalmaztam. Az EDC aktiválja az MWCNT karboxil funkciós csoportjait, így azok képesek az aminokkal reagálni. Az NHS jelentősége a folyamat köztitermékének stabilizálása, ezáltal a keresztkötés nagyobb valószínüséggel való kialakításának az elősegítése.

A preparálás során a karboxilcsoporttal funkcionált szén nanocsövet $(500 \mu \mathrm{L}, 0,14$ $\mathrm{mg} / \mathrm{mL}$ ) foszfát pufferben (PBS) dializáltam (0,1 M; pH 7,0;0,006\% LDAO), ezt követően 1 órán keresztül ultrahanggal homogenizáltam (ELMA Transsonic 310; $35 \mathrm{kHz} ; 70 \mathrm{~W}$; folyamatos üzemmód). A szén nanocsöveket az EDC és NHS oldattal (100 $\mu \mathrm{L}, 0,125 \mathrm{M})$ két órán keresztül kevertettem, ezt követően dializálással távolítottam el a felesleges aktiválószert (PBS 0,1 M; pH 
7,0;0,006\% LDAO). A reakciócentrumot hozzáadva $(50 \mu \mathrm{L}, \mathrm{c} \approx 65 \mu \mathrm{M})$ egy éjszakán át kevertettem a mintát. A nem kötődött reakciócentrumot ultracentrifugálással távolítottam el a keletkezett komplextől $\left(4{ }^{\circ} \mathrm{C}, 15\right.$ perc, $\left.135000 \times \mathrm{g}\right)$. A kialakított komplex felépítésének sematikus rajza a 6 . ábrán látható.

A módszer nem csak oldatfázisban, hanem hasonló módon, felületen is elvégezhető. Ebben az esetben a dializációs lépések egyszerü pufferrel, majd desztillált vízzel történő mosásra egyszerüsödnek. A protokoll optimalizálását Dr. Magyar Melinda végezte [Magyar 2015].

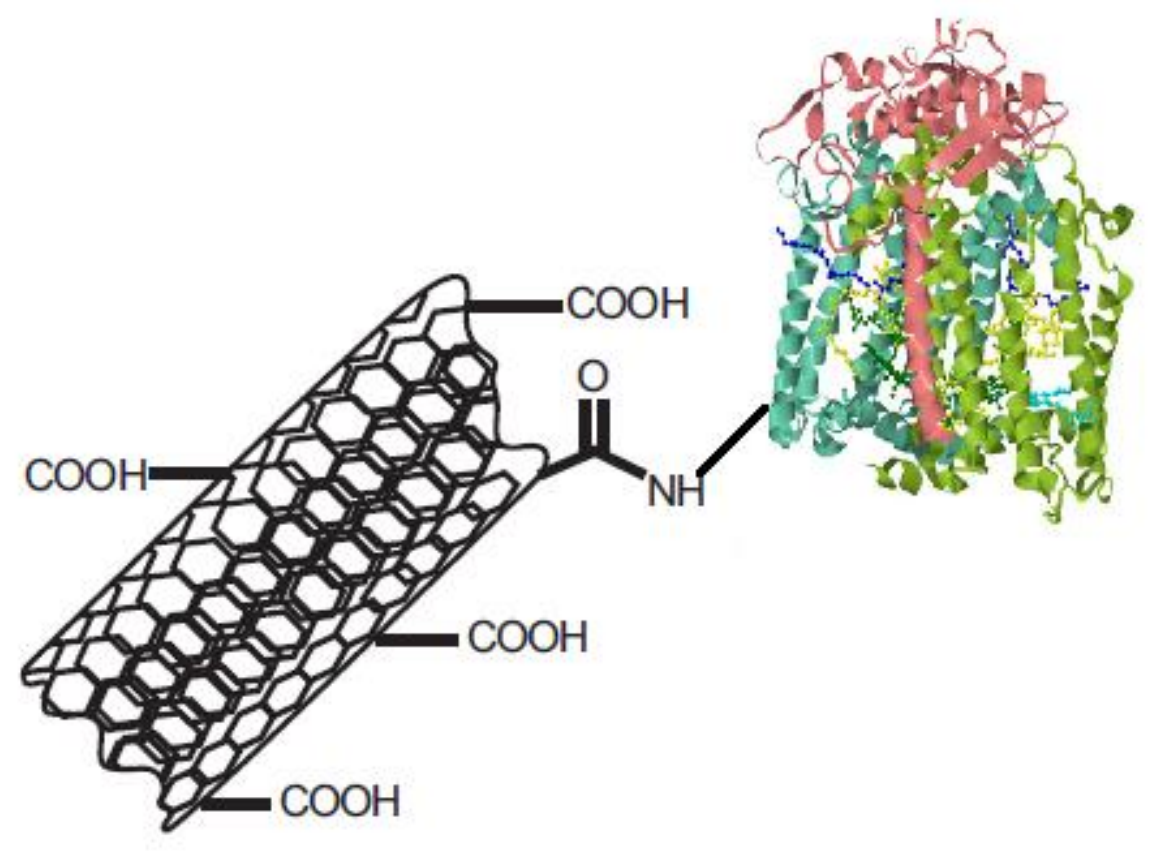

6. ábra MWCNT/RC komplex felépítésének sematikus ábrája (a méretarány nem tükrözi a valóságot) 


\subsubsection{RC rögzítése vezető polimeren keresztül}

Vezető polimeren keresztüli kötéshez PTAA (poli(3-tiofén ecetsav)) vezető polimert használtam, mint kötőszert és mint az elektronok vezetését segítő vezető anyagot egyaránt. Mivel ebben az esetben a PTAA rendelkezik a kötés kialakításához szükséges karboxilcsoporttal, a szén nanocsövek amincsoporttal való funkcionalizálása szükséges. A kötés kialakításához $1 \mathrm{mg} / \mathrm{mL}$ PTAA (0,1 M PBS, pH 8,0) és $0,14 \mathrm{mg} / \mathrm{mL}$ amincsoporttal funkcionalizált MWCNT oldatot összekevertem, majd 2 órán keresztül kevertettem szobahőmérsékleten. A kialakult komplexet a feleslegben lévő polimertől ultracentrifugálással távolítottam el (20 perc, 130000 g), melyet PBSben szuszpendáltam vissza. Ehhez a szuszpenzióhoz adtam hozzá az RC-ot $(65 \mu \mathrm{M}$ törzsoldatból), majd a mintát újra kevertettem két órán keresztül a $\mathrm{RC}$ degradálódásának minimalizálása érdekében, $4{ }^{\circ} \mathrm{C}$-on. Végül a MWCNT/PTAA/RC komplex elválasztása a nem kötött RC-tól szintén ultracentrifugálással történt (20 perc, 130000 g). A kialakított komplex felépítésének sematikus rajza a 7. ábrán látható. 


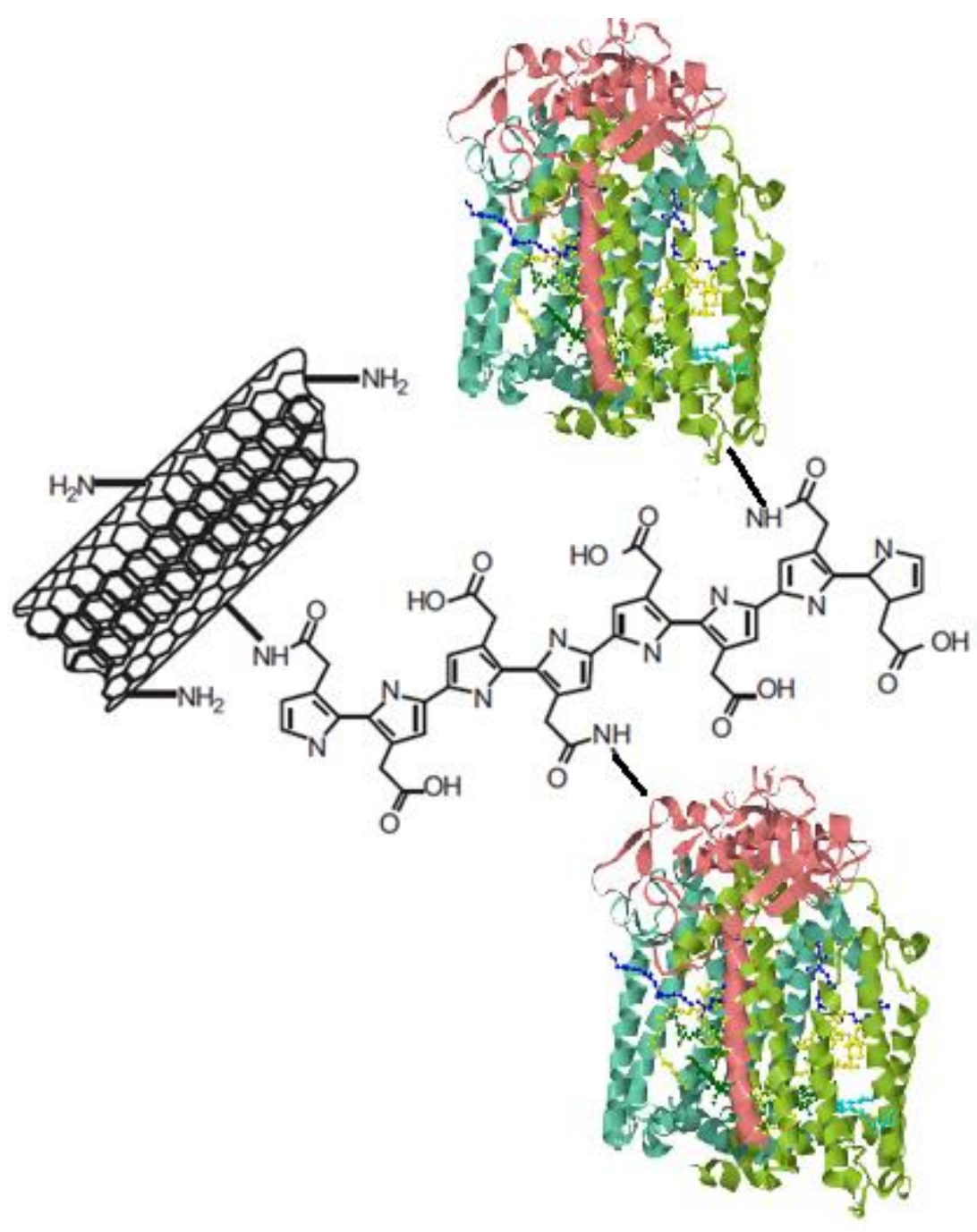

7. ábra

Az MWCNT/PTAA/RC komplex sematikus ábrája (a méretarány nem tükrözi a valóságot)

\subsection{6. $R C$ vezető polimer rétegstruktúrában}

A fehérje és a szervetlen hordozó közötti elektromos kapcsolat jellegének jobb megértése érdekében egy kételektródos rendszert dolgoztam ki. A méréseket jelen esetben is leszárított mintákon végeztem. Elektródként ITO-t és ezüstöt alkalmaztam, melyek közé két vezető polimer réteget vittem fel. Az egyik réteget PEDOT:PSS (poli(3,4-etiléndietoxitiofén):polisztirén- 
szulfonát), a másikat P3HT (poli-3-hexiltiofén) alkotta. A RC kompozit érzékenyítőként került a rendszerbe. A PEDOT:PSS réteget elektrokémiai polimerizációval vittem fel az ITO felületére. A leválasztás vizes közegben zajlott (EDOT 9,8 mM; PSS $165 \mu \mathrm{M}$ ). A ciklikus voltammetria mérések során a kezdő és végpotenciál (-0,5 V és $1,1 \mathrm{~V})$ között $50 \mathrm{mV} /$ perc pásztázási sebességet alkalmaztam (8. ábra). A rétegvastagságot a ciklusok számával állítottam be (kb. $200 \mathrm{~nm}$ ). A P3HT-ből szálas struktúrát alakítottam ki az MWCNT felületén. Ehhez a már előzetesen kémiailag polimerizált P3HT-t kloroform/anizol 9:1 arányú elegyében oldottam fel, majd ehhez az oldathoz adtam hozzá az MWCNT-t. A szén nanocsövek diszpergálása $70{ }^{\circ} \mathrm{C}$-os ultrahangfürdőben történt 30 percen keresztül folyamatos ultrahangozással ( $35 \mathrm{kHz}, 70 \mathrm{~W})$, majd az ultrahangozott szuszpenziót jeges fürdőben hütöttem le. Ezen gyors lehülési folyamat során alakult ki a megfelelő szálas szerkezet [Liu és mtsai., 2009]. Ezt követően porlasztásos eljárással vittem fel a már kialakított PEDOT:PSS rétegre, melyre záró rétegként egy ezüst katód került. Az így előállított rétegstruktúra vázlata a 9. ábrán látható.

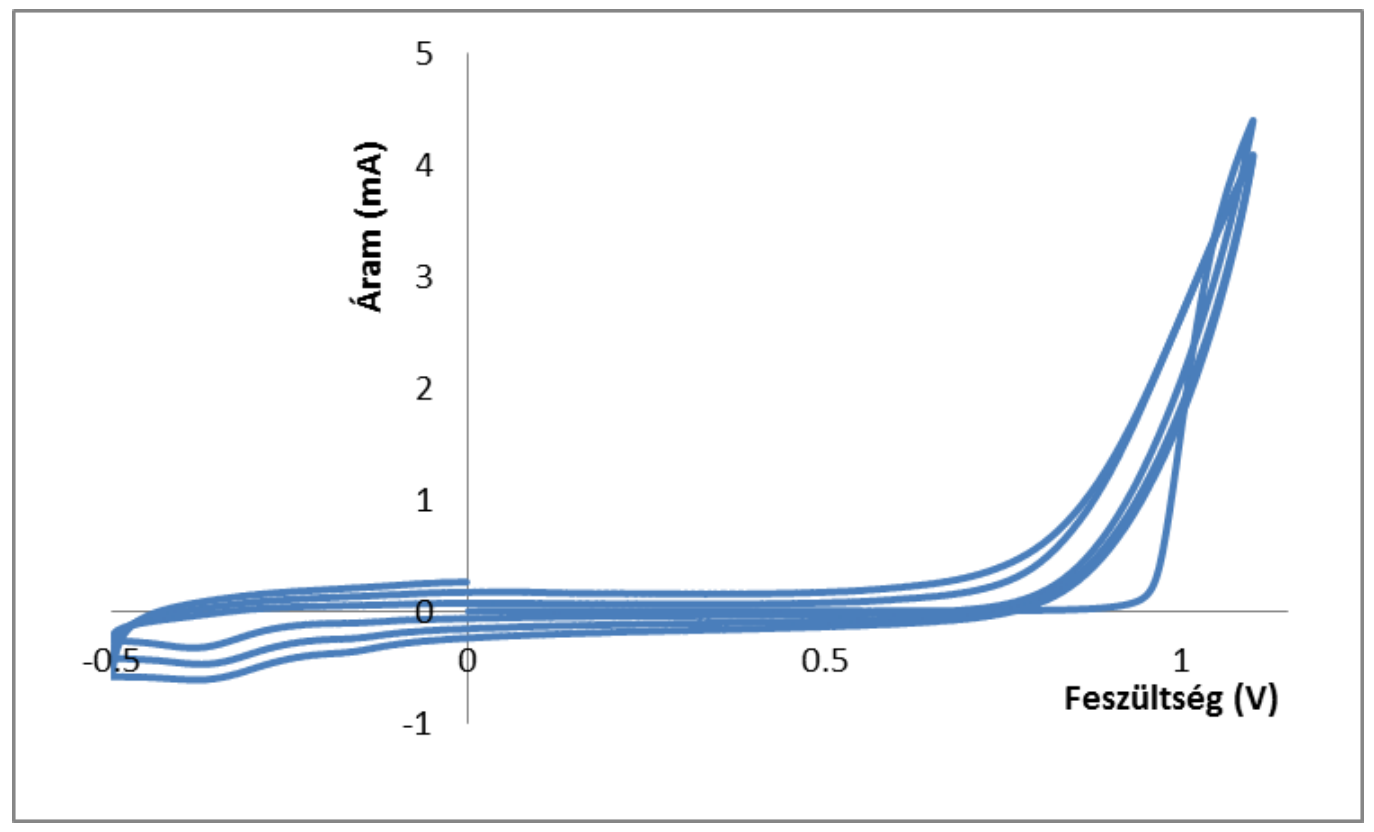

8. ábra

A PEDOT réteg leválasztása ciklikus voltammetria segítségével. A rétegépítés három ciklussal történt. Az ábrán a folyamat feszültség áram karakterisztikája látható. 


\section{Ezüst}

\section{P3HT-MWNT-RC komplex}

\section{PEDOT:PSS}

ITO

\section{Üveg}

\section{9. ábra}

A RC-mal érzékenyített réteges optoelektronikai eszköz sematikus rajza. Elektródként ITO-t és ezüstöt használtam, melyek közé vezető polimer (PEDOT:PSS és P3HT) rétegeket vittem fel. A RC-ot a P3HT rétegbe építettem be.

\subsubsection{Példa egyéb fehérje alkalmazására: Tormaperoxidáz enzim}

A bemutatott preparatív és az általam használt karakterizálási eljárások egyéb fehérjékre is alkalmazhatóak. Jelen esetben ezt egy tormaperoxidáz enzim (HRP) példáján mutatom be, melyet EDC/NHS módszerrel rögzítettem MWCNT felületére, az alábbi protokoll szerint.

A preparálás során a karboxilcsoporttal funkcionált szén nanocsövet $(500 \mu \mathrm{L}, 0,14$ $\mathrm{mg} / \mathrm{mL}$ ) foszfát pufferben dializáltam ( $0,1 \mathrm{M} ; \mathrm{pH}$ 7,0;0,006\% LDAO), melyet ezt követöen 1 órán keresztül ultrahanggal homogenizáltam (ELMA Transsonic 310; $35 \mathrm{kHz} ; 70 \mathrm{~W}$; folyamatos üzemmód). A szén nanocsöveket az EDC és NHS oldattal (100 $\mu \mathrm{L} ; 0,125$ M) két órán keresztül kevertettem, ezt követően dializálással távolítottam el a felesleges aktiválószert (PBS 0,1 M; pH 7,0; 0,006\% LDAO). A HRP enzimet hozzáadva (1 mg/mL, Sigma Aldrich) egy éjszakán át 
kevertettem. A nem kötődött tormaperoxidáz enzimet ultracentrifugálással távolítottam el a keletkezett komplextől $\left(4^{\circ} \mathrm{C}, 15\right.$ perc, $\left.135000 \times \mathrm{g}\right)$.

\subsection{Vizsgálati módszerek}

\subsubsection{Képalkotó eljárások}

\subsubsection{Atomi erő mikroszkópia AFM}

Az elkészített kompozitok szerkezetének vizsgálatára különböző képalkotási módszereket alkalmaztam, melyek közül egyik az atomi erő mikroszkópia volt. A felvételekhez egy Molecular Force Probe 3D (Asylum Research, Santa Barbara, CA, USA) AFM készüléket használtam, amely egy Asylum MFP-3D fej segítségével müködött. A felvételek tapogató módban, Olympus AC160 AFM tủ alkalmazásával, száraz körülmények között készültek. A képek elkészítését Szegletes Zsolt végezte az MTA SZBK-ban, a kiértékeléseket viszont én végeztem.

\subsubsection{Transzmissziós elektronmikroszkópia}

A minták szerkezetét transzmissziós elektronmikroszkópiával (TEM) is vizsgáltam. A mérésekhez egy FEI Technai G2 20 X-TWIN típusú készüléket használtam. A TEM vizsgálatok információval szolgálnak az MWCNT szerkezetéről is, így a dópolás szerkezetre gyakorolt hatása is tanulmányozható. A méréshez a mintát abszolút etanolban diszpergáltam ultrahang segítségével (Transsonic T570/H, $35 \mathrm{kHz}, 320 \mathrm{~W}$ ), ezt követően csöppentettem fel egy szénbevonatos $\mathrm{Cu}$ TEM gridre (200 Mesh). 


\subsubsection{Spektroszkópiai módszerek}

A RC fehérje jellemző abszorpciós spektrummal bír a látható és a közeli infravörös tartományban, így egyensúlyi spektroszkópiai mérésekkel a reakciócentrum jelenléte és koncentrációja is meghatározható. Az egyensúlyi spektroszkópiai mérésekhez egy UNICAM UV4 típusú kétsugaras készüléket használtam. A fényszórás minimalizálásának érdekében közeli mintatartó helyzetet alkalmaztam.

Fénygerjesztést követően a reakciócentrumban lezajló folyamatok szintén követhetőek kinetikai spektroszkópiai módszerekkel, így a folyamatok dinamikája is tanulmányozható. Méréseimhez egy saját építésű kinetikai spektrofotométert használtam, melynek a sematikus rajza a 10. ábrán szerepel. Ezzel a mórszerrel a $\mathrm{P} / \mathrm{P}^{+}$primer elektrondonor bakterioklorofill dimer $(\mathrm{P})$ redoxváltozása $(860 \mathrm{~nm})$, valamint a bakteriofeofitin (Bfeo) elektrokromikus eltolódása (771 nm) is követhetö, mely a $\mathrm{Q}_{\mathrm{A}}{ }^{-} \mathrm{Q}_{\mathrm{B}}$ és $\mathrm{Q}_{\mathrm{A}} \mathrm{Q}_{\mathrm{B}}{ }^{-}$állapotok közötti elektronátmenetet jellemzi.

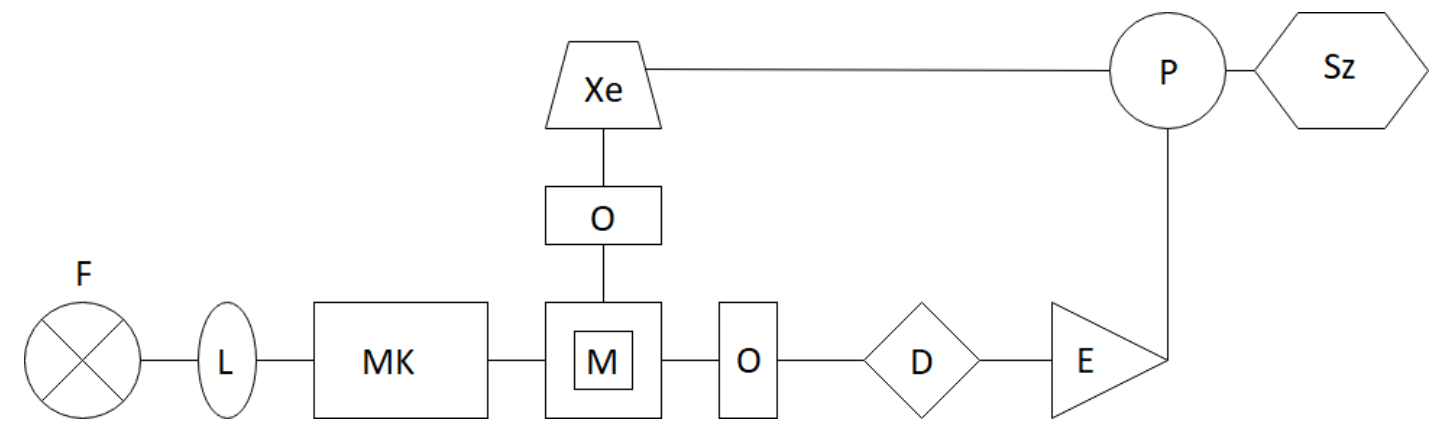

10. ábra

Az egysugaras kinetikai abszorpcióváltozás-mérő komponenseinek elhelyezkedése. Ahol: F-mérőfény, L-lencse, MK-monokromátor, M-mintartó a mintával, O-optikai szürő, D-detektor, E-erősítő, Xe-xenon villanólámpa, P-oszcilloszkóp, Sz-számítógép. 


\subsubsection{Ellenállásmérés}

A minták ellenállás-változásának mérését egy Keithley 2400s típusú multiméterrel 7 digit feloldással végeztem, 4 pontos elrendezésben. A készüléket számítógép segítségével USB porton keresztül vezéreltem, egy erre a célra általam készített LabVIEW program segítségével. A mérés során a fénnyel való gerjesztést egy $250 \mathrm{~W}$ teljesítményű wolframszálas izzólámpa fénye szolgáltatta, melyböl egy $400 \mathrm{~nm}$ levágási frekvenciájú aluláteresztő szürő segítségével választottam ki megfelelő gerjesztő fényt.

\subsubsection{Elektrokémiai eljárások}

A RC aktivitását az eloállított kompozitokban spektroszkópiai mérések mellet elektrokémiai mérésekkel is igazoltam. A mérések háromelektródos elrendezésben történtek. Munkaelektródként ITO-val borított üvegelektródot használtam. Ennek előnye, hogy a látható tartományban igen jó transzmisszióval rendelkezik, így a fénnyel való gerjesztés könnyen megoldható, emellett a vezetési tulajdonságai is megfelelőek maradnak elektródként való alkalmazásra. Az elkészített kompozitokat minden esetben kémiai kötéssel rögzítettem a munkaelektród felszínére kizárva annak a lehetőségét, hogy a kompozit vizes környezetben leoldódjon az elektródfelszínről. A rendszerben ellenelektródként platinát, míg referenciaként $\mathrm{Ag} / \mathrm{AgCl}$ elektródot használtam. Az alkalmazott elektrokémiai cella sematikus rajza a 11 ábrán látható. Az elektrokémiai mérések során a munkaelektród felülete minden esetben $1 \mathrm{~cm}^{2}$ volt. 


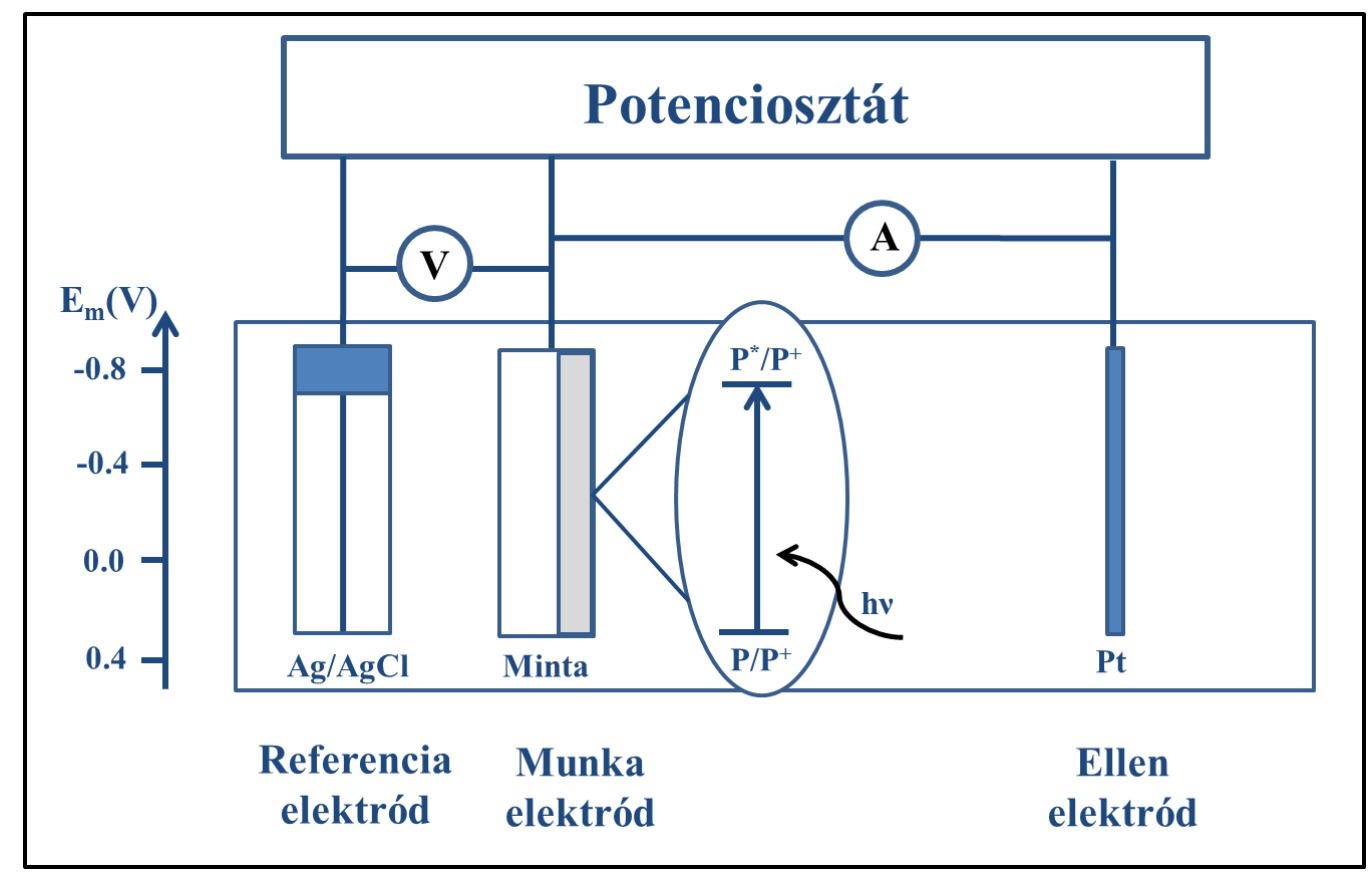

\section{1. ábra}

Az alkalmazott elektrokémiai cella sematikus ábrája (magyarázat a szövegben)

\subsubsection{Izotópanalitikai mérések}

\subsubsection{Szénizotóp-tartalom meghatározása}

C14-izotóp meghatározásához először a minta széntartalmának feltárására volt szükség, amelyet egy zárt csöves égetéses eljárással értünk el. A mintát és az oxidálószerként használt $\mathrm{MnO}_{2}$-ot egy kvarccsőbe mértem. Amennyiben a minta vizet is tartalmazott, azt fagyasztva szárítással távolítottam el. A minta tömegét ebben az esetben a kvarccső és a fagyasztva szárítást követő tömeg különbségeként határoztam meg. A bemérést követően a csőben lévő nyomást $<5 \cdot 10^{-3}$ mbar-ra csökkentettem, majd leforrasztottam. A mintát a leforrasztott csőben, egy kemencében $550{ }^{\circ} \mathrm{C}$-on 48 órán keresztül égettem el. A keletkezett $\mathrm{CO}_{2}$-ot az esetlegesen képződött egyéb gázoktól egy kriotechnikai csapda segítségével választottam el. A $\mathrm{CO}_{2}$ mennyiségét jól definiált térfogaton egy precíziós nyomásszenzor segítségével határoztam meg 
[Janovics 2016]. A szén kitermelésének hatásfoka a keletkezett $\mathrm{CO}_{2}$ mennyiségének segítségével számítható. A kinyert tisztított $\mathrm{CO}_{2}$ grafittá alakítása cink felhasználásával szintén zárt csöves eljárássál zajlott [Rinyu és mtsai., 2013, Orsovszki és Rinyu 2015]. Kevesebb, mint 100 g szén esetén mikrografitizációs eljárás szükséges [Rinyu és mtsai., 2015].

A szénizotóptartalom meghatározásához egy MICADAS típusú tömegspektrométert alkalmaztunk [Synal és mtsai., 2004, 2007 Molnár és mtsai., 2013], melynek sematikus rajza a 12. ábrán látható. A méréseket az MTA Atommagkutató Intézetében, Debrecenben végeztem. Az elökezelés és égetés során a legnagyobb körültekintés mellett is lehetőség van arra, hogy a mintába radioaktív szén izotóp kerüljön a jelenkori légkörben előforduló szénforrásból. Ennek követése érdekében jól definiált szénizotóp tartalmú standardokon (IAEA C7 and C8, [Le Clercq és mtsai., 1998]) is végrehajtottuk a kezeléseket és a mérés során ezeket referenciaként alkalmaztuk. A kiértékelés során a BATS AMS szoftvert használtuk [Wacker és mtsai., 2010].

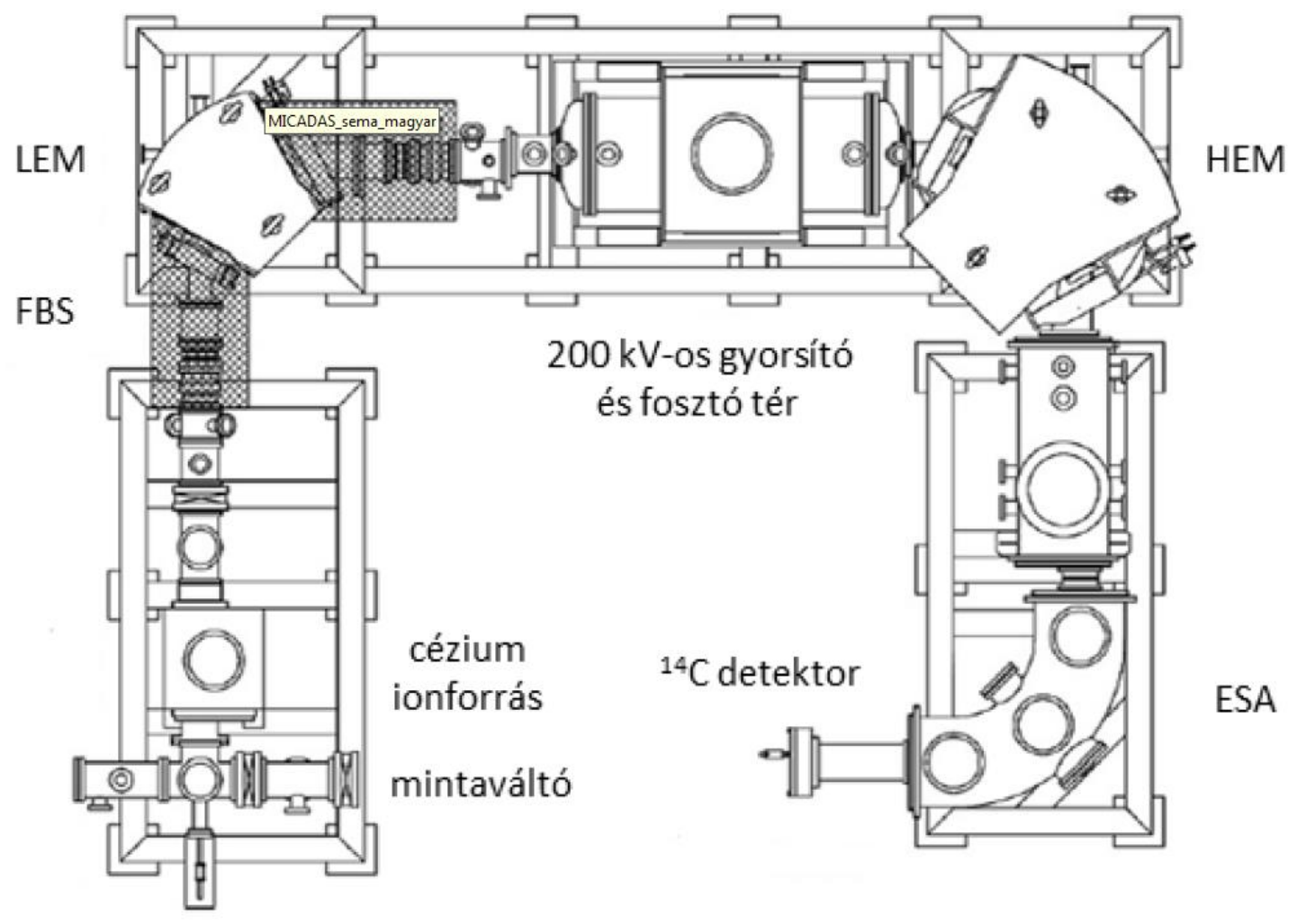

12. ábra

A szénizotóp mérésekhez használt MICADAS AMS típusú tömegspektrofotométer sematikus rajza [Synal és mtsai., 2007] 


\subsubsection{Stabilizotóp-mérések}

A stabilizotóp meghatározásokhoz egy Thermo Finnigan Delta ${ }^{\mathrm{Plus}} \mathrm{XP}$ típusú izotóparányt mérő spektrofotométert alkalmaztam, mely egy Fisons NA1500 NCS elemanalizátorhoz csatlakozott. Ez az eljárás a minta gyors elégetésén alapul, mely során mind a szerves, mind a szervetlen komponensek égéstermékekké alakulnak. A keletkezett gázok elválasztása egy kromatográfiás oszlop segítségével történik, a detektálást egy tömegspektrométer végzi [Major és mtsai. 2017]. Az eredményeket az alábbi formalizmussal adjuk meg $\delta(\%)=\left(\mathrm{R}_{\text {minta }} / \mathrm{R}_{\text {referencia }}-1\right)$ * 1000, ahol $\mathrm{R}{ }^{13} \mathrm{C} /{ }^{12} \mathrm{C}$, vagy a ${ }^{15} \mathrm{~N} /{ }^{14} \mathrm{~N}$ arányt jelöli a minta és a referenciaként alkalmazott standard esetén. A mérés bizonytalansága $0,2 \% \delta^{13} \mathrm{C}$ és $\pm 0,3 \%{ }_{0} \delta^{15} \mathrm{~N}$ esetén.

\subsubsection{Kéntartalom-mérése}

A kéntartalom méréséhez a szén nanocső minták feltárása egy Mars 5 típusú mikrohullámú feltáró segítségével történt. A feltárás során a minta 50 mg-ját $2 \mathrm{~mL}$ 67\%-os salétromsavval egy teflonbombába helyezzük, melyet mikrohullám alkalmazásával (800 W) 200 ${ }^{\circ} \mathrm{C}$-ra hevítünk. A folyamat 20 percet vesz igénybe, majd további 30 percig tartjuk a megadott hőmérsékleten a rendszert. Ezt követően a mintát ultratiszta víz segítségével 50 mL-re hígítjuk.

A kéntartalom meghatározását egy Agilent 8800 ICP-QQQ-MS tömegspektrométerrel elemeztük MS/MS módban. A kéntartalom meghatározása 48 tömeg/töltés hányadosú elem tömegeltolódás mérésén alapszik, az alábbi egyenlet szerint:

$$
{ }^{32} \mathrm{~S}^{+}+{ }^{32} \mathrm{O}_{2}={ }^{32} \mathrm{~S}^{16} \mathrm{O}^{+}+{ }^{16} \mathrm{O}
$$




\section{Eredmények és értékelésük}

\subsection{ITO és ITO/RC kompozit szerkezetének tanulmányozása}

AZ ITO/RC kompozit szerkezetének vizsgálatát atomerő mikroszkópiás módszer segítségével végeztem. A 13. A és B ábra mutatja a kompozitról készült amplitúdó és fázis képet. Az ábrák bal oldalán reakciócentrum borítottság figyelhető meg, melyet a magasságkép is igazol. Ezen a területen a minta felületi érdessége nagyobb (körülbelül $10 \mathrm{~nm}$ ), mint az ITO hordozó mikrokristályos szerkezetéből adódó felületi érdesség (3,5-5 nm), amely jó egyezést mutat az RC fehérje méretével. A D ábrán referenciaként egy mica felületén lévő individuális reakciócentrum látható [Nagy és mtsai., 2010]. 

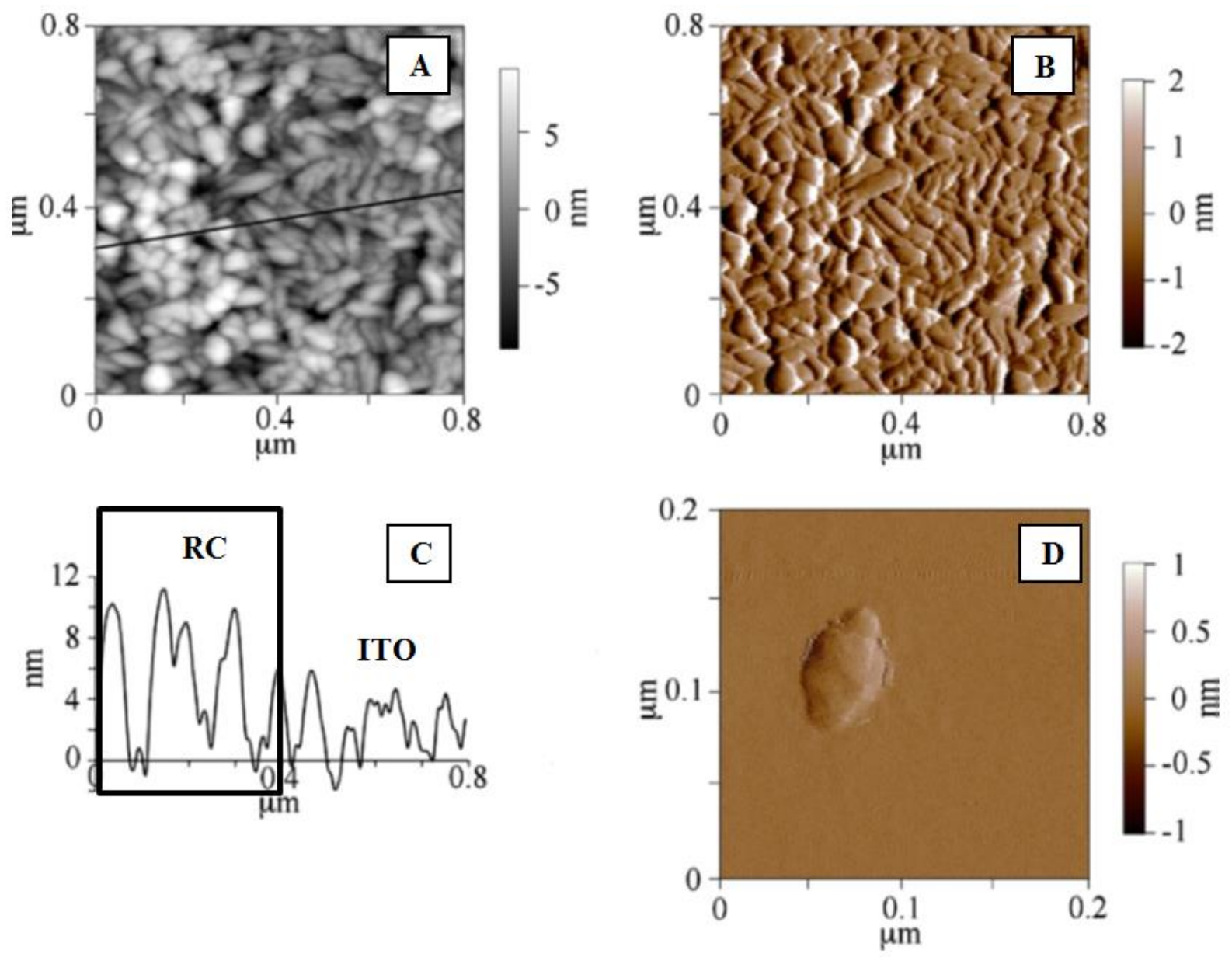

\section{3. ábra}

Üvegfelületre felvitt reakciócentrummal érzékenyített ITO hordozóról AFM-mel készített amplitúdó (A) és fáziskép (B). A borítottság részleges, a RC-ot tartalmazó régió a magasságképen (C) jelölve van. A mérés AC módban száraz körülmények között zajlott, a kísérleti részben leírtak szerint. A (D) jelü ábra egy mica felületen lévő egyetlen reakciócentrumról készült. 


\subsection{Szén nanocső hordozó karakterizálása}

A szén nanocső hordozó struktúráját, valamint a dópolás szerkezetre gyakorolt hatását TEM mérések segítségével vizsgáltam. Mind a nitrogén, mind a kén heteroatom beépítése a szerkezetbe jelentős változásokat okoz, ami a 14-16. ábrákon jól látható. A 15. ábra a nitrogénnel dópolt MWCNT szerkezetét mutatja. Összehasonlítva a 14. referencia ábrával, megfigyelhető az úgynevezett bambusz szerkezet kialakulása, melyet a cső struktúra megszünése, belső zárt üregek kialakulása jellemez. A kén beépülése is hasonló látványos szerkezeti változást eredményez, ezen esetben a lineáris csőszerkezet spirálisra módosul (16. ábra). Ezen két példa is jól szemlélteti, hogy megegyező reakciókörülmények között a dópoló atom hatására különböző struktúrák képesek kialakulni [Szekeres és mtsai., 2015, Yang és mtsai., 2015].

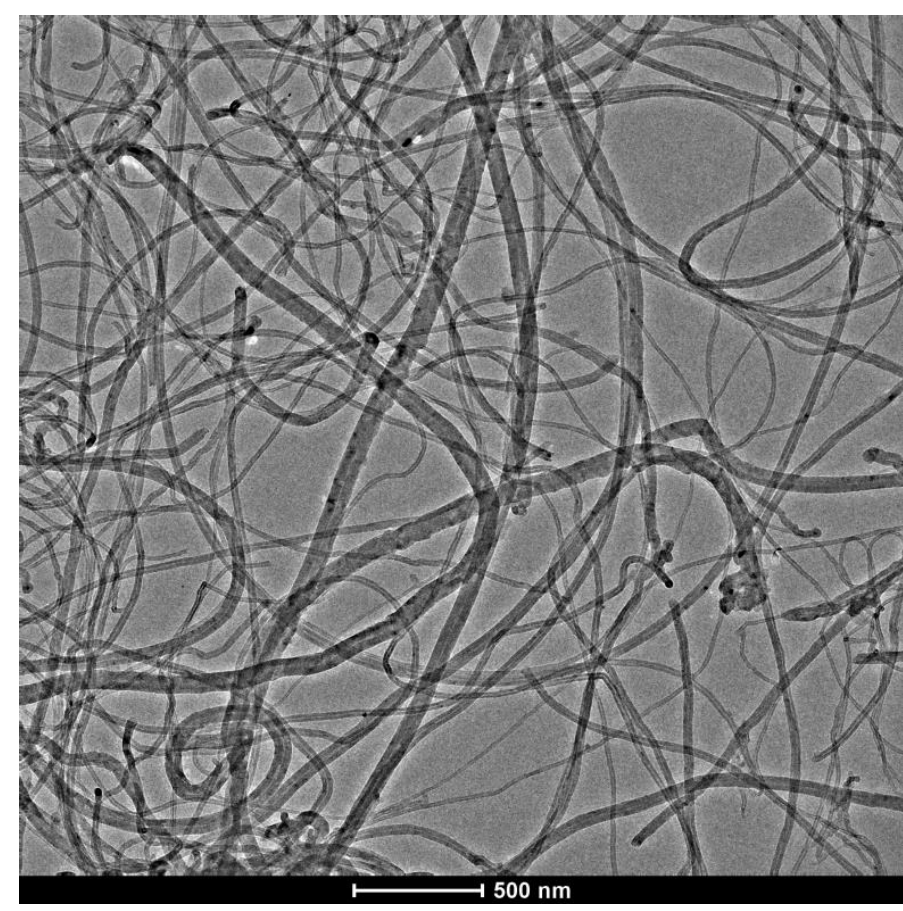

14. ábra

Dópolásmentes MWCNT mintáról készült TEM felvétel 


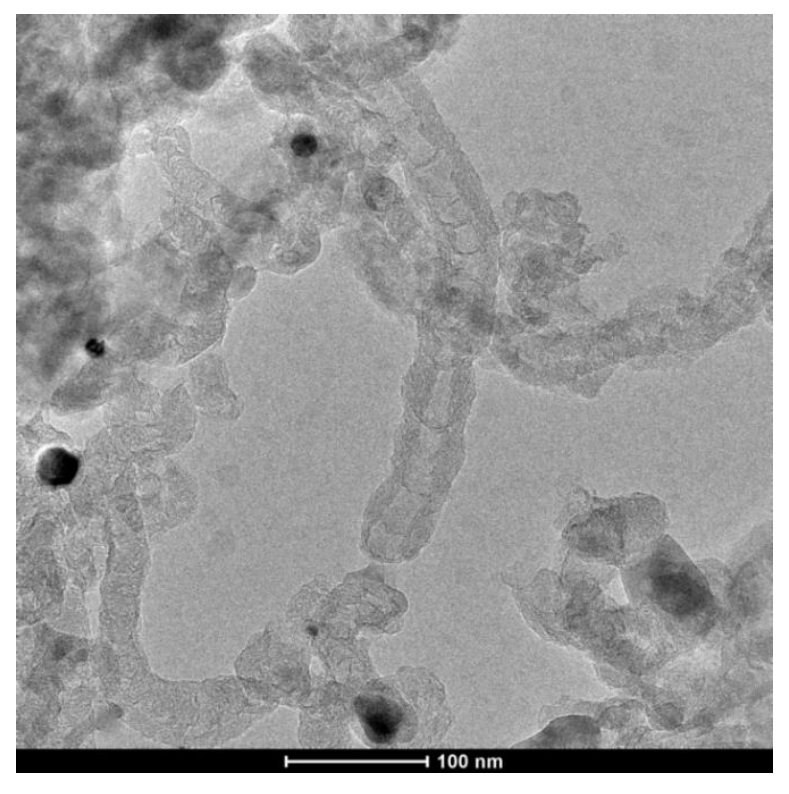

15. ábra

Nitrogénnel dópolt MWCNT mintáról készült TEM felvétel. A felvételen jól megfigyelhető a heteroatom beépülése által okozott strukturális változás, mely úgynevezett „,bambusz struktúrát” eredményez.

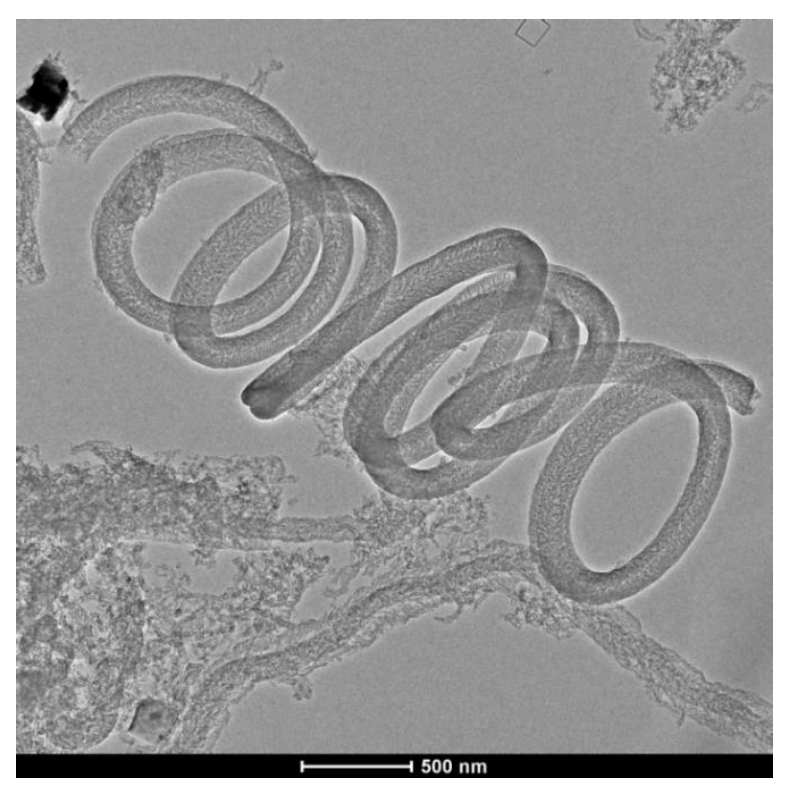

16. ábra

Nitrogénnel dópolt MWCNT mintáról készült TEM felvétel. A felvételen jól megfigyelhető a heteroatom beépülése által okozott strukturális változás, mely spirális struktúrát eredményez. 


\subsection{Spektroszkópiai jellemzések}

\subsubsection{Egyensúlyi abszorpciós spektroszkópia}

A RC és az ITO jellemzéséhez egyensúlyi abszorpciós méréseket hajtottam végre. A 17. ábrán látható, hogy a RC jellemző elnyeléssel rendelkezik a vörös és a kék tartományban. A vörös régióban három jellemző abszorpciós sáv van 760, 802 és 860 nm-es abszorpciós maximummal. A $760 \mathrm{~nm}$ a bakteriofeofitinhez, a $802 \mathrm{~nm}$ a bakterioklorofill monomerhez, a 860 mn pedig a bakterioklorofill dimerhez rendelhetö. A bakterioklorofill a kék tartományban is rendelkezik jellemző elnyelési sávval, melyet Soret sávnak nevezünk (300-420 nm). A fehérjeváz aromás aminosavai $280 \mathrm{~nm}$ es maximummal jellemzett tartomány körül abszorbeálnak.

Az ITO hordozó látható tartományban mért abszorpciója igen alacsony, így a látható fény jelentős részét átengedi, mely a rá helyezett kompozit fénnyel való gerjesztését megkönnyíti, mivel az üveg felől is lehetségessé válik a minta megvilágítása. Az UV tartományban mind az ITO, mind az üveg elnyel. Az ITO UV-beli elnyelési maximumának meghatározása érdekében tömény kénsav és 30\% hidrogén-peroxid 3:1 arányú elegyével eltávolítottam az ITO bevonatot az üveg felületéről, majd az ITO-ra jellemző spektrumot az ITO/üveg és az üveg referencia különbségeként határoztam meg. 


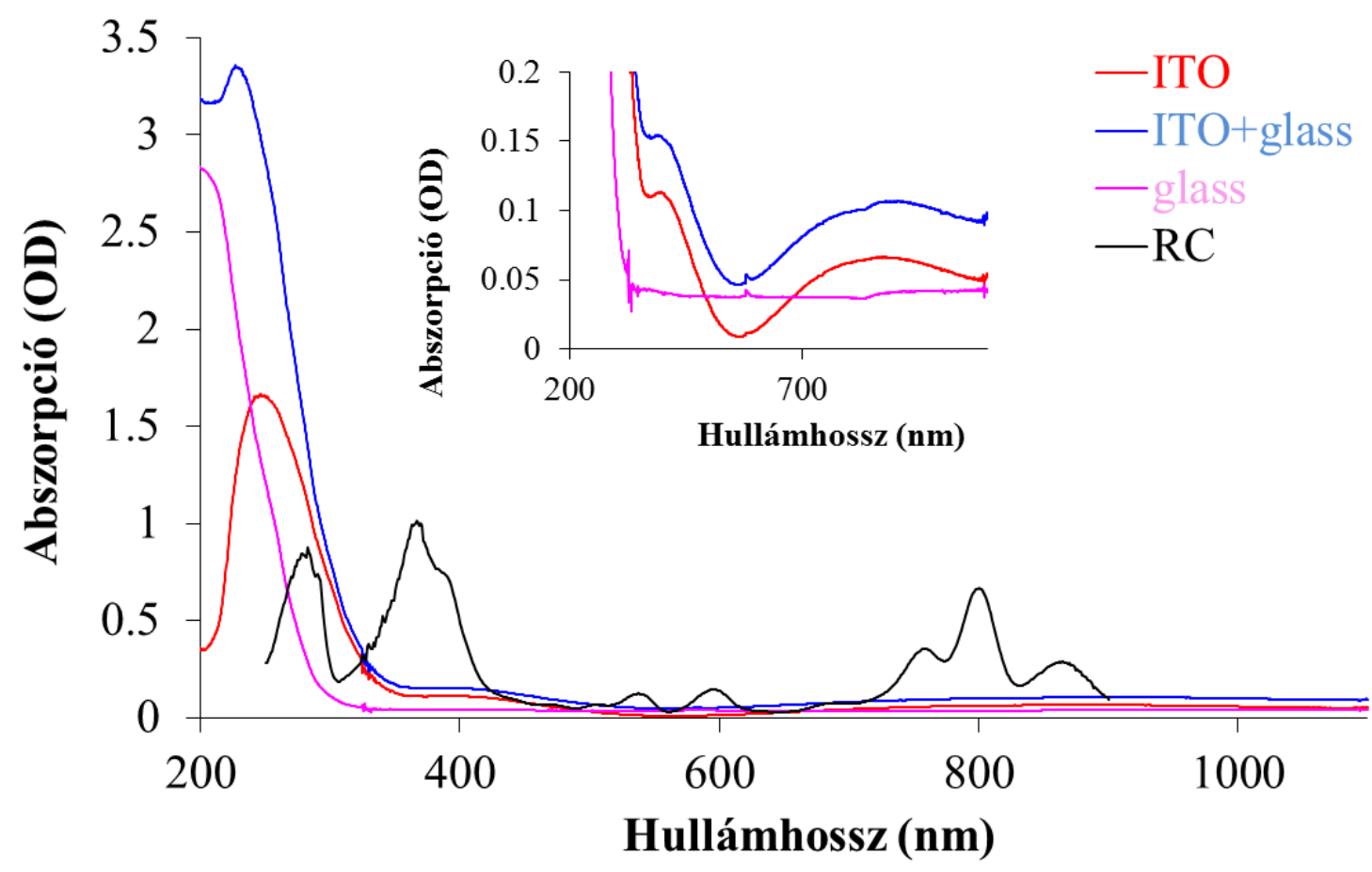

17. ábra

ITO, ITO és üveghordozó, üveghordozó és oldatbeli RC egyensúlyi abszorpciós spektruma. Az üveg referenciát az ITO réteg tömény kénsav és 30\% hidrogén-peroxid 3:1 arányú elegyével történő eltávolítását követően mértem meg. Az ITO spektruma az így megmért üveghordozó és az eredeti ITO minta különbségi spektrumaként adódott. A beillesztett ábrán a látható tartomány kinagyítása látható.

\subsubsection{Abszorpció kinetikai mérések}

A 18. ábra az RC 771 nm-en mért fénnyel való gerjesztését követő abszorpció kinetikai változását mutatja különböző mérési körülmények között. A bakteriofeofitin $771 \mathrm{~nm}$-en mért abszorpcióváltozása a fehérjén belüli elektrontranszportról szolgáltat információt. A mérés időben 6 nagyságrendet ölel fel $\left(10^{-5}-10 \mathrm{~s}\right)$, így mind a töltésszétválasztás és stabilizálódás 
folyamata $\left(\mathrm{P}^{+} \mathrm{Q}_{\mathrm{A}}{ }^{-} \mathrm{Q}_{\mathrm{B}} \rightarrow \mathrm{P}^{+} \mathrm{Q}_{\mathrm{A}} \mathrm{Q}_{\mathrm{B}}{ }^{-}\right)$, mind a töltés rekombinációs folyamatok $\left(\mathrm{P}^{+} \mathrm{Q}_{\mathrm{A}} \mathrm{Q}_{\mathrm{B}}{ }^{-} \rightarrow \mathrm{PQ}_{A} \mathrm{Q}_{B}\right)$ követhetőek. Az adatok illesztése első rendü kinetikai egyenlettel történt:

$$
A(t)=\sum_{i} A_{i} e^{\left(-k_{i} t\right)},
$$

ahol $A(\mathrm{t})$ a jel amplitúdója az idő függvényében, $k_{\mathrm{i}}$ és $A_{\mathrm{i}}$ pedig az i-edik komponens reakciósebességi állandója és amplitúdója. Az illesztési paraméterek a 1. táblázatban kerültek összegzésre.

A 771 nm-en mérhető abszorpciókinetikát jelentősen befolyásolják a környezeti tényezők. Alapvető hatása van például a környezet pH-jának, a hömérsékletnek, a viszkozitásnak, az ionerősségnek [Tiede és mtsai., 1996, 1998, Graige és mtsai., 1998]. Ismeretes továbbá az is, hogy lipid környezetben modellezve az in vivo körülményeket a fényindukált töltésszétválasztás energetikája módosul [Milano és mtsai., 2007, Nagy és mtsai., 2004]. A RC szén nanocsőhöz való rögzítése szintén befolyásolja a töltésszétválasztás kinetikáját [Dorogi és mtsai., 2006, Hajdu és mtsai., 2011, Magyar és mtsai., 2011].

A $860 \mathrm{~nm}$-en mért abszorpcióváltozás a primer donor (bakterioklorofill dimer, $\left.(\mathrm{Bklo})_{2}\right)$ redox-állapotát jellemzi. A 18. ábra (valamint az 1. táblázatban, mely az 18. ábra görbéire illeszett függvények illesztési paramétereit foglaja össze) alapján látható, hogy miközben a gerjesztést követően a primer donor redox-állapotában csak elhanyagolható változás történik (kis változás a $860 \mathrm{~nm}$ mért abszorpció gyors komponensében), addig a bakteriofeofitin elektrokróm eltolódásának amplitúdója és időállandója is jelentős mértékben megváltozik, ha a RC ITO felületre van helyezve. Sajnos a nagy fényszórás miatt nem tudtunk két komponenst feloldani az ITO/RC kompozit $\mathrm{P}^{+} \mathrm{Q}_{A}{ }^{-} \mathrm{Q}_{B} \rightarrow \mathrm{P}^{+} \mathrm{Q}_{A} \mathrm{Q}_{B}{ }^{-}$elektrontranszport gyors fázisában, mint oldatfázis esetén, de így is látható, hogy az előremenő elektrontranszfer időállandója megnövekedett az üvegfelületen tapasztalthoz képest $\left(k_{\mathrm{AB}}\right.$,lassú=448 $\mathrm{s}^{-1}$ és $\left.1711 \mathrm{~s}^{-1}\right)$. A $771 \mathrm{~nm}$-en mért abszorpciókinetika felgyorsulása és a 860 nm-en mért redoxváltozásban történt kismértékü változás arra enged következtetni, hogy redoxcsatolás feltételezhető a fehérje és az ITO hordozó között. 


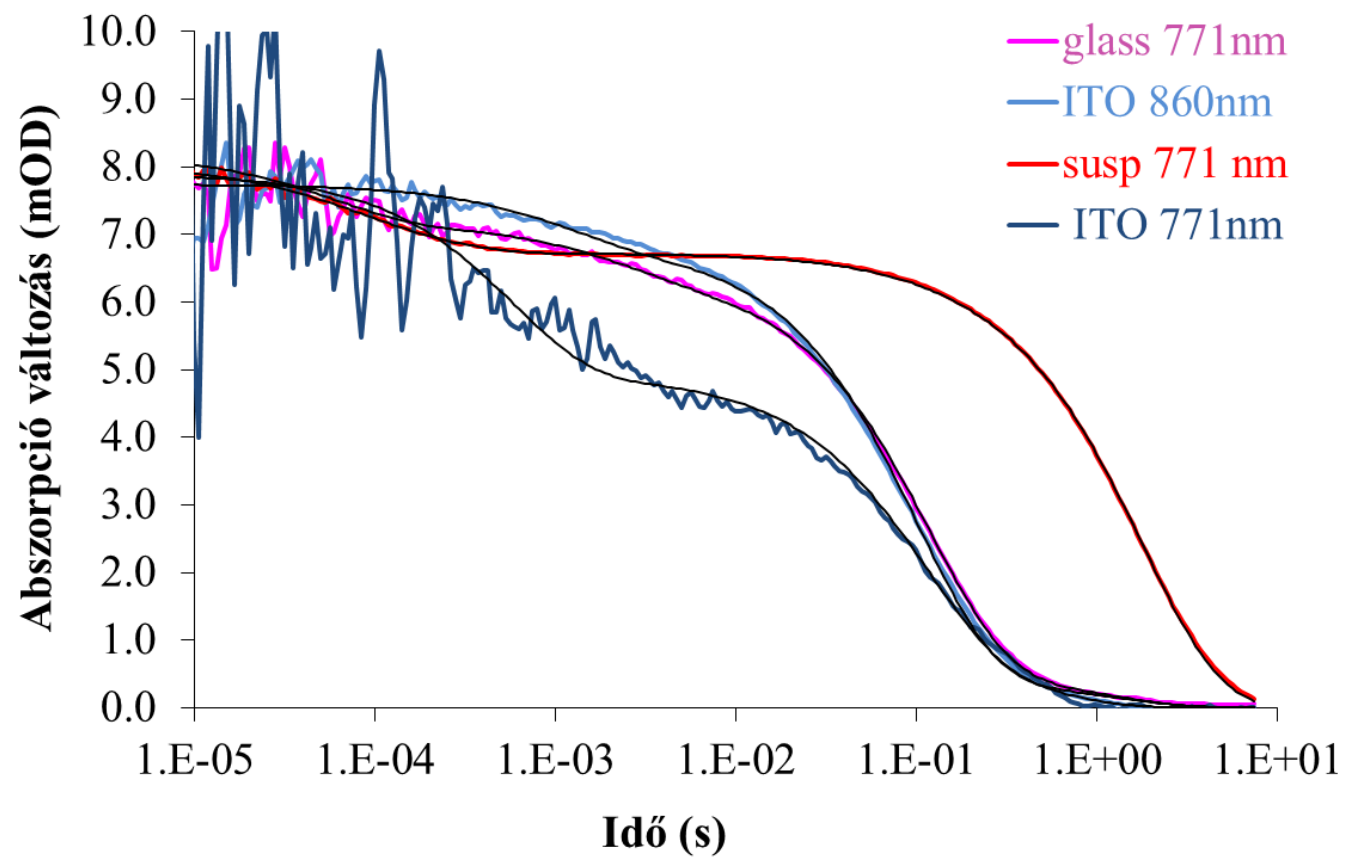

18. ábra

$R b$. sphaeroides R26 baktériumból izolált RC telítési fényimpulzust követő abszorpció kinetikája.

A mérést $771 \mathrm{~nm}$ hullámhosszon boroszilikát üveg és ITO felületen száraz körülmények között végeztem. Összehasonlításképpen a $860 \mathrm{~nm}$ hullámhosszon ITO felületen végzett mérés és a 771 nm hullámhosszon szuszpenzióban mért RC abszorpciókinetikája is feltüntetésre került. A folytonos vonallal az illesztett görbéket jelöltem, az illesztési paramétereket a 1. táblázatban tüntettem fel.

\begin{tabular}{|c|c|c|c|c|c|c|c|c|c|}
\hline & \multirow{2}{*}{$\begin{array}{c}\left(\mathrm{Q}_{\mathrm{A}}{ }^{-} \mathrm{Q}_{\mathrm{B}} \rightarrow\right. \\
\mathrm{A}_{\mathrm{AB}, \text { gyors }} \\
(\%) \\
\end{array}$} & \multirow{2}{*}{ 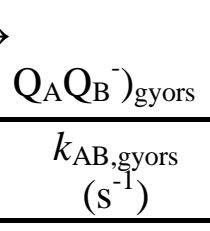 } & \multicolumn{2}{|c|}{$\begin{array}{l}\left(\mathrm{Q}_{\mathrm{A}}{ }^{-} \mathrm{Q}_{\mathrm{B}} \rightarrow\right. \\
\left.\quad \mathrm{Q}_{\mathrm{A}} \mathrm{Q}_{\mathrm{B}}{ }^{-}\right)_{\text {lassú }}\end{array}$} & \multicolumn{3}{|c|}{$\mathrm{P}^{+} \mathrm{Q}_{\mathrm{A}}^{-} \rightarrow \mathrm{PQ}_{\mathrm{A}}$} & \multicolumn{2}{|c|}{$\mathrm{P}^{+} \mathrm{Q}_{\mathrm{B}}^{-} \rightarrow \mathrm{PQ}_{\mathrm{B}}$} \\
\hline & & & $\begin{array}{c}\mathrm{A}_{\mathrm{AB}, \text { lassú }} \\
(\%)\end{array}$ & $\begin{array}{c}k_{\mathrm{AB} \text {,lassú }} \\
\left(\mathrm{s}^{-1}\right)\end{array}$ & $\begin{array}{r}\mathrm{A}_{\text {gyors }}+ \\
\mathrm{A}_{\text {lassú }} \\
\end{array}$ & $\begin{array}{l}\mathrm{A}_{\mathrm{AP}} \\
(\%) \\
\end{array}$ & $\begin{array}{l}k_{\mathrm{AP}} \\
\left(\mathrm{s}^{-1}\right) \\
\end{array}$ & $\begin{array}{l}\mathrm{A}_{\mathrm{BP}} \\
(\%) \\
\end{array}$ & $\begin{array}{l}k_{\mathrm{BP}} \\
\left(\mathrm{s}^{-1}\right) \\
\end{array}$ \\
\hline susp & 9,1 & $1,5 \mathrm{E}+4$ & 7,3 & 4699 & 16,4 & 2,4 & 8,3 & 81,3 & 0,56 \\
\hline glass & 12,5 & $1,7 \mathrm{E}+4$ & 9,3 & 448 & 21,8 & 71,8 & 8,5 & 6,5 & 0,89 \\
\hline $\begin{array}{l}\text { ITO } \\
771 \\
\end{array}$ & n.r. & & 39,9 & 1711 & 39,9 & 53,1 & 9,9 & 9,1 & 1,92 \\
\hline $\begin{array}{l}\text { ITO } \\
860 \\
\end{array}$ & n.r. & & 11,6 & 868 & 11,6 & 82,7 & 10 & 5,7 & 0,86 \\
\hline
\end{tabular}

Az 18. ábrán szereplő abszorpciós görbék illesztési paraméterei 


\subsection{Elektromos mérések ITO/RC kompoziton}

Az RC és az ITO közötti kapcsolat jobb megértése érdekében fénygerjesztés hatására bekövetkező vezetőképességváltozás méréseket hajtottam végre. A mérések 4 pontos elvezetésben $10 \mathrm{~mA}$ konstans áram alkalmazásával történtek. A rendszer gerjesztését egy fehér fényű lámpa fényéből $400 \mathrm{~nm}$ levágási hullámhosszú aluláteresztő szürő segítségével állítottam elö, mely mind az RC-ot mind az ITO-t képes gerjeszteni.

Amennyiben magát az ITO-t világítottam meg folytonos kék fény segítségével, a lámpa bekapcsolását követően az ITO ellenállásának csökkenését tapasztaltam (19. ábra). A felületre RC-ot rétegezve a RC jelenléte kompenzálta a fénygerjesztést követő ellenállás csökkenést, mely egy bizonyos koncentrációt követően telítési szintet ért el (20. ábra). A telítési szintet követően a koncentrációt tovább növelve az ellenállás változása is tovább növekedett. Ebben a tartományban a változás jó egyezést mutat azzal az esettel, mint amikor fotokémiailag inaktív klorofillt rétegezünk a felületre azonos koncentrációban, mint amennyit a fehérje tartalmaz. Amennyiben csak klorofill van a felszínre rétegezve, a gerjesztési energia hö formájában jelenik meg, ebben az esetben az ellenállásváltozás jó egyezést mutat a hő hatására bekövetkező ellenállás változással [Nagy és mtsai., 2001]. Az ITO hö hatására bekövetkező ellenállás növekedését egy korábbi publikációnkban már közöltük [Hajdu és mtsai., 2011], mely jó egyezést mutat az itt kapott eredményekkel. Ezek alapján megállapítható, hogy a klorofill/ITO rendszer fénnyel való gerjesztést követő ellenállásváltozása a hőenergia disszipációjának tudható be. Ettől eltérően, amennyiben fehérjét rétegezünk a felszínre a klorofill helyett, a mért görbe nem egyfázisú. A gerjesztőfény $\mathrm{P}^{+} \mathrm{Q}^{-}$töltéspárt hoz létre a fehérjén belül, valamint gerjeszti az ITO-t is. A keletkező gerjesztett elektronok és a fehérjén belüli töltéspár közti kölcsönhatás az ellenállás megnövekedésében nyilvánul meg. Amennyiben a reakciócentrum fehérjét egy $10 \mathrm{~nm}$ átméröjü gömbbel közelítjük, a telítési szintnél mért fehérje mennyisége jó egyezést mutat egy monoréteges borítottsággal szoros illeszkedést feltételezve. Amennyiben a fehérje mennyisége ettől több, többrétegü borítottság alakul ki és az ITO-val közvetlenül nem érintkező rétegek hatása mindinkább hőeffektusként jelenik meg. 


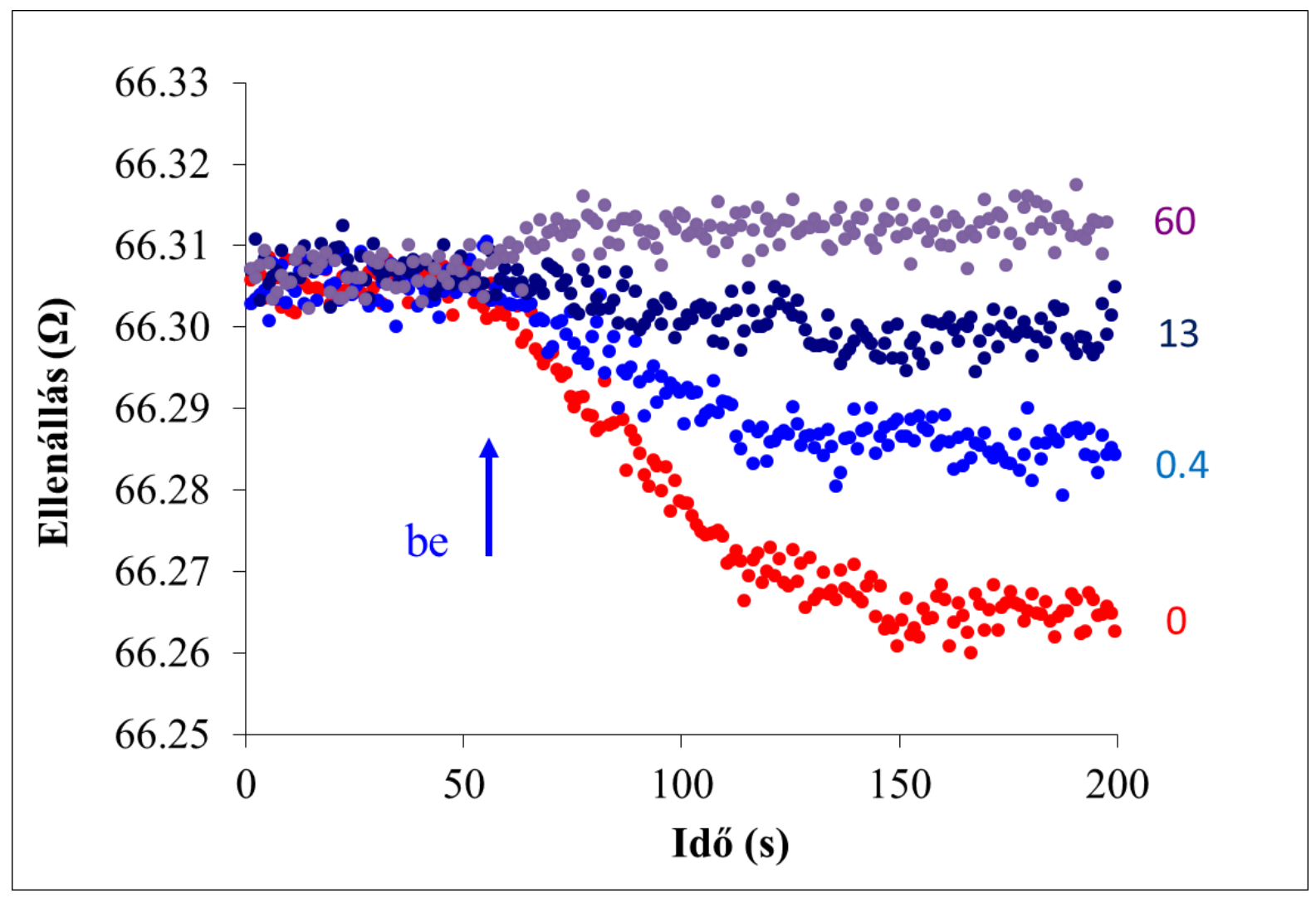

19. ábra

ITO ellenállása fénygerjesztést követően RC nélkül és különböző koncentrációjú RC jelenlétében. (A számok az ábrán koncentrációértékeket jelölnek $\mu \mathrm{M}$ egységben). A fény bekapcsolását a nyíl jelzi. A megvilágítás kék fényhasználatával folytonosan történt, $3,2 \mathrm{Wcm}^{-2}$ teljesítménnyel. 


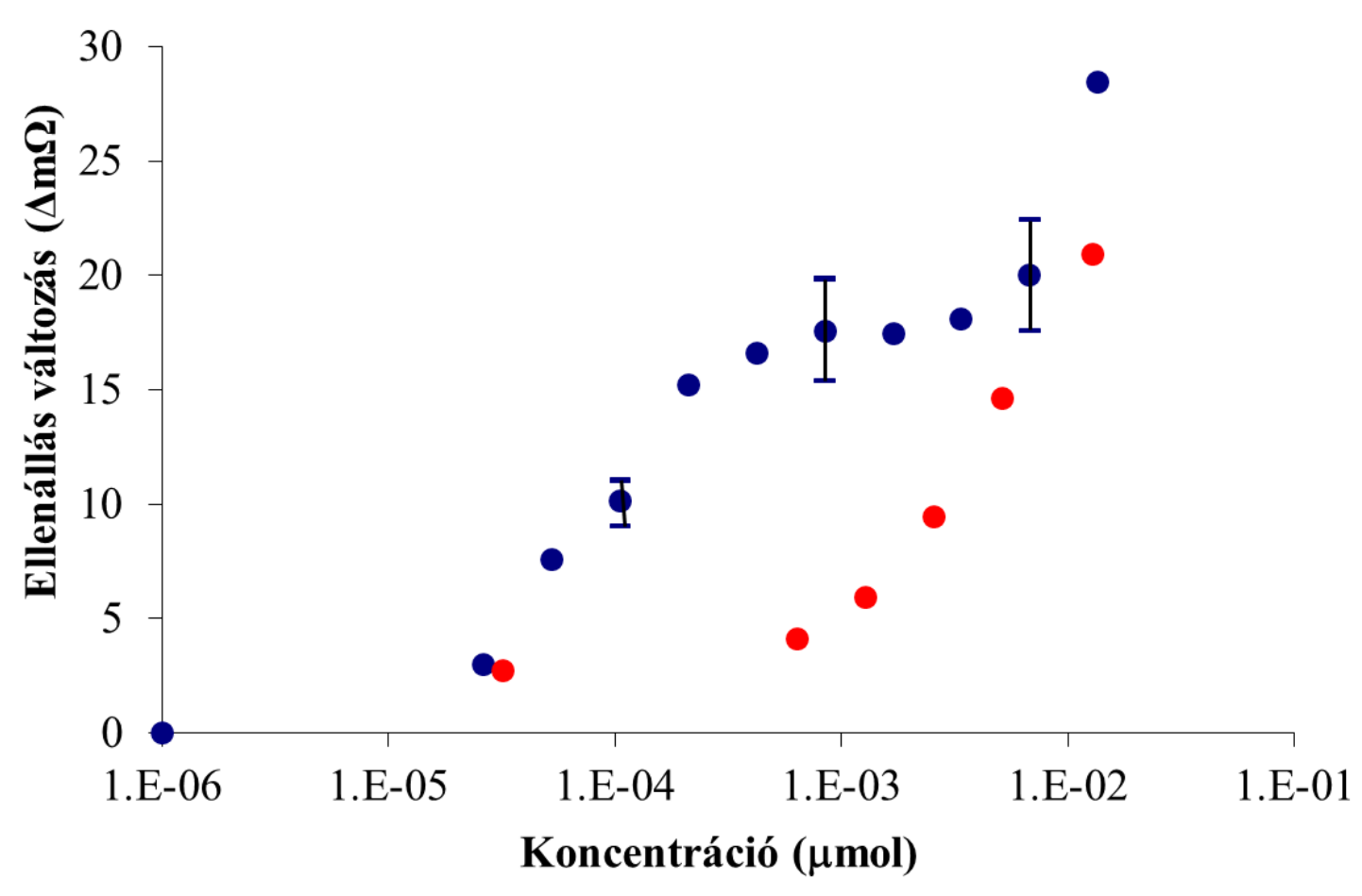

20. ábra

ITO fényindukált ellenállásváltozása a RC (kék kör) és a bakterioklorofill (piros kör) koncentrációjának függvényében

\subsection{ITO/MWCNT/RC fotokémiája elektrokémiai cellában}

A komplex elektrokémiai viselkedésének vizsgálatai nyitott áramköri potenciálon zajlottak. Miután a rendszer elérte a megvilágítás nélkül, sötétben mérhető egyensúlyi potenciált, a fotokémiai reakció kiváltását lézerdióda (Roitner Lasertechnik GmbH; $808 \mathrm{~nm}$; 2 W; folytonos üzem) vagy fehér fényủ halogén lámpa fényével oldottam meg. A 21. és 22. ábra az ITO/MWCNT/RC komplex fotokémiai aktivitását mutatja fénnyel való gerjesztés hatására. Külső elektrondonor és -akceptor-típusú mediátor jelenlétében a RC fotokémiája folyamatos átfordulást mutat. Az elektron elszállításáról a redukált (és egyúttal protonált) kinon gondoskodik, az oxidált primer donoron $\left(\mathrm{P}^{+}\right)$jelentkező ,hiányelektront” pedig ferrocénmolekula pótolja. Donorként 
ferrocén, míg akceptorként UQ-0 (2,3-dimetoxi-5-metil-1,4-p-benzokinon) vízben oldékonyabb kinont alkalmaztam. A mérést $0,1 \mathrm{M} \mathrm{NaCl}$ jelenlétében és sómentes körülmények között is végrehajtottam.

A hozzáadott ferrocén $(60 \mu \mathrm{M})$ nem befolyásolja a fotoáram karakterisztikáját $0,1 \mathrm{M}$ só jelenlétében. A jelenségre többféle magyarázat is adható. Lehetséges, hogy a kémiai kötést követően a fehérje aktív felszíne nem hozzáférhető a ferrocén számára, vagy az elektront az elektród szolgáltatja a RC fehérjének. Magyarázatként szolgálhat az is, hogy a magas sókoncentráció elektrosztatikusan gátolja a ferrocén bekötődését. Abban az esetben, ha a akceptoroldali elektrontranszportot UQ-0 mediátrorral állítottam vissza, jelentős fotoáramnövekedés volt megfigyelhető. Megállapítható továbbá az is, hogy UQ-0 jelenlétében a gyors ugrást egy lassú növekedés követ. A gyors fázis amplitúdója hozzávetőleg a kinonmentes minta esetében mérttel egyezik meg $(\approx 0,3 \mu \mathrm{A})$, csak kismértékü növekedés figyelhető meg.

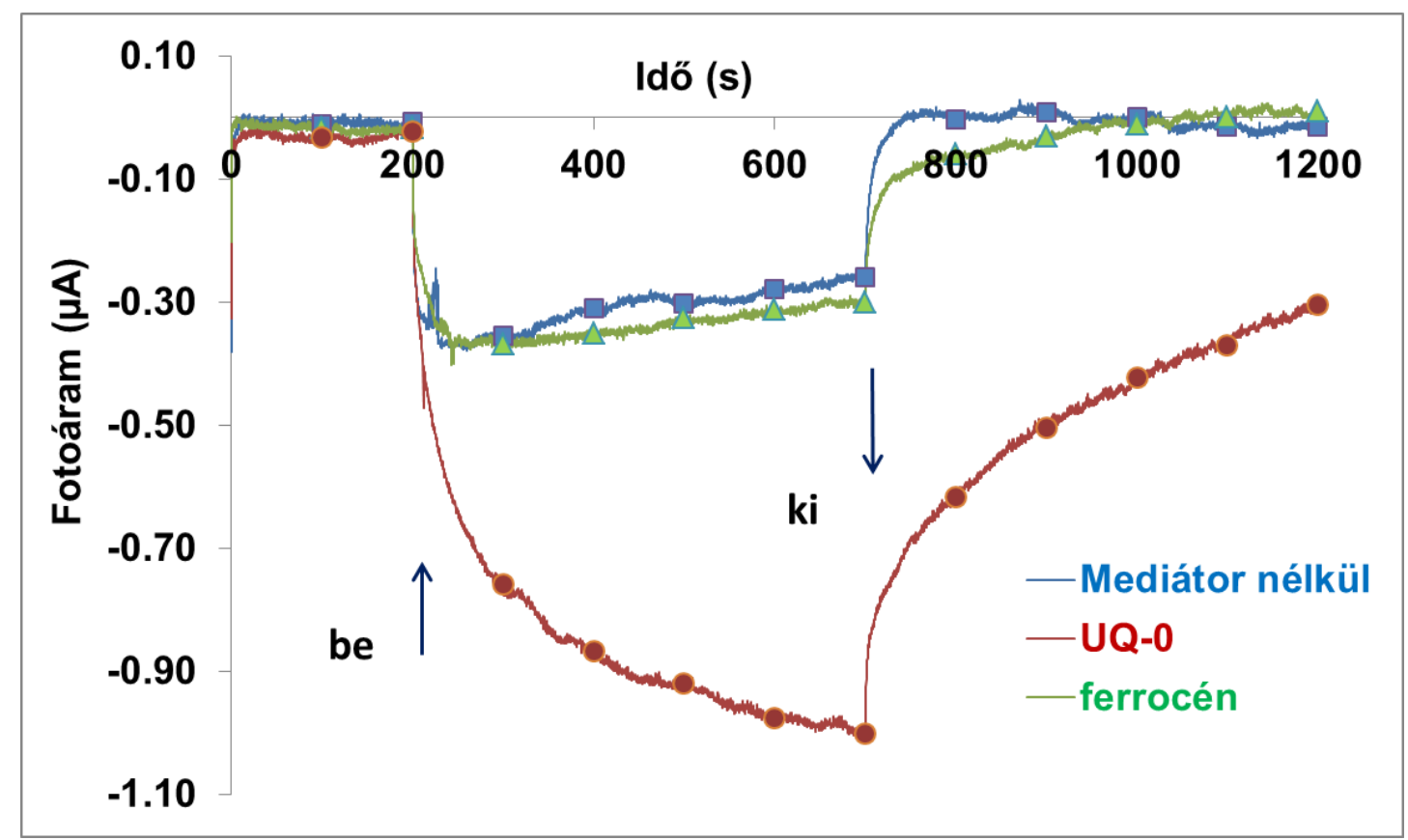

\section{1. ábra}

Fénnyel való gerjesztés hatására keletkező fotoáram elektrokémiai cellában, magas ionerősségü elektrolitban. Munkaelektródként ITO-ra rögzített MWCNT/RC komplexet használtam, mediátorként kinont (piros kör) és ferrocént (zöld háromszög) alkalmaztam, elektrolitként 0,1Mos $\mathrm{NaCl}$ szolgált. A gerjesztő fény be $(\uparrow)$ és kikapcsolását $(\downarrow)$ nyilak jelzik. 
Kis ionerősségű közegben (amennyiben nem adunk sót a rendszerhez és a reakcióelegy csak $20 \mu \mathrm{M}$ TRIS-t tartalmaz), a ferrocén jelenléte is eredményez fotoáram növekményt, miközben a beállási idő jelentősen lerövidül (22 ábra).

Az eredmények alapján megállapítható, hogy a kémiai kötést követően a komplex megtartja fotokémia aktivitását, továbbá mind a donor-, mind az akceptoroldal hozzáférhető a mediátorok számára. A hozzáférhetőséget az oldat ionerőssége befolyásolja. A magas ionerősség esetén tapasztalható lassú beállási idő a lassú elektródpolarizációnak köszönhető, amely szintén az ionerősség függvénye.

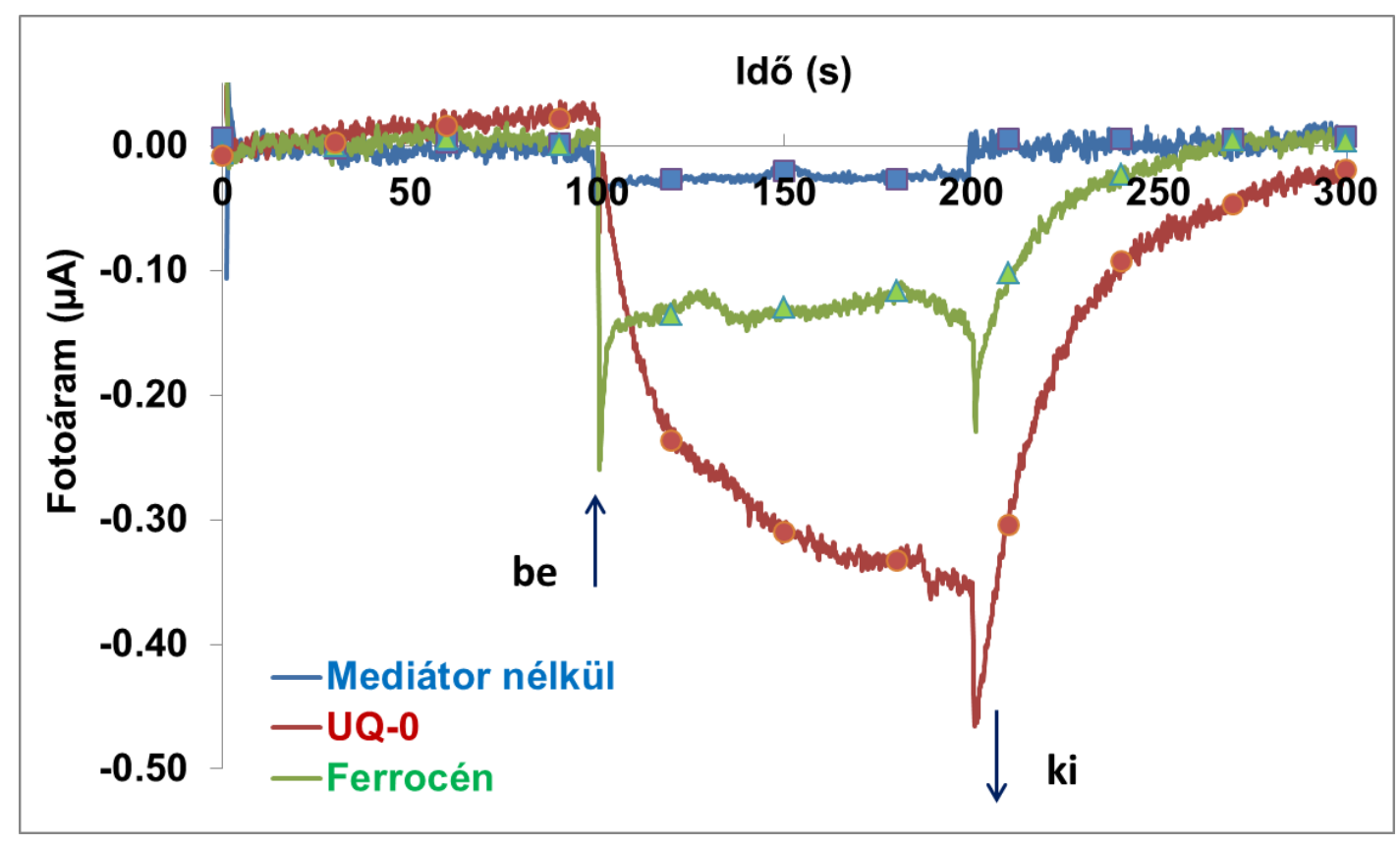

22. ábra

Fénnyel való gerjesztés hatására keletkező fotoáram elektrokémiai cellában, alacsony ionerősségü közegben. Munkaelektródként ITO-ra rögzített MWCNT/RC komplexet használtam, mediátorként kinont (piros kör) és ferrocént (zöld háromszög) alkalmaztam $20 \mu \mathrm{M}$ TRIS oldatban. A gerjesztő fény be $(\uparrow)$ és kikapcsolását $(\downarrow)$ nyilak jelzik. 


\subsection{ITO/MWCNT/PTAA/RC fotokémiája elektrokémiai cellában}

A RC rögzítéséhez vezető polimert is alkalmaztam a MWCNT felületén. A módszer előnye, hogy a PTAA kötőszerként is viselkedik és az elektronok vezetésében is részt tud venni ezáltal segítve a kapcsolatot a RC és az elektródként szolgáló ITO között. A mérést az előbbiekhez hasonlóan háromelektródos rendszerben végeztem, ellen és referencia elektródként szintén platinát és $\mathrm{Ag} / \mathrm{AgCl}$ elektródot alkalmaztam. Megállapítható, hogy a fénnyel való gerjesztés hatására keletkező fotoáram mediátor nélkül is jelentősen megemelkedik a PTAA kötőszer alkalmazása esetén az EDC/NHS módszerrel kapott mintán mérthez képest (kb. 0,3 $\mu \mathrm{A}$ röl $1 \mu$ A-re), míg UQ-0 mediátor hozzáadásával közel egy nagyságrendnyi növekedés tapasztalható (kb. $1 \mu \mathrm{A}$-ről $7 \mu \mathrm{A}-\mathrm{re})$ (23. ábra).

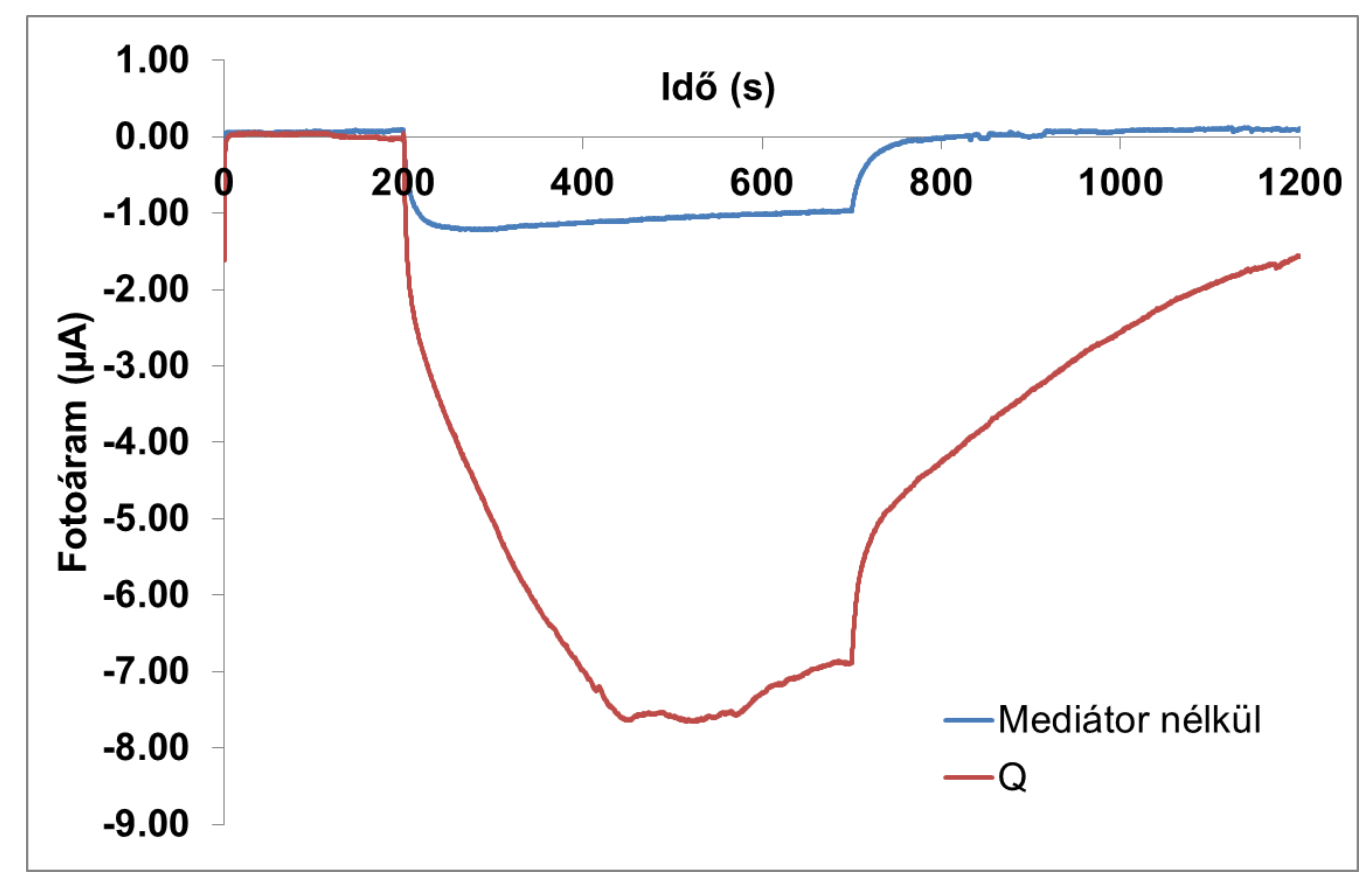

23. ábra

ITO/MWCNT/PTAA/RC kompozit által generált fotoáram. Az elektrokémiai cellát háromelektródos elrendezésben használtam, ahol munkaelektródként ITO-t alkalmaztam felületén MWCNT/PTAA/RC kompozittal, ellenelektródként platina, referenciaként pedig $\mathrm{Ag} / \mathrm{AgCl}$ volt a rendszerben. Mediátorként UQ-0 szolgált. 


\subsection{Fotoáram keltése RC-mal érzékenyített vezető polimer rétegstruktúrában}

Az elektrokémiai cellában végrehajtott mérések mellet a RC érzékenyítő hatását száraz körülmények között is tanulmányoztam. Ennek érdekében a fehérjét egy szerves fényérzékeny rendszerbe helyeztem. Számos esetben igazolást nyert az a tény, hogy a RC a fotokémiai/-fizikai aktivitását inorganikus hordozókon is megörzi akár oldószermentes, száraz környezetben is (általam bemutatott ITO, boroszilikát üveg, szén nanocső [Hajdu és mtsai. 2011, Szabó és mtsai. 2013, Dorogi és mtsai. 2006]). Továbbá, a szén nanocsövek képesek a RC által keltett töltéspár stabilizációjára, mely a fehérje és az szervetlen hordozó közti redox kapcsolatban nyilvánul meg.

A 24. ábra a minta áram/feszültség karakterisztikáját mutatja. A fehérjét nem tartalmazó minta önmaga is generál fotoáramot, melyet a RC hozzáadása jelentős mértékben megnövel. A minta előfeszítés nélkül is generál fotoáramot/fotofeszültséget, tehát napelemként is müködik (25. ábra). Megvilágítás hatására mind az áram mind a feszültség gyorsan megjelenik, majd egy lassabb változás is megfigyelhető, amely a mi értelmezésünk szerint valószínüleg a minta melegedésének tudható be. A változás reprodukálhatóan követi a fény be és kikapcsolását, amint az a 25. ábrán látható.

Annak érdekében, hogy igazoljam, hogy az áram a RC-ban lezajló fotokémiai/fotofizikai változások eredménye, a mintát különböző hullámhosszú fénnyel világítottam meg. A RC a vörös tartományban jelentős elnyelést mutat, míg a zöld fényt kevésbé nyeli el. A fehér fényü gerjesztőfényböl a különböző hullámhossztartományokat optikai szürők segítségével választottam ki, az alkalmazott szürők transzmissziós spektruma a 26. ábrán látható. Megállapítottam, hogy habár a kompozit jelentős elnyelést mutat a spektrum zöld tartományában is, a fotoáram abszolút értéke kisebbnek bizonyult, mint vörös fénnyel történő gerjesztés esetén. Továbbá, az érzékenyített és RC-ot nem tartalmazó minta fotoáramának aránya is kisebb volt zöld fénnyel történő gerjesztés esetén $(1,3)$ mint vörös fényt alkalmazva $(2,1)$. A 27 . ábra arra enged következtetni, hogy a növekményt a RC által generált áram szolgáltatja. 


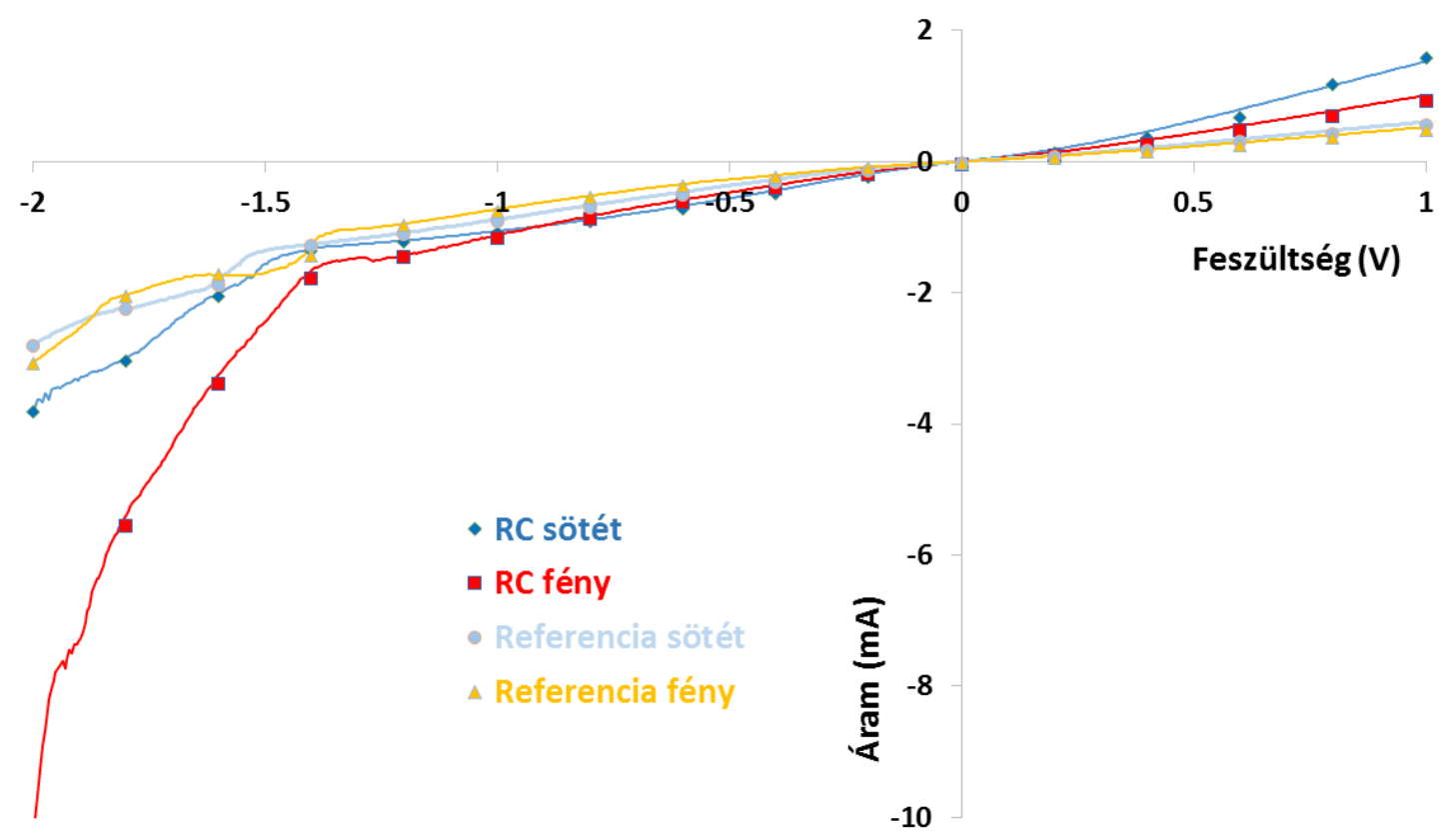

24. ábra

Aktív rétegként PEDOT:PSS és P3HT/MWCNT/RC komplexet tartalmazó szerves napelem áram/feszültség karakterisztikája. Referenciaként RC-ot nem tartalmazó minta szolgált. A mérés száraz körülmények között, $4 \mathrm{mWcm}^{-2}$ teljesítményü fehér fényü gerjesztő fény alkalmazásával történt, $50 \mathrm{mVcm}^{-1}$ szkennelési sebesség mellett. 

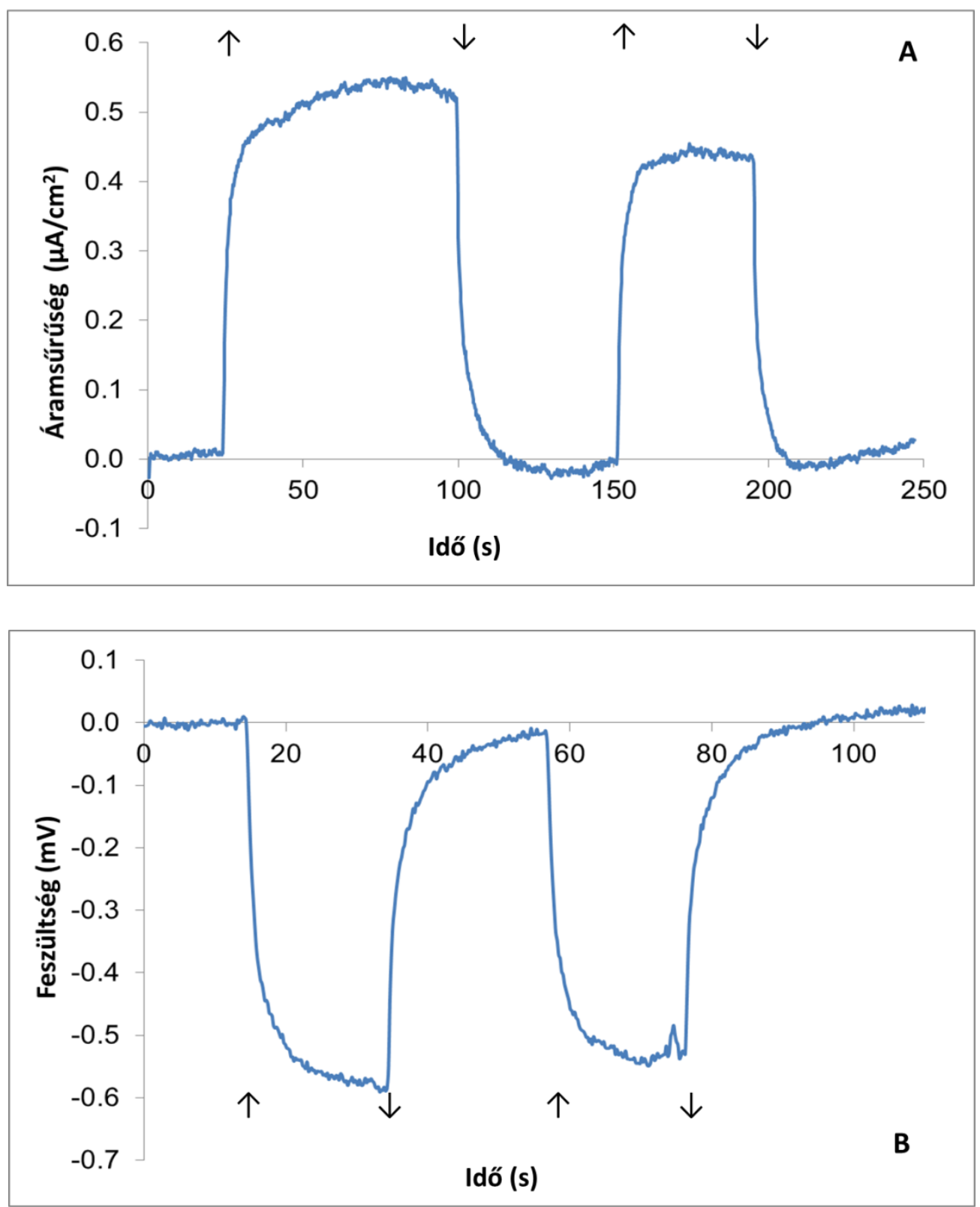

25. ábra

RC-mal érzékenyített szerves optoelektronikai eszköz fényindukált fotoáramsürüsége (A) és feszültsége (B). A gerjesztő fény be $(\uparrow)$ és kikapcsolását $(\downarrow)$ nyilak jelzik. A mérés száraz körülmények között, külső feszültség alkalmazása nélkül zajlott, $4 \mathrm{mWcm}{ }^{-2}$ teljesítményü fehér fényủ gerjesztő fény alkalmazásával, melyet optikai szál segítségével juttattam a mintára. 


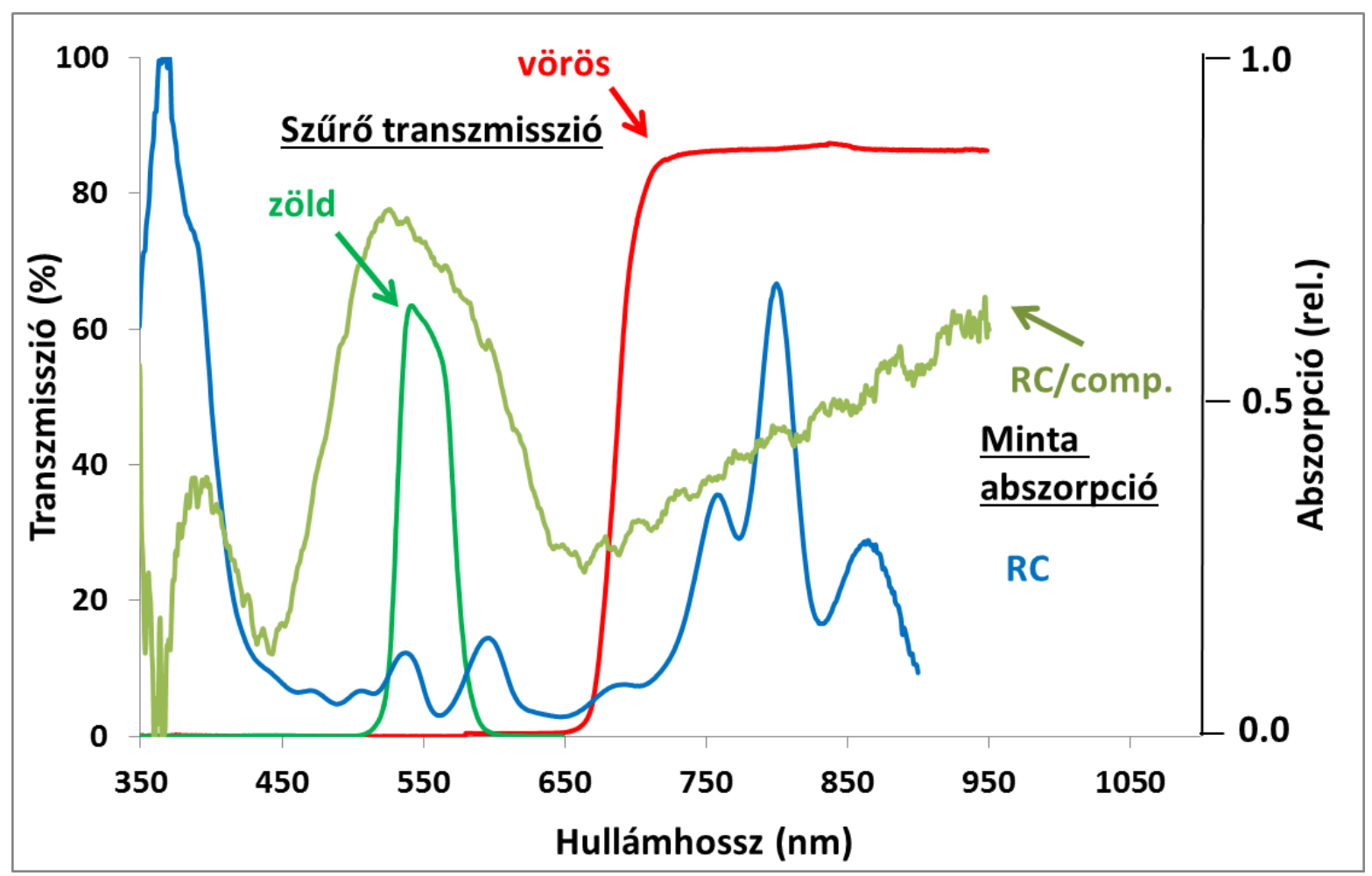

26. ábra

Szelektív gerjesztésre használt zöld és vörös szürők transzmissziós, valamint a szárított komplex (RC/comp.) és RC (LDAO- tartalmazó oldatban mért) abszorpciós spektruma. Az abszorpciót relatív egységekben adtam meg a jellemző abszorpciós sávok jobb láthatóságának érdekében. 


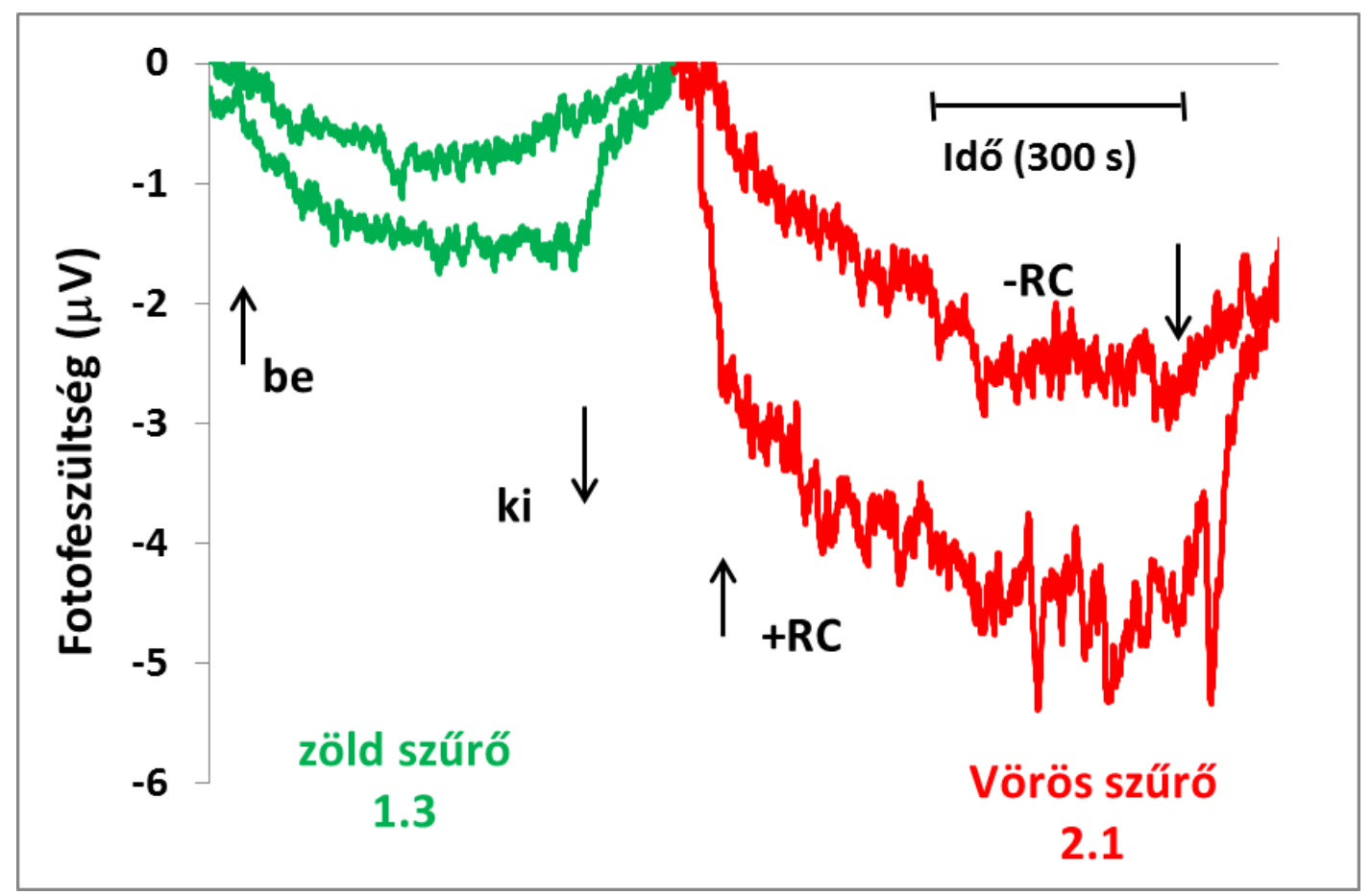

27. ábra

RC érzékenyített és RC mentes optoelektronikai eszköz fotofeszültsége zöld és vörös fénnyel való gerjesztése esetén. A szürök karakterisztikái a 26. ábrán láthatóak. A zöld és a vörös fényü megvilágítás teljesítménysürüsége azonos értékre normált $\left(1 \mathrm{mWcm}^{-2}\right)$. A gerjesztő fény be $(\uparrow)$ és kikapcsolását $(\downarrow)$ nyilak jelzik. A számok $(1,3$ és 2,1$)$ a fotofeszültség arányának változását jelzik a RC érzékenyített és RC mentes minták között zöld és vörös fénnyel történő gerjesztés esetén.

\subsection{Szén nanocsövek izotópanalitikai jellemzése}

\subsubsection{Stabilizotóp tartalom karakterizálása}

Munkám során kilenc különböző MWCNT mintát vizsgáltam izotópanalitikai módszerekkel. A minták CCVD módszerrel készültek, a szintézis paramétereit a 2. táblázat foglalja össze. 
A szén nanocső minták tömegspektrumait jól ismert szén- és nitrogéntartalmú referenciaanyagok spektrumaival hasonlítottam össze. A különbözö minták nitrogéntartalma 2,6 és 5,3 m/m \% között alakult (minták: I/1466/9,10,13,14). Széntartalom tekintetében a minták között jelentősebb eltérések voltak tapasztalhatóak, az értékek 33 és 67 m/m \% között változtak. Nitrogén dópolt mintákban a $\delta^{15} \mathrm{~N}$ tartalom 4,25 \%o és 6,09 \%o míg a stabil szénizotóp aránya 20,57 \%o and -29,57 \%o között változott.

Tiofén használata esetén azt tapasztaltuk, hogy a szintézis magasabb hőmérséklete magasabb széntartalmat eredményezett, viszont ez nem járt együtt magasabb heteroatom tartalommal. A kén beépülése $800^{\circ} \mathrm{C}$-on alacsonyabbnak bizonyult.

\begin{tabular}{|c|c|c|c|c|c|}
\hline \multirow[b]{2}{*}{$\begin{array}{c}\text { Minta- } \\
\text { azonosító }\end{array}$} & \multicolumn{5}{|c|}{ Szintézis-körülmények } \\
\hline & $\begin{array}{c}\text { Heteroatom } \\
\text { típusa }\end{array}$ & $\begin{array}{l}\text { Szintézis } \\
\text { módszere }\end{array}$ & Heteroatom-forrás & $\begin{array}{l}\text { Reakció idő/ } \\
\text { Dópolási idő } \\
\text { [perc] }\end{array}$ & $\begin{array}{c}\mathrm{T} \\
{\left[{ }^{\circ} \mathrm{C}\right]}\end{array}$ \\
\hline $\mathrm{I} / 1466 / 1$ & $\bar{S}$ & buborékoltatás & tiofén & $30 / 30$ & 700 \\
\hline $\mathrm{I} / 1466 / 2$ & $S$ & buborékoltatás & tiofén & $30 / 30$ & 800 \\
\hline $\mathrm{I} / 1466 / 9$ & $\mathrm{~N}$ & injektálás & TPA - ferrocén - aceton & $10 / 2$ & 720 \\
\hline $\mathrm{I} / 1466 / 10$ & $\mathrm{~N}$ & injektálás & TPA - ferrocén - aceton & $20 / 5$ & 720 \\
\hline $\mathrm{I} / 1466 / 11$ & $\mathrm{~N}$ & buborékoltatás & TPA & $40 / 40$ & 720 \\
\hline $\mathrm{I} / 1466 / 12$ & $\mathrm{~N}$ & buborékoltatás & TPA - aceton & $40 / 40$ & 720 \\
\hline $\mathrm{I} / 1466 / 13$ & $\mathrm{~N}$ & injektálás & TPA & $20 / 5$ & 720 \\
\hline $\mathrm{I} / 1466 / 14$ & $\mathrm{~N}$ & injektálás & TPA & $20 / 10$ & 720 \\
\hline $\mathrm{I} / 1466 / 15$ & $\mathrm{~N}$ & buborékoltatás & TPA & $40 / 40$ & 750 \\
\hline
\end{tabular}

2. táblázat

A vizsgált minták szintézis-körülményeinek összegzése. 
A buborékoltatásos eljárás kén dópolás esetén gyengébb eredményt hozott, mint nitrogén dópolás esetén, stabil nitrogén tartalom nem volt mérhető a 11, 12 és 15-ös minták esetén, habár a TEM felvételeken felfedezhető a nitrogén dópolás hatására megjelenő bambusz szerkezet. A 15ös minta esetén megállapítható, hogy növekvő szintézis hőmérséklet nem jár együtt magasabb nitrogén tartalommal. A 12-es minta esetén a buborékoltatáshoz használt oldat 1:9 arányban tartalmazott TPA-t és acetont, amely a heteroatom forrás megnövekedett illékonyságát eredményezte, de ez nem jár együtt jelentősebb nitrogén beépüléssel.

A tiofén és a TPA hatására történő dópolásbeli különbség magyarázható az anyagok szobahőmérsékleten mért eltérő gőznyomásával, melyek között két nagyságrendnyi különbség van (TPA 1,5 Hgmm, tiofén 79,7 Hgmm). Ennek következtében változtattunk a rendszerünkön és a buborékoltatást egy injektálásos módszerrel váltottuk fel.

Az injektálásos módszerrel készített nitrogénnel dópolt minták $(9,10,13,14)$ stabil nitrogénizotóp-aránya jelentősen magasabbnak adódott. A 13-as és 14-es minták esetén megállapítható, hogy a dópolási idő 5 percről 10 percre történő változtatása jelentős nitrogéntartalom növekedést eredményezett. Az irodalomból ismert, hogy a ferrocén képes gátolni a nitrogén beépülést [Yadav és mtsai. 2005], ennek igazolása érdekében a 9-es és 10-es minták esetén ferrocént adtunk a rendszerhez. A stabilizotóp mérések igazolták a gátló hatást. 2 percnyi ferrocén hozzáadás még nem eredményez jelentős csökkenést, de 5 perc esetén már csak fele annyi nitrogén épül be a struktúrába. A lecsökkent nitrogéntartalom hatása a kialakult szerkezetben is megfigyelhetö (3. táblázat). 


\begin{tabular}{|c|c|c|c|c|c|c|c|c|}
\hline & $\delta^{15} \mathrm{~N}$ & \pm & & $\delta^{13} \mathrm{C}$ & & & $S$ & \pm \\
\hline $\begin{array}{c}\text { Minta- } \\
\text { azonosító }\end{array}$ & $\begin{array}{c}\text { (\%o, } \\
\text { levegő) }\end{array}$ & $\begin{array}{c}(\%, \\
\text { levegő) }\end{array}$ & $\begin{array}{l}\text { nitrogén } \\
(\mathrm{m} / \mathrm{m} \%)\end{array}$ & $\begin{array}{c}(\%, \\
\text { VPDB })\end{array}$ & $\begin{array}{c} \pm(\%, \\
\text { VPDB) }\end{array}$ & $\begin{array}{c}\text { szén } \\
(\mathrm{m} / \mathrm{m} \%)\end{array}$ & $(\mathrm{mg} / \mathrm{kg})$ & $(\mathrm{mg} / \mathrm{kg})$ \\
\hline $\mathrm{I} / 1466 / 1$ & - & - & - & $-26,79$ & 0,16 & 33,30 & 318 & 3 \\
\hline $\mathrm{I} / 1466 / 2$ & - & - & - & $-25,89$ & 0,04 & 41,94 & 256 & 4 \\
\hline $\mathrm{I} / 1466 / 9$ & 6,09 & 0,03 & 5,30 & $-24,22$ & 0,09 & 66,43 & - & - \\
\hline $\mathrm{I} / 1466 / 10$ & 4,25 & 0,33 & 2,61 & $-27,55$ & 0,11 & 66,35 & - & - \\
\hline $\mathrm{I} / 1466 / 11$ & - & - & - & $-25,05$ & 0,16 & 45,41 & - & - \\
\hline $\mathrm{I} / 1466 / 12$ & - & - & - & $-26,03$ & 0,24 & 41,34 & - & - \\
\hline $\mathrm{I} / 1466 / 13$ & 5,13 & 0,01 & 2,84 & $-29,57$ & 0,08 & 58,79 & - & - \\
\hline $\mathrm{I} / 1466 / 14$ & 5,96 & 0,39 & 3,47 & $-29,50$ & 0,27 & 55,78 & - & - \\
\hline $\mathrm{I} / 1466 / 15$ & - & - & - & $-20,57$ & 0,04 & 37,56 & - & - \\
\hline
\end{tabular}

3. táblázat

A különböző szén nanocső minták stabil nitrogén, kén és széntartalma. A mintaazonosítók a 2. táblázatban szereplő mintákat jelölik. VPDB (Vienna Pee Dee Belemnite) a mérés során használt standardot jelöli. 


\subsubsection{Szénizotóp tartalom karakterizálása}

A dolgozatomban radiokarbon tartalom jellemzésére a modern szén százalék (pMC: percent modern carbon) egységet fogom alkalmazni, ami definíció szerint

$$
p M C=\frac{\mathrm{A}_{S N}}{\mathrm{~A}_{O N}} * 100 \%
$$

ahol $A_{\mathrm{SN}}$ a minta specifikus aktivitása, $A_{\mathrm{ON}}$ pedig a NIST-SRM-4990c oxálsav-standard aktivitását jelöli.

Munkám során vizsgáltam a minták szénizotóp tartalmát is. Két minta esetén a ${ }^{14} \mathrm{C}$ tartalom feloldási határ alatti volt (I/1466/1 és 2). A szén kitermelési hatásfoka jelentős fluktuációt mutatott a különbözö minták esetén. A ${ }^{14} \mathrm{C}$ tartalom szintén széles intervallumban változott (3,0-tól 34,1 pMC-ig). Izotópanalitika kutatások igazolták, hogy a felhasznált prekurzorok jelentősen befolyásolják a keletkező szén nanocsövek tulajdonságait. A kötődött fehérje mennyiségének pontos meghatározásához szükséges, hogy a szén nanocső és fehérje ${ }^{14} \mathrm{C}$ izotóptartalma jelentősen eltérjen. A fehérje ${ }^{14} \mathrm{C}$ tartalmát a baktérium táplálékául szolgáló anyagok szénizotóp aránya határozza meg. A szén nanocső kiválasztását a ${ }^{14} \mathrm{C}$ tartalom, nem pedig a kitermelési hatásfok határozta meg. Mivel a fehérje ${ }^{14} \mathrm{C}$ tartalma viszonylag magas volt, ezért szükségszerüen az alacsony izotóptartalmú szén naocsövek bizonyultak megfelelönek további felhasználásra (I/1466/11 és 12). Kompozit készítéséhez a I/1466/11 mintát használtam, melynek a felületét a kémiai rögzítés érdekében a preparálást megelőzően - $\mathrm{COOH}$ csoportokkal funkcionalizáltam (4. táblázat). 


\begin{tabular}{ccc}
\hline $\begin{array}{c}\text { Minta- } \\
\text { azonosító }\end{array}$ & $\begin{array}{c}\text { Kitermelési hatásfok } \\
{[\%]}\end{array}$ & $\begin{array}{c}{ }^{14} \mathrm{C} \text { tartalom } \\
{[\mathrm{pMC}]}\end{array}$ \\
\hline $\mathrm{I} / 1466 / 9$ & 56,0 & 18,0 \\
$\mathrm{I} / 1466 / 10$ & 44,0 & 6,2 \\
$\mathrm{I} / 1466 / 11$ & 63,0 & 4,0 \\
$\mathrm{I} / 1466 / 12$ & 73,0 & 3,0 \\
$\mathrm{I} / 1466 / 13$ & 59,0 & 13,6 \\
$\mathrm{I} / 1466 / 14$ & 58,0 & 13,4 \\
$\mathrm{I} / 1466 / 15$ & 33,0 & 34,1 \\
\hline
\end{tabular}

A MWCNT minták ${ }^{14} \mathrm{C}$ tartalma. A minta-azonosítók a 2. táblázatban szereplő mintákat jelölik.

\subsection{MWCNT/RC kompozit izotópanalitikai vizsgálata}

Annak érdekében, hogy a MWCNT/RC kompozitot kémiai rögzítéssel tudjam elöállítani, a szén nanocsöveket funkcionalizálni kellett, mely során $-\mathrm{COOH}$ csoportokat alakítottam ki a nanocsövek felületén. A kötést követöen fontos tudnunk azt, hogy a kialakított komplex milyen arányban tartalmazza a MWCNT hordozót és a rákötött fehérjét. Ezen arányt szénizotóp mérés segítségével határoztam meg. A mérés során meghatároztam a f-MWCNT ${ }^{\mathrm{COOH}}$, RC és $\mathrm{f}$ $\mathrm{MWCNT}^{\mathrm{COOH}} / \mathrm{RC}{ }^{14} \mathrm{C}$ tartalmát, melyböl a f-MWCNT ${ }^{\mathrm{COOH}} / \mathrm{RC}$ arány származtatható. A reakciócentrum elsődleges szénforrása a Siström-medium (31,9 $\pm 0,5$ pMC, lásd táblázat), mely tápoldatként szolgál a fotoheterotróf növekedés során, de a légköri széndioxid ${ }^{14} \mathrm{C}$ tartalma $(\mathrm{kb}$. 100 pMC) is befolyásolhatja a ${ }^{14} \mathrm{C}$ tartalmát, mint másodlagos szénforrás (5. táblázat). 


\begin{tabular}{|c|c|c|c|c|}
\hline Minta megnevezése & $\begin{array}{c}\text { Minta tömege } \\
{[\mathrm{mg}]}\end{array}$ & $\begin{array}{c}\text { Széntartalom } \\
{[\mathrm{mg}]}\end{array}$ & $\begin{array}{c}\text { Kitermelés } \\
\text { hatásfoka [\%] }\end{array}$ & pMC \\
\hline Siström-medium & 9,93 & 2,07 & $21 \%$ & $31,9 \pm 0,5$ \\
\hline $\mathrm{RC}$ & 2,78 & 1,49 & $54 \%$ & $66,1 \pm 0,3$ \\
\hline f-MWCNT ${ }^{\mathrm{COOH}}$ & 1,15 & 0,85 & $74 \%$ & $6,4 \pm 0,1$ \\
\hline f-MWCNT ${ }^{\mathrm{COOH}} / \mathrm{RC}$ & 0,39 & 0,28 & $73 \%$ & $29,1 \pm 0,1$ \\
\hline $\mathrm{F}_{\mathrm{RC}}$ & \multicolumn{4}{|c|}{$38.0 \pm 2.0 \%$} \\
\hline
\end{tabular}

${ }^{14} \mathrm{C}$ szénizotóp mérések összegzése. A Siström-medium a baktériumok tápoldata, $\mathrm{RC}$ a preparált reakciócentrum fehérje, f-MWCNT ${ }^{\mathrm{COOH}}$ karboxilcsoporttal funkcionált szén nanocső, f$\mathrm{MWCNT}^{\mathrm{COOH}} / \mathrm{RC}$ pedig a szén nanocsőből és reakciócenrumból készített kompozitot jelöli.

A RC részarányát a ${ }^{14} \mathrm{C}$ egyensúlyi egyenlet alapján számoltam. A szénizotóp tartalom egy két komponensből álló elegy esetén az alábbi egyenlet segítségével adható meg:

$$
p M C_{f-M W C N T^{\text {соон } / R C}}=F_{R C} \cdot p M C_{R C}+\left(1-F_{R C}\right) \cdot p M C_{f-M W C N T^{\text {соон }}},
$$

ahol $\mathrm{pMC}_{\mathrm{RC}}, \mathrm{pMC}_{\mathrm{f}-\mathrm{MWCNT}}{ }^{\mathrm{COOH}}$ és $\mathrm{pMC}_{\mathrm{f}-\mathrm{MWCNT}}{ }^{\mathrm{COOH}}{ }_{\mathrm{RC}}$ a mért szénizotóp tartalma a $\mathrm{RC}$, f$\mathrm{MWCNT}^{\mathrm{COOH}}$ és f-MWCNT ${ }^{\mathrm{COOH}} / \mathrm{RC}$ komplexnek. A RC részarányát $\left(F_{\mathrm{RC}}\right)$ az egyenlet átrendezésével kapjuk:

$$
F_{R C}=\frac{p M C_{f-M W C N T^{\mathrm{COOH}} / R C}-p M C_{f-M W C N T^{\mathrm{COOH}}}}{p M C_{R C}-p M C_{f-M W C N T^{\mathrm{COOH}}}} \cdot 100 \%
$$

A 5. táblázat eredményeit felhasználva az egyenlet alapján $\mathrm{F}_{\mathrm{RC}}=38,0 \pm 2,0 \%$ széntartalomnak adódik. A RC molekulatömegét 80 kDa-nak, a széntartalmát pedig 48\%-nak (1PST.pdb 
molekulaszerkezet alapján) tekintve a f-MWCNT ${ }^{\mathrm{COOH}} / \mathrm{RC}$ tömegarány $53 \mathrm{~m} / \mathrm{m} \%$-nak adódik, abban az esetben, ha a fehérje EDC-NHS aktiválószer segítségével került rögzítésre.

\subsection{MWCNT/HRP kompozit izotópanalitikai vizsgálata}

Annak érdekében, hogy a MWCNT/HRP komplex enzimaktivitását megállapítsam, a komplexben lévő enzim mennyiségének meghatározása szükséges. Ennek érdekében ${ }^{14} \mathrm{C}$ izotóptartalom-meghatározást hajtottunk végre, mely során meghatároztam a MWCNT, a HRP és a MWCNT/HRP komplex ${ }^{14} \mathrm{C}$ tartalmát (pMC egységben).

A HRP részarányát az előző fejezetben már említett egyensúlyi egyenlettel határozhatjuk meg, ami jelen esetben, az alábbi formában adható meg:

$$
p M C_{f-M W C N T^{\mathrm{COOH}} / H R P}=F_{H R P} \cdot p M C_{H R P}+\left(1-F_{H R P}\right) \cdot p M C_{f-M W C N T^{C O O H}},
$$

ahol $\mathrm{pMC}_{\mathrm{HRP}}, \mathrm{pMC}_{\mathrm{f}-\mathrm{MWCNT}}{ }^{\mathrm{COOH}}$ és $\mathrm{pMC}_{\mathrm{f}-\mathrm{MWCNT}}{ }_{\text {/HRP }}^{\mathrm{COOH}}$ a mért szénizotóp tartalma a HRP, f$\mathrm{MWCNT}^{\mathrm{COOH}}$ és f-MWCNT ${ }^{\mathrm{COOH}} / \mathrm{HRP}$ komplexnek. A HRP részarányát $\left(F_{\mathrm{HRP}}\right)$ az egyenlet átrendezésével kapjuk:

$$
F_{H R P}=\frac{p M C_{f-M W C N T^{\mathrm{COOH}} / H R P}-p M C_{f-M W C N T^{\mathrm{COOH}}}}{p M C_{H R P}-p M C_{f-M W C N T^{C O O H}}} \cdot 100 \%
$$

Felhasználva a 6 . táblázatban összegzett mérési adatokat $F_{\mathrm{HRP}}=54 \%$ adódik. Ismerve a HRP molekulatömegét és széntartalmát $(44 \mathrm{kDa}, 45 \%$ széntartalom, a 1H5A.pdb molekulaszerkezet alapján), a komplexben a HRP/f-MWNT ${ }^{\mathrm{COOH}}$ tömegarány $72 \mathrm{~m} / \mathrm{m} \%$. 


\begin{tabular}{ccccc}
\hline Minta megnevezése & $\begin{array}{c}\text { Minta } \\
\text { tömege } \\
{[\mathrm{mg}]}\end{array}$ & $\begin{array}{c}\text { Széntartalom } \\
{[\mathrm{mg}]}\end{array}$ & $\begin{array}{c}\text { Kitermelés } \\
\text { hatásfoka } \\
{[\%]}\end{array}$ & pMC \\
\hline HRP & 3,0 & 1,3 & 43,1 & $145,2 \pm 0,4$ \\
$f-M_{W C N T}{ }^{C O O H}$ & 1,1 & 1,0 & 88,6 & $46,5 \pm 8,3$ \\
$f-M W C N T^{C O O H} / \mathrm{HRP}$ & 3,2 & 0,5 & 16,4 & $100,1 \pm 0,5$ \\
$\mathrm{~F}_{\mathrm{HRP}}$ & & & & \\
\hline
\end{tabular}

6. táblázat

${ }^{14} \mathrm{C}$ szénizotóp mérések eredményeinek összegzése. A HRP a tormaperoxidáz enzimet, fMWCNT $^{\mathrm{COOH}}$ a karboxil funkcionált szén nanocső, f-MWCNT ${ }^{\mathrm{COOH}} / \mathrm{HRP}$ pedig a szén nanocsőből és tormaperoxidázból készített kompozitot jelöli. 


\section{6. Összefoglaló}

Munkám során fehérjékből (bakteriális fotoszintetikus reakciócentrum és torma peroxidáz) és szervetlen hordozókból (indium-ón-oxid, dópolt és dópolatlan szén nanocsövek, vezető polimerek) készítettem bionanokompozit anyagokat és karakterizáltam azokat képalkotó eljárások, spektroszkópiai, elektrokémiai és tömegspektroszkópiai módszerek segítségével.

Rászárításos módszerrel rögzítettem RC-ot ITO felületére, majd mértem a rendszer ellenállásának változását fénnyel való gerjesztést követően a fehérje koncentrációjának függvényében. Megállapítottam, hogy az ellenállás változás nem egyfázisú, hanem telítési jellegü, mely telítődési jelenség összefüggő monoréteges borítottság esetén jelentkezik. A koncentráció növekedésével a jelenséget az elnyelt hő disszipációja miatti ellenállásváltozás dominálja, melyet referenciamérésekkel igazoltam megfelelő koncentrációjú tiszta klorofillt alkalmazva. A mérés érzékenysége igen jónak mondható, már néhány $\mathrm{pM} \mathrm{RC}$ is mérhető ellenállás változást eredményez a rendszerben.

Megmutattam továbbá azt is, hogy a RC száraz körülmények között is megörzi aktivitását, megfelelö körülmények között képes fény gerjesztés hatására fotoáramot generálni. Ennek érdekében ITO és ezüst elektródák között egy vezető polimer rétegstruktúrát alakítottam ki PEDOT:PSS és P3HT vezető polimerek alkalmazásával. Az RC-ot a P3HT rétegbe építettem be oly módon, hogy többfalú szén nanocsövek felületére növesztettem P3HT szálakat, majd ebbe a struktúrába ágyaztam a fehérjét. Szelektív gerjesztés segítségével megmutattam, hogy a megnövekedett fotofeszültség a fehérje aktív részvételének tudható be. Az RC-mal érzékenyített rendszert vörös fénnyel gerjesztve (ebben a tartományban az RC-nak jelentős elnyelése van) 2,1szeres, míg zöld fényt alkalmazva csupán 1,3-szoros fotofeszültség növekedést mértem.

A RC felhasználásával kialakított kompozit anyagokat vizes környezetben is tanulmányoztam. ITO/MWCNT/RC kompozitot egy háromelektródos elektrokémiai cellába helyeztem munkaelektródként, ahol ellenelektródként platinát, míg referenciaként $\mathrm{Ag} / \mathrm{AgCl}$ elektródot alkalmaztam. A rendszer fénnyel való gerjesztés hatására magas ionerősség esetén $(0,1$ $\mathrm{M} \mathrm{NaCl}$ jelenlétében) körülbelül $0,3 \mu \mathrm{A}$ fotoáramot generál, melyet a hozzáadott ferrocén mediátor nem befolyásol számottevő mértékben, ellenben az akceptorként alkalmazott UQ0 1 $\mu$ A-re növel. Alacsony ionerösség esetén (só mentes TRIS pufferben) mind a donor mind az 
akceptor típusú mediátor befolyásolja a fotoáram amplitúdóját. Habár azonos koncentrációk esetén itt az elért fotoáram nagysága kisebb $(\approx 0.3 \mu \mathrm{A})$ a felfutás sebessége jelentős mértékben megnö.

Amennyiben a szén nanocsőre nem EDC/NHS kötőszer alkalmazásával, hanem PTAA vezető polimer segítségével rögzítettem az RC fehérjét, további fotoáram növekedést értem el. A növekedés annak tulajdonítható, hogy a PTAA nem csak a rögzítést végzi, hanem az elektromos kapcsolatot is elősegíti az elektród és a fehérje között. Vezető polimer alkalmazásával körülbelül $7 \mu \mathrm{A}$ áramot értem el, ami közel egy nagyságrendnyi javulást jelent az EDC/NHS technikához képpest.

Munkám során meghatároztam az alkalmazott szén nanocső hordozók elemösszetételét, dópolt nanocsövek esetén a beépült kén és nitrogéntartalmat is, mely jelentősen befolyásolja a kialakult szén nanocső fizikai tulajdonságait.

Kompozit anyagok esetén az alkotók részarányának meghatározása igen fontos, viszont ez nanorendszerek esetén nem feltétlen egyszerű feladat. Ennek érdekében egy tömegspekrtometriás módszert alkalmaztam, mely a radiokarbon tartalom mérésén alapszik. Amennyiben az alkotók ${ }^{14} \mathrm{C}$ tartalma jelentősen eltér, az alkotók és a komplex radiokarbon tartalmának mérésével az alkotók részaránya számítható. Többfalú szén nanocsőből és reakciócentrum fehérjéből előállított kompozit esetén az RC/MWCNT arány $53 \mathrm{~m} / \mathrm{m} \%$-nak adódott.

Hasonló méréseket végeztem MWCNT/HRP kompozit esetén is, ahol szintén radiokarbon mérésekre alapozva a HRP/MWCNT arány $72 \mathrm{~m} / \mathrm{m} \%$-nak adódott. 


\section{Tudományos megállapítások}

Tudományos eredményeim alapján a következö megállapításokat teszem:

1. Indium ón oxid felületén rászárítással rögzítettem Rhodobacter sphaeroides bíborbaktériumból preparált fotoszintetikus reakciócentrum fehérjét (RC). Spektroszkópiai mérések segítségével megállapítottam, hogy a fehérje ezen környezetben akár száraz körülmények között is aktív marad. Fénnyel való gerjesztés esetén az ITO/RC komplex ellenállása lecsökken, melyet a két anyag közti elektrontranszferrel magyaráztam. A mérés érzékenysége igen jónak mondható, néhány pM RC is mérhető ellenállás változást eredményez. [Szabó és mtsai., Materials Science and Engineering C, 2012]

2. ITO és ezüst elektródok közé helyezett poli-3-hexiltiofénböl (P3HT) és poli(3,4etiléndietoxitiofén):polisztirén-szulfonátból (PEDOT:PSS) készített optoelektronikai eszköz reakciócentrum fehérjével érzékenyíthető, mely száraz körülmények között fénygerjesztés hatására megnövekedett fotoáramot mutat. Szelektív (a fehérjére jellemzö) fénnyel való gerjesztéssel igazoltam, hogy a növekmény a reakciócentrum érzékenyítő hatásából származik. [Szabó és mtsai., Phys. Status Solidi B, 2015]

3. ITO felületre többfalú szén-nanocsöveken keresztül rögzített reakciócentrumfehérje elektrokémiai cellában fotoáramot termel, mely elérheti az $1 \mu \mathrm{A}$ nagyságot is. A rendszerhez adott akceptor típusú mediátor (UQ-0) háromszorosára növeli a keletkezö fotoáram nagyságát. A cellában alkalmazott pufferoldatban a só jelenléte lassítja a fotoáram felfutását, továbbá az ionerősség befolyásolja a donoroldal redoxmediátorokkal való hozzáférhetőségét. [Szabó és mtsai., Phys. Status Solidi B, 2015] 
4. Reakciócentrum fehérje sikeresen rögzíthető többfalú szénnanocsövek felületére politiofén ecetsav (PTAA) vezető polimer segítségével. Megállapítottam, hogy a MWCNT/PTAA/RC komplexet ITO elektród felületére helyezve elektrokémiai cellában fénygerjesztés hatására a rendszer fotoáramot termel, melyet a hozzáadott mediátor jelentős mértékben befolyásol. A keletkező fotoáram közel egy nagyságrenddel nagyobb (7 $\mu \mathrm{A})$, mint a különböző nem vezető kötőszerek alkalmazásával kapott áram, mivel a PTAA a rendszerben nem csak a kötőszer szerepét látja el, hanem elősegíti az elektronok elektródhoz jutását is. [Szabó és mtsai., Phys. Status Solidi B, 2012; Szabó és mtsai., Nanoscale Research Letters, 2015]

5. Szén nanocsövekből és reakciócentrum fehérjéből készített komplexek összetételét vizsgáltam izotópanalitikai módszerek segítségével. Megállapítottam, hogy a módszer segítségével pontos kvantitatív információ nyerhető az összetételről. EDC-NHS aktiválószerrel kialakított kompozit esetén a RC/MWCNT aránya $53 \mathrm{~m} / \mathrm{m} \%$-nak adódott. [Szabó és mtsai., Radiocarbon, 2018]

6. Tormaperoxidáz enzimből (HRP) és szén nanocsövekből előállított kompozit összetétele ${ }^{14} \mathrm{C}$ izotópmérés segítségével meghatározható, melynek segítségével az enzim specifikus enzimaktivitása megadható. A HRP/MWCNT arány $72 \mathrm{~m} / \mathrm{m} \%$-nak adódott. [Magyar és mtsai., Journal of Nanomaterials, 2016] 


\section{Közlemények}

\section{A dolgozat alapjául szolgáló eredeti közlemények nemzetközi, referált folyóiratban}

1) Szabó T, Magyar M, Nemeth Z, Hernadi K, Endrodi B, Bencsik G, Visy C, Horvath E, Magrez A, Forro L, Nagy L, Charge stabilization by reaction center protein immobilized to carbon nanotubes functionalized by amine groups and poly(3-thiophene acetic acid) conducting polymer, Phys. Status Solidi B, 2012, 249(12):2386-2389. IF: 1,49

2) Szabó T, Bencsik G, Magyar M, Visy C, Gingl Z, Nagy K, Váró G, Hajdu K, Kozák G, Nagy L, Photosynthetic reaction centers/ITO hybrid nanostructure, Materials Science and Engineering:C, 2013, 33:769-773. IF: 2,74

3) Szabó T, Magyar M, Hajdu K, Dorogi M, Nyerki E, Tóth T, Lingvay M, Garab G, Hernádi K, Nagy L, Structural and functional hierarchy in photosynthetic energy conversion - from molecules to nanostructures, Nanoscale Research Letters ,2015, 10(1):458. IF: 2,58

4) Szabó T, Nyerki E, Tóth T, Csekő R, Magyar M, Horváth E, Hernádi K, Endrődi B, Visy C, Forró L, Nagy L, Generating photocurrent by nanocomposites based on photosynthetic reaction centre protein, Phys. Status Solidi B, 2015, 252:2614-2619. IF: 1,52

5) Magyar M, Rinyu L, Janovics R, Berki P, Hernádi K, Hajdu K, Szabó T, Nagy L, Real-Time Sensing of Hydrogen Peroxide by ITO/MWCNT/Horseradish Peroxidase Enzyme Electrode, Journal of Nanomaterials, 2016, Article ID 2437873, 11 pages. IF: 1,87

6) Szabó T, Janovics R, Túri M, Futó I, Papp I, Braun M, Németh K, Szekeres PG, Kinka A, Szabó A, Hernádi K, Hajdu K, Nagy L, Rinyu L, Isotope analytical characterization of carbon based nanocomposites, Radiocarbon, 2018, 60(4):1101-1114. IF: 1,81 (2017)

\section{Egyéb eredeti közlemények nemzetközi, referált folyóiratban}

1) Hajdu K, Szabó T, Magyar M, Bencsik G, Németh Z, Nagy K, Forró L, Váró G, Hernádi K, Nagy L, Photosynthetic reaction center protein in nano structures, Phys. Status Solidi B, 2011, 248(11):2700-2703. IF: 1,32

2) Magyar M, Hajdu K, Szabo T, Hernadi K, Dombi A, Horvath E, Forro L, Nagy L, Long term stabilization of reaction center protein photochemistry by carbon nanotubes, Phys. Status Solidi B, 2011, 248(11):2454-2457. IF: 1,32 
3) Magyar M, Hajdu K, Szabo T, Endrodi B, Hernadi K, Horvath E, Magrez A, Forro L, Visy C, Nagy L, Sensing hydrogen peroxide by carbon nanotube/horse radish peroxidase bionanocomposite, Phys. Status Solidi B, 2013, 250(12):2559-2563. IF: 1,65

4) Nagy L, Hajdu K, Torma S, Csikós S, Szabó T, Magyar M, Fejes D, Hernádi K, Kellermayer M, Horváth E, Magrez A, Forró L, Photosynthetic reaction centre/carbon nanotube bundle composites, Phys. Status Solidi B, 2014, 251(12): 2366-2371. IF: 1,47

5) Nagy L, Magyar M, Szabó T, Hajdu K, Giotta L, Milano F, Photosynthetic Machineries in Nano-Systems, Special Issue: "Sensors and transducers in the landscape of photosynthesis", Current Protein \& Peptide Science, 2014, 15(4): 363-373. IF: 3,15

6) Husu I, Magyar M, Szabó T, Fiser B, Gómez-Bengoa E, Nagy L, Structure and binding efficiency relations of QB site inhibitors of photosynthetic reaction centres, Gen. Physiol. Biophys., 2015, 34(2):119-33. IF: 0,89

7) Nagy L, Kiss V, Brumfeld V, Osvay K, Börzsönyi A, Magyar M, Szabó T, Dorogi M, Malkin $\mathrm{S}$, Thermal effects and structural changes of photosynthetic reaction centres characterized by wide frequency band hydrophone: Effect of carotenoids and terbutryne, Photochemistry and Photobiology, 2015, 91:1368-1375. IF: 2,01

8) Kinka A, Hajdu K, Magyar M, Mucsi L, Szabó T, Hernádi K, Horváth E, Magrez A, Forró L, Nagy L, Equilibrium concentration of singlet oxygen in photoreaction of reaction center/carbon nanotube bionanocomposites, Phys. Status Solidi B, 2015, 252(11) 24792484. IF: 1,52

9) Sarrai AE, Hanini S, Kasbadji MN , Tassalit D, Szabó T, Hernádi K, Nagy L, Using central composite experimental design to optimize the degradation of Tylosin from aqueous solution by photo-Fenton reaction, Materials, 2016, 9(6):428. IF: 2,65

10) Szabó T, Csekő R, Hajdu K, Nagy K, Sipos O, Galajda P, Nagy L, Sensing photosynthetic herbicides in electrochemical flow cell, Photosynthesis Research, 2016, 132(2):127-134. IF: 3,86

11) Hajdu K, Szabó T, Sarrai AE, Rinyu L, Nagy L, Functional Nanohybrid Materials from Photosynthetic Reaction Center Proteins, International Journal of Photoenergy, 2017, Article ID 9128291, 14 pages IF: 1,55 


\section{Konferenciakiadványok}

1) Sipka G, Szabó T, Zölei-Szénási R, Ványa M, Jakó M, Szkiva Z, Lang Á ,Nagy TD, Vadai G, Makan G, Dr. Borbás J, Dr. Fidrich M, Dr. Bitó T, Dr. Bilicki V, Bártfai G, Gyimóthy T, (2015) Magzati szívhang monitorozása és kiértékelése IPhone okostelefonnal, XXVIII. Neumann Kollokvium konferencia kiadványa, 2015, 169-173.

2) Szabó T, Sipka G, Borbás J, Schimert P, Fidrich M, Lang Á, Bilicki V, Rudas L, Mobil pletizmográf megvalósítása Iphone okostelefonon, XXVIII. Neumann Kollokvium konferencia kiadványa, 2015, 174-179.

3) Sarrai AE, Hanini S, Kasbadji MN, Tassalit D, Szabó T, Nagy L, Removal of Antibiotics From Aqueous Solution by Bioadsorbant, Csongrad County Group of the Hungarian Chemical Society, 2015.

4) Sarrai AE, Hanini S, Kasbadji MN, Tassalit D, Szabó T, Nagy, Melinda Magyar, Removal of Antibiotics From Aqueous Solution by Bioadsorbant, 21st International Symposium on Analytical and Environmental Problems, 2015.

5) Csekő R, Nyerki E, Birta B, Diblen HA, Cadirci BH, Szabó T, Magyar M, Hajdu K, Hernádi K, Nagy L, Bio-Nanocomposites - Optoelectronics, Energy Conversion, Biosensors, 21st International Symposium on Analytical and Environmental Problems, 2015.

\section{$\underline{\text { Referált folyóiratban megjelent konferencia absztraktok }}$}

1) Szabo T, Bencsik G, Kozak G, Visy C, Gingl Z, Hernadi K, Nagy K, Varo G, Nagy L, Interaction between photosynthetic reaction centers and ITO, Eur Biophys J., 2011, 40(1):S35-S241, P-532.

2) Hajdu K, Szabó T, Fejes D, Magyar M, Szegletes Z, Váró G, Horváth E, Magrez A, Hernádi K, Forró L, Nagy L, Carbon nanotube as functional matrix for bacterial photosynthetic reaction centers, Eur. Biophys J., 2013, 42(1):S1-236, 408.

3) Magyar M, Szabó T, Endrődi B, Hajdu K, Visy C, Szegletes Z, Váró G, Horváth E, Magrez A, Hernádi K, Forró L, Nagy L, Photocurrent generated by photosynthetic reaction centers/carbon nanotube/ITO bio-nanocomposite, Eur. Biophys J., 2013, 42. (1):S1-236, 411. 


\section{Könyvfejezet:}

Nagy L, Magyar M, Szabó T, Hajdu K, Giotta L, Dorogi M, Milano F, Fotoszintetikus reakcióentrumfehérje nano-rendszerekben, in Vincze J. ed. Selected articles III. Biophysics, 2013, 43:5-43.

\section{Előadások:}

1) Szabó T, Interaction between photosynthetic reaction centers and ITO, Swiss Contribution 7/2, Annual Progress Report, SZAB Székház Szeged, 2011. September 28.

2) Szabó T, Photocurrents generated by photosynthetic reaction centers in carbon nanotube/ITO nanostructures, SNSF Swiss National Science Foundation Valorization Meeting, Szeged, 5-8, June, 2013

3) Szabó T, Photocurrent Generated By Photosynthetic Reaction Center Based Nanocomposites, COST Action TD1102 Photosynthetic Proteins for technological applications: Biosensors and Biochips (PHOTOTECH) 2nd Plenary Workshop, Turkey Istanbul, 9-11 April 2014.

4) Szabó T, Conversion of visible light energy by carbon nanocomposites: energy harvesting and photocatalysis, Closing Conference of Swiss-Hungarian Cooperation Program (SH 7/2/20) entitled 2015. March 30-31.

5) Sarrai AE, Hanini S, Merzouk NK, Tassalit D, Szabó T, Nagy L, Magyar M, Factors influencing tylosin adsorption onto dehydrated wheat bran, XXXVIII. Kémiai előadói napok, 26-28, October, 2015, Szeged, Hungary.

6) Csekő R, Nyerki E, Birta B, Diblen HA, Cadirci BH, Szabó T, Magyar M, Hajdu K, Hernádi K, Nagy L, Bio-Nanocomposites - Optoelectronics, Energy Conversion, Biosensors, 21st International Symposium on Analytical and Environmental Problems, 28 September, 2015, Szeged, Hungary.

7) Szabó T, Bio-nankompozitok alkalmazása érzékenyített napelemekben, Magyar Biofizikai Társaság Kongresszusa, 2015 Augusztus 25-28., Budapest.

8) Magyar M, Szabó T, Nyerki E, Tóth T, Hajdu K, Lingvay M, Kinka A, Hernádi K, Nagy L, Fotoszintetikus reakciócentrum fehérje optoelektronika nano-hibrid rendszerekben, MKE 2. NEMZETI KONFERENCIA, 2015 Augusztus 31-szeptember 2, Hajdúszoboszló, Hungary.

\section{Konferencia poszterek:}

20 nemzetközi és 4 magyar konferencián bemutatott poszter. 


\section{Köszönetnyilvánítás}

Ezúton szeretnék köszönetet mondani, az Orvosi Fizikai és Orvosi Informatikai Intézet vezetőjének Prof. Bari Ferencnek, hogy lehetővé tette számomra, hogy tanszékén végezhessem tudományos munkámat.

Köszönettel tartozom témavezetőmnek Dr. Nagy Lászlónak, aki Bsc szakdolgozatom elkészítésétől kezdve folyamatosan támogatta és elősegítette szakmai előmenetelemet.

Köszönöm Laskayné Tóth Juditnak, a sejtnevelés valamit a preparálás során nyújtott segítségéért.

Köszönettel tartozom Dr. Magyar Melindának, Dr. Hajdu Katának, Dr. Kis Mariannak és Dr. Sipka Gábornak a kutatómunkám során nyújtott segítségért. Szeretném megköszönni az Orvosi Fizikai és Orvosi Informatikai Intézet minden munkatársának a munkám során nyújtott segítségét.

Köszönettel tartozom Prof. Dr. Hernádi Klárának és csoportjának a szén nanocsövek előállítása során nyújtott segítségéért.

Köszönet illeti Dr. Németh Zoltánt és Dr. Berki Pétert a mikroszkópiás vizsgálatok elvégzéséhez nyújtott nélkülözhetetlen segítségükért.

Köszönet illeti Dr. Szegletes Zsoltot az AFM mérések során nyújtott segítségükért.

Köszönöm Dr. Rinyu Lászlónak, Dr. Janovics, Túri Mariannának, Dr. Futó Istvánnak, Papp Istvánnak és Dr. Braun Mihálynak az izotópanalitikai mérések során nyújtott segítségét.

Fontos megemlítenem, hogy az alább felsorolt projektek nélkül nem jöhetett volna létre az általam elvégzett munka:

- Swiss Contribution (SH/7/2/20)

- Swiss National Scientific Fundation (SNSF IZ73Z0_128037/1)

- PHOTOTEHC COST Action (TD1102) 
- TÁMOP (TÁMOP-4.2.2.A-11/1/KONV-2012-0060)

- GINOP (GINOP-2.3.2-15-2016-00009) 


\section{Irodalomjegyzék}

Allen JP, Williams JC, Photosynthetic reaction centers. FEBS Lett., 1998, 438:5-9.

Bína D, Gardian Z, Vácha F, Litvín R, Supramolecular organization ofphotosynthetic membrane proteins in the chlorosome-containingbacterium Chloroflexus aurantiacus, Photosynth. Res., 2014, 122:13-21.

Blankenship RE, Early evolution of photosynthesis, Plant Physiol., 2010, 154:434-438.

Carmeli I, Frolov L, Carmeli C, Richter S, Photovoltaic activity of photosystem I-based selfassembled monolayer, Journal of the American Chemical Society, 2007, 129:12352-12353.

Chatzipetrou M, Milano F, Giotta L, Chirizzi D, Trotta M, Massaouti M, Guascito MR, Zergioti I, Functionalization of gold screen printed electrodes with bacterial photosynthetic reaction centers by laser printing technology for mediatorless herbicide biosensing, Electrochemistry Communications, 2016, 64:46-50.

Das R, Kiley PJ, Segal M, Norville J, Yu AA, Wang LY, Trammell SA, Reddick LE, Kumar R, Stellacci F, Lebedev N, Schnur J, Bruce BD, Zhang SG, Baldo M, Integration of Photosynthetic Protein Molecular Complex in Solid State Electrinic Device, 2004, Nano Lett., 4:1079-1083.

Der A, Valkai S, Fabian L, Ormos P, Ramsden JJ, Wolff EK, Integrated optical switching based on the protein bacteriorhodopsin, Photochem Photobiol, 2007, 83:393-396.

Dimonte A, Frache S, Erokhin V, Piccinini G, Demarchi D, Milano F, De Micheli G, Carrara S, Nanosized optoelectronic devices based on photoactivated proteins, Biomacromolecules, 2012, 13:3503-3509. 
Dorogi M, Bálint Z, Mikó C, Vileno B, Milas M, Hernádi K, Forró L, Váró G, Nagy L, Stabilization effect of single-walled carbon nanotubes on the functioning of photosynthetic reaction centers, J. Phys. Chem. B, 2006, 110:21473-21479.

Estephan E, Saab MB, Agarwal V, Cuisinier FJG, Larroque C, Gergely C, Peptides for the biofunctionalization of silicon for use in optical sensing with porous silicon microcavities. Adv Funct Mater, 2011, 21:2003-2011.

Fábián L, Heiner Z, Mero M, Kiss M, Wolff EK, Ormos P, Osvay K, Dér A, Protein-based ultrafast photonic switching, Opt Express, 2011, 19:18861-18870.

Folkes LK, Wardman P, Oxidative activation of indole-3- acetic acids to cytotoxic species-a potential new role for plant auxins in cancer therapy. Biochem. Pharmacol., 2001, 61:129-136.

Frolov L, Rosenwaks Y, Richter S, Carmeli C, Carmeli I, Photoelectric Junctions Between GaAs and Photosynthetic Reaction Center Protein, J. Phys. Chem. C, 2008, 112(35):13426-13430.

Giardi MT, Pace E, Biotechnological Applications of Photosynthetic Proteins, Biochips, Biosensors and Biodevices, Springer, New York, 2006, pp. 147-154.

Giardi MT, Scognamiglio V, Rea G, Rodio G, Antonacci A, Lambreva M, Pezzotti G, Johanningmeier $\mathrm{U}$, Optical biosensors for environmental monitoring based on computational and biotechnological tools for engineering the photosynthetic D1 protein of Chlamydomonas reinhardtii, Biosens. Bioelectron., 25(2):294-300.

Giraldo JP, Landry MP, Faltermeier SM, McNicholas TP, Iverson NM, Boghossian AA, Reuel NF, Hilmer AJ, Sen F, Brew JA, Stranno M, (2014) Plant nanobionics approach to augment photosynthesis and biochemical sensing, Nat Mater, 2014, 13:400-408. 
Graige MS, Feher G, Okamura MY, Conformational gating of the electron transfer reaction QA.QB --> QAQB-. in bacterial reaction centers of Rhodobacter sphaeroides determined by a driving force assay, Proc. Natl. Acad. Sci. U. S. A., 1998, 95(20):11679-11684.

Govorov AO, Carmeli I, Hybrid Structures Composed of Photosynthetic System and Metal Nanoparticles: Plasmon Enhancement Effect, Nano Lett., 2007, 7:620-625.

Govindjee, Beatty JT, Gest H, Allen JF, 2006, Discoveries in photosynthesis. Advances in photosynthesis and respiration. Springer, Berlin

Greco O, Rossiter S, Kanthou C, Folkes LK, Wardman P, Tozer GM, Dachs GU, Horseradish peroxidase-mediated gene therapy: choice of prodrugs in oxic and anoxic tumor conditions. Mol. Cancer Therapeutics, 2001, 1:151-160.

Guascitoa MR, Chatzipetroub M, Chirizzia D, Trottac M, Massaoutib M, Giottaa L, Milanoc F, Zergiotib I, Modification of Gold Electrodes with Bacterial Reaction Centres Immobilized by Laser Induced Forward Transfer (LIFT) Technique for Amperometric Herbicide Detection, 2016, Biosensors, 27:195-196.

Hajdu K, Gergely C, Martin M, Cloitre T, Zimányi L, Tenger K, Khoroshyy P, Palestino G, Agarwal V, Hernádi K, Németh Z, Nagy L, Porous silicon/photosynthetic reaction center hybrid nanostructure, Langmuir, 2012, 28:11866-11873.

Hajdu K, Gergely C, Martin M, Zimányi L, Agarwal V, Palestino G, Hernádi K, Németh Z, Nagy L, Light-harvesting bio-nanomaterial using porous silicon and photosynthetic reaction center, Nanoscale Research Letters, 2012, 7:400-406.

Hajdu K, Szabó T, Magyar M, Bencsik G, Németh Z, Nagy K, Magrez A, Forró L, Váró G, Hernádi K, Nagy L, Photosynthetic reaction center protein in nanostructures, Phys. Status Solidi B, 2011, 248:2700-2703. 
Hayashi K, Kurita R, Horiuchi T,Niwa O, Microfabricated On-Line Electrochemical Flow Cell Integrated with Small Volume Pre-Reactor for HighlySelectiv e Detection of Biomolecules, Electroanalysis, 2002, 14(5):333-338.

Hollander MJ, Magis JG, Fuchsenberger P, Aartsma TJ, Jones MR, Frese RN., Enhanced Photocurrent Generation by Photosynthetic Bacterial Reaction Centers through Molecular Relays, Light-Harvesting Complexes, and Direct ProteinGold Interactions, Langmuir, 2011, 27(16):10282-10294.

Janovics R. Development of radiocarbon-based measuring methods and their application for nuclear environmental monitoring (PhD thesis, in Hungarian). 2016. University of Debrecen and Hungarian Academy of Sciences Institute for Nuclear Research. https://dea.lib.unideb.hu/dea/handle/2437/217939?locale-attribute=en.

Jianga Y, Zhanga Q, Li F, Niu L, Glucose oxidase and graphene bionanocomposite bridged by ionic liquid unit for glucose biosensing application, Sensors and Actuators B: Chemical, 2012, 161:728-773.

Jones MR, The petite purple photosynthetic powerpack, Biochem. Soc. Trans. 2009, 37:400-407.

Kamran M, Delgado JD, Friebe V, Aartsma TJ, Frese RN, Biomacromolecules, Photosynthetic protein complexes as bio-photovoltaic building blocks retaining a high internal quantum efficiency, Biomacromolecules, 2014, 15:2833-2838.

Kaniber SM, Simmel FC, Holleitner AW, Carmeli I, The optoelectronic properties of a photosystem I-carbon nanotube hybrid system, Nanotechnology, 2009, 20(34):345701.

Krassen H, Schwarze A, Friedrich B, Ataka K, Lenz O, Heberle J, Photosynthetic hydrogen production by a hybrid complex of photosystem I and [NiFe]-hydrogenase, ACS Nano 3, 2009, 3(12):4055-4061. 
Krieg R, Halbhuber KJ, Recent advances in catalytic peroxidase histochemistry. Cellular Mol. Biol., 2003, 49:547-563.

Le Clercq M, Van Der Plicht J, Gröning M, New 14C reference materials with activities of 15 and 50 pMC, Radiocarbon, 1998, 40:295-297.

Lu Y, Xu J, Liu B, Kong J, Photosynthetic reaction center functionalized nano-composite films: Effective strategies for probing and exploiting the photo-induced electron transfer of photosensitive membrane protein, Biosens. Bioelectron., 2007, 22:1173-1185.

Liu J, Zou J, Zhai L, Bottom-up Assembly of Poly(3-hexylthiophene) on Carbon Nanotubes: 2D Building Blocks for Nanoscale Circuits, Macromol Rapid Commun., 2009, 30:1387-1391.

Magyar M, Hajdu K, Szabó T, Endrődi B, Hernádi K, Horváth E, Magrez A, Forró L, Visy C, Nagy L, Sensing hydrogen peroxide by carbon nanotube/horse radish peroxidase bionanocomposite, Phys. Status Solidi B, 2013, 250(12): 2559-2563.

Magyar M, Redox fehérjék bionanokompozitokban, Ph.D. disszertáció, Szegedi Tudományegyetem, 2015.

Magyar M, Hajdu K, Szabo T, Hernadi K, Dombi A, Horvath E, Forro L, Nagy L, Long term stabilization of reaction center protein photochemistry by carbon nanotubes, Phys. Status Solidi B, 2011, 248(11):2454-2457.

Major I, Gyökös B, Túri M, Futó I, Filep Á, Hoffer A, Furu E, Jull AJT, Molnár M, Evaluation of an automated EA-IRMS method for total carbon analysis of atmospheric aerosol at HEKAL. Journal of Atmospheric Chemistry ,2017, 75(1):85-96.

Milano F, Dorogi M, Szebenyi K, Nagy L, Maroti P, Varo G, Giotta L, Agostiano A, Trotta M, Enthalpy/entropy driven activation of the first interquinone electron transfer in bacterial 
photosynthetic reaction centers embedded in vesicles of physiologically important phospholipids, Bioelectrochemistry, 2007, 70(1):18-22.

Molnár M, Rinyu L, Veres M, Seiler M, Wacker L, Synal HA, EnvironMICADAS: A mini 14C AMSwith enhanced gas ion source interface in the Hertelendi Laboratory on Environmental Studies (HEKAL). Radiocarbon, 2013, 55(2):338-44.

Musazadea E, Voloshinb R, Bradyc N, Mondalc J, Atashovaa S, Zharmukhamedovb SK, Huseynovaa I, Ramakrishnae S, Najafpourf MM, Sheng JR, Brucec BD, Allakhverdiev SI, Biohybrid solar cells: Fundamentals, progress, and challenges, 2018, Journal of Photochemistry and Photobiology C: Photochemistry Reviews, 35:134-156.

Nagy L, Kiss V, Brumfeld V, Malkin S, Thermal and structural changes of photosynthetic reaction centers characterized by photoacoustic detection with a broad frequency band hydrophone, Photochem. Photobiol., 2001, 74:81-87.

Nagy L, Milano F, Dorogi M, Trotta M, Laczko G, Szebenyi K, Varo G, Agostiano A, Maroti P, Protein/lipid interaction in the bacterial photosynthetic reaction center: phosphatidylcholine and phosphatidylglycerol modify the free energy levels of the quinones, Biochemistry, 2004, 43:12913-12923.

Nagy L, Hajdu K, Fisher B, Hernádi K, Nagy K, Vincze J, Photosynthetic Reaction Centres from Basic Research to Application Possibilities, Notulae Scientia Biologica, 2010, 2(2): 07-13.

Nakamura C, Hasegawa M, Nakamura N, Miyake J, Rapid and specific detection of herbicides using a self-assembled photosynthetic reaction center from purple bacterium on an SPR chip. Biosens Bioelectron, 2003, 18:599-603. 
Noji T, Kamidaki C, Kawakami K, Shen JR, Kajino T, Fukushima Y, Sekitoh T, Itoh S, Photosynthetic Oxygen Evolution in Mesoporous Silica Material: Adsorption of Photosystem II Reaction Center Complex into 23 nm Nanopores in SBA, Langmuir, 2011, 27:705-713.

Oda I, Hirata K, Watanabe S, Shibata Y, Kajino T, Fukushima Y, Iwai S, Itoh S, Function of Membrane Protein in Silica Nanopores: Incorporation of Photosynthetic Light-Harvesting Protein LH2 into FSM, J. Phys. Chem. B, 2006, 110:1114-1120.

Orsovszki G, Rinyu L, Flame-sealed tube graphitization using zinc as the sole reduction agent: Precision improvement of EnvironMICADAS 14C measurements on graphite targets, Radiocarbon, 2015, 57:979-990.

Ozdokur KV, Demir B, Yavuz E, Ulus F, Ertena C, Aydına I, Demirkol DO, Pelit L, Timur S, Ertas FN, Pyranose oxidase and Pt-MnOx bionanocomposite electrode bridged by ionic liquid for biosensing applications, Sensors and Actuators B: Chemical, 2014, 197:123-128.

Palestino G, Legros R, Agarwal V, Pérez E, Gergely C, Functionalization of nanostructured porous silicon microcavities for glucose oxidase detection. Sens Actuators B, 2008, 135:27-34.

Raymond J, Blankenship RE, The origin of the oxygen-evolving complex,Coord. Chem. Rev., 2008, 252:377-383.

Rinyu, L. A primer kinon energetikai változásai a fotoszintetizáló baktériumok reakciócentrumában: mutáció, késleltetett fluoreszcencia és modell-számítások, Ph.D. disszertáció, Szegedi Tudományegyetem, 2007.

Rinyu L, Molnár M, Major I, Nagy T, Veres M, Kimák Á, Wacker L, Synal HA, Optimization of sealed tube graphitization method for environmental C-14 studies using MICADAS, Nuclear Instruments and Methods in Physics Research B, 2013, 294:270-275. 
Rinyu L, Orsovszki G, Futó I, Veres M, Molnár M, Application of zinc sealed tube graphitization on sub-milligram samples using EnvironMICADAS. Nuclear Instruments and Methods in Physics Research Section B., 2015, 361:406-413.

Scognamiglioa V, Pezzottib I, Pezzottib G, Canob J, Manfredoniab I, Buonaseraa K, Rodiob G, Giardia MT, A new embedded biosensor platform based on micro-electrodes array (MEA) technology, Sensors and Actuators B: Chemical, 2013, 176:275-283.

Sepunaru L, Tsimberov I,. Forolov L, Carmeli C, Carmeli I,. Rosenwaks Y, Picosecond electron transfer from photosynthetic reaction center protein to GaAs, Nano Lett., 2009, 9(7)2751-2755.

Silva MR, Vasconcelos de Sá LR, 1 Carlos Russo, Scio E, Ferreira-Leitão VS, The Use of HRP in Decolorization of Reactive Dyes and Toxicological Evaluation of Their Products, Enzyme Res., 2010, 3:703824.

Song Z, Yuan, R, Chai Y, Zhuo Y, Jiang W, Su H, Che X, Li J, Horseradish peroxidasefunctionalized Pt hollow nanospheres and multiple redox probes as trace labels for a sensitive simultaneous multianalyte electrochemical immunoassay, Chem. Commun. (Camb.), 2010, 46: 6750-6752.

Szabó T, Csekő R, Hajdu K, Nagy K, Orsolya S, Galajda P, Gard G, Nagy L, Sensing photosynthetic herbicides in an electrochemical flow cell, Photosynth Res., 2017, 132(2):127134.

Swainsbury DJK, Friebe VM, Frese RN, Jones MR, Evaluation of a biohybrid photoelectrochemical cell employing the purple bacterial reaction centre as a biosensor for herbicides, 2014, Biosensors and Bioelectronics, 58:712-178.

Synal HA, Döbeli M, Jacob S, Stocker M, Suter M, Radiocabon AMS towards its lower-energy limits, Nuclear Instruments and Methods in Physics Research B., 2004, 223-224:339-345. 
Synal HA, Stocker M, Suter M, MICADAS: A new compact radiocarbon AMS system, Nuclear Instruments and Methods in Physics Research B., 2007, 259:7-13.

Szekeres GP, Nemeth K, Kinka A, Magyar M, Reti B, Controlled nitrogen doping and carboxyl functionalization of multi-walled carbon nanotubes. Phys. Status Solidi B., 2015, 252:2472-2478.

Tan SC, Crouch LI, Jones MR, Welland M, Generation of Alternating Current in Response to Discontinuous Illumination by Photoelectrochemical Cells Based on Photosynthetic Proteins, Angewandte Chemie - International Edition, 2012, 51:6667-6671.

Terasaki N, Yamamoto N, Tamada K, Hattori M, Hiraga T, Tohri A, Sato I, Iwai M, Taguchi S, Enami I, Inoue Y, Yamanoi Y, Yonezawa T, Mizuno K, Murata M, Nishihara H, Yoneyama S, Minakata M, Ohmori T, Sakai M, Fujii M, Bio-photosensor: Cyanobacterial photosystem I coupled with transistor via molecular wire, Biochim. Biophys. Acta, 2007, 1767:653-659.

Tiede DM, Utschig L, Hanson DK, Gallo DM, Resolution of electron and proton transfer events in the electrochromism associated with quinone reduction in bacterial reaction centers, Photosynthesis Research., 1998, 55: 267-273.

Tiede DM, Vázquez J, Córdova J, Marone P, Time-resolved electrochromism associated with the formation of quinone anions in the Rhodobacter sphaeroides R26 reaction center, Biochemistry,1996, 35:10763-10775.

Veitch NC, Horseradish peroxidase: a modern view of a classic enzyme, Phytochemistry, 2004, 65:249-259.

Ventrella A, Catucci L, Agostiano A, Herbicides affect fluorescence and electron transfer activity of spinach chloroplasts, thylakoid membranes and isolated Photosystem II, Bioelectrochemistry, 2010, 79:43-49. 
Vothknecht UC, Westhoff P, Biogenesis and origin of thylakoidmembranes, Biochim. Biophys. Acta Mol. Cell Res., 2001:91-101.

Vsevolodov N, 1998, Biomolecular electronics. Birkhauser, Boston.

Wacker L, Christl M, Synal HA, Bats: A new tool for AMS data reduction, Nuclear Instruments and Methods in Physics Research Section B: Beam Interactions with Materials and Atoms, 2010, 268:976-979.

Wardman P, Indole-3-acetic acids and horseradish peroxidase:A new prodrug/enzyme combination for targeted cancer therapy,Current Pharmaceutical Design, 2002, 8:1363-1374.

Wraight CA, Clayton R, The absolute quantum efficiency of bacteriochlorophyll photooxidation in reaction centres of Rhodopseudomonas spheroides," Biochimica et Biophysica Acta (BBA) Bioenergetics, 1974, 333:246-260.

Yadav RM, Shripathi T, Srivastava A, Srivastava ON, Effect of ferrocene concentration on the synthesis of bamboo-shaped carbon-nitrogen nanotube bundles. J Nanosci Nanotechnol, 2005, 5:820-824.

Zhao J, Zou Y, Liu B, Xu C, Kong J, Differentiating the orientations of photosynthetic reaction centers on Au electrodes linked by different bifunctional reagents, Biosensor Bioelectron., 2002, 17:711-718. 


\section{Summary}

During my research work I prepared protein based bionanocomposit materials from bacterial photosynthetic reaction center protein (RC) and horseradish peroxidase enzyme (HRP) with inorganic carrier materials (indium-tin-oxide, doped or undoped carbon nanotube and conducting polymers) and characterized the structural, spectroscopical, electrochemical properties.

RCs were fixed to the surface of ITO by drying method and I measured the conductivity change of the system in the function of the RC concentration. I observed that the conductivity change shows saturation when the surface is covered by RC monolayer. In case of higher concentration the conductivity change is caused by the heat dissipation of the absorbed light energy. The conductivity change in this phase fits well with the one measured for the ITO covered by the photochemically inactive $\mathrm{BChl}$ as a control experiment. The sensitivity of the measurement is very good, some pM RC cause measurable conductivity change.

I showed that as well, the RC protein keep the activity under dried condition and able to generate light induced photocurrent. I prepared an optoelectronic device used ITO and silver electrodes with conducting polymer (PEDOT:PSS (poly(3,4-ethylene-dioxythiophene):poly(styrenesulfonate)) and P3HT (poly-(3-hexyl-thiophene))) layer structure between it. P3HT fibers were grown on the surface of MWCNTs and RCs were built in to the P3HT structure. The active contribution of the RC in the increased photovoltage confirmed by selective light excitation. We can conclude that although the composite has relatively large absorption in the green spectral range, the absolute value of the photovoltage with green light illumination is smaller than the one measured with red light. In addition, the ratio of photovoltage measured for sensitised and non-sensitised sample is smaller for green light than red light (1.3 vs. 2.1).

I investigated the RC based composite materials under wet condition as well, in an electrochemical cell. The ITO/MWCNT/RC, the platinum and the $\mathrm{Ag} / \mathrm{AgCl}$ electrodes were used as working, counter and reference electrode respectively. When I used $0.1 \mathrm{M} \mathrm{NaCl}$ as an electrolyte in the system (high ionic strength) the measured photocurrent was only $0.3 \mu \mathrm{A}$ under light excitation. The added ferrocene mediator has not got any effect on the system, but UQ0 increases it to $1 \mu \mathrm{A}$. If $\mathrm{NaCl}$ was not added (low ionic strength), and the reaction mixture 
contained only TRIS (20 mM, pH 7.0) and the mediators according to the measurement protocol, I measured a small effect of the ferrocene addition and considerable shortening in the current rising time. The result of this measurement confirms that after binding to the electrode the RC keeps its photochemical activity and the donor and acceptor sites remain accessible to the mediators. The accessibility of the donor site is affected by the ionic strength of the solution.

The measured photocurrent increased toward if I used PTAA conducting polymer as a crosslinker instead of EDC/NHS. The PTAA behaves not only as a crosslinker, but it can help the electron transfer between the protein and the electrode material. In this case under the same measuring protocol the measured photocurrent was $7 \mu \mathrm{A}$. This result is almost one order of magnitude higher then the EDC/NHS method.

I determined the isotope content of the applied carbon nanotubes. In case of doped nanotubes the nitrogen and the sulfur content was also determined, which change significantly the physical properties of the MWNTs.

The ratio of the different components of the nanocomposit material is an important parameter, but the determination is not so easy. In order to find out it I used mass spectrometry, based on radiocarbon measurement. If the $14 \mathrm{C}$ content of the components significantly different, the ratio of the components are calculable. The RC content of the RC/MWCNT composite was $53 \mathrm{wt} \%$.

I did similar mass spectroscopy measurement with HRP/MWCNT bionanocomposite, and in in this composite the determined protein content was $72 \mathrm{wt} \%$. 